
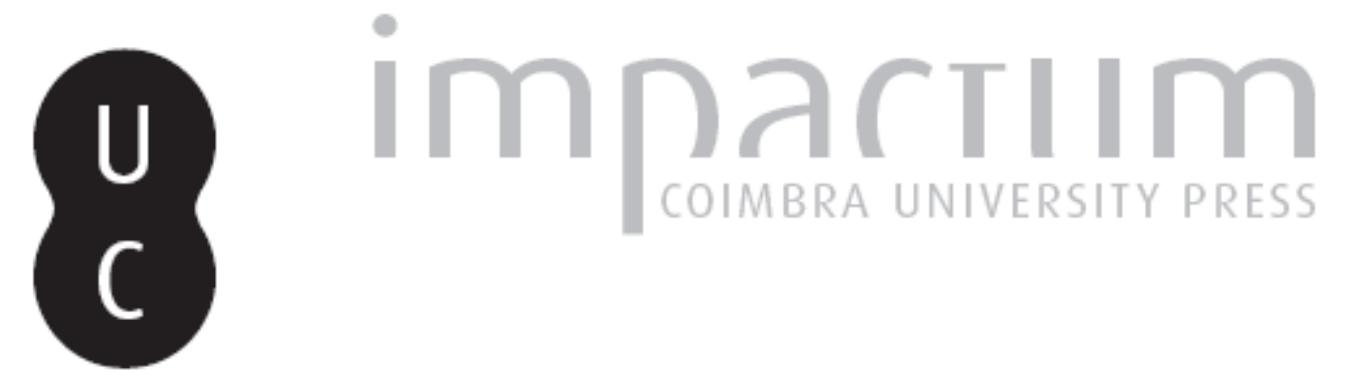

\title{
Inscrições romanas do Museu Municipal de Torres Vedras
}

Autor(es): $\quad$ Mantas, Vasco Gil

Publicado por: Imprensa da Universidade de Coimbra

URL persistente:

URI:http://hdl.handle.net/10316.2/45702

DOI:

DOI:https://dx.doi.org/10.14195/1647-8657_21_1

Accessed : $\quad$ 26-Apr-2023 10:58:52

A navegação consulta e descarregamento dos títulos inseridos nas Bibliotecas Digitais UC Digitalis, UC Pombalina e UC Impactum, pressupõem a aceitação plena e sem reservas dos Termos e Condições de Uso destas Bibliotecas Digitais, disponíveis em https://digitalis.uc.pt/pt-pt/termos.

Conforme exposto nos referidos Termos e Condições de Uso, o descarregamento de títulos de acesso restrito requer uma licença válida de autorização devendo o utilizador aceder ao(s) documento(s) a partir de um endereço de IP da instituição detentora da supramencionada licença.

Ao utilizador é apenas permitido o descarregamento para uso pessoal, pelo que o emprego do(s) título(s) descarregado(s) para outro fim, designadamente comercial, carece de autorização do respetivo autor ou editor da obra.

Na medida em que todas as obras da UC Digitalis se encontram protegidas pelo Código do Direito de Autor e Direitos Conexos e demais legislação aplicável, toda a cópia, parcial ou total, deste documento, nos casos em que é legalmente admitida, deverá conter ou fazer-se acompanhar por este aviso. 
FACULDADE DE LETRAS

INSTITUTO DE ARQUEOLOGIA

\section{CONIMBRIGA}

VOLUMEXXI

UNIVERSIDADE DE COIMBRA

1982 
VASCo Gil Mantas

Assistente da Faculdade de Letras de Coimbra

INSCRIÇÕES ROMANAS DO MUSEU MUNICIPAL DE TORRES VEDRAS

Conimbriga, XXI (1982), 5-99

SUMÁRIO: O autor publica treze inscrições funerárias romanas conservadas no Museu Municipal de Torres Vedras. O conjunto, insuficientemente estudado até à data e que inclui uma inscrição inédita (n. ${ }^{\circ}$ 6), provém de achados fortuitos verificados na cidade e na região, onde são numerosos os vestigios romanos. Tipologicamente muito variadas, as epígrafes do Museu permitem compreender melhor o processo regional da romanização, especialmente entre os séculos $\mathrm{i}$ e iii, realçando quer a existência de um estrato populacional indígena pouco romanizado, conservador, quer a presença de um importante grupo directa ou indirectamente relacionado com a colonização romana e reflectindo a proximidade de Olisipo (sete referências à tribo Galéria e doze denominações através dos tria nomina).

RÉS U MÉ： L'auteur publie treize inscriptions funéraires romaines, conservées au Musée Municipal de Torres Vedras. L'ensemble, insuffisamment étudié jusqu'à ce jour et comportant un document inédit (n. $\left.{ }^{\circ} 6\right)$, provient de trouvailles fortuites, faites dans la ville et dans la région, où les vestiges romains sont nombreux. Ces inscriptions très variées permettent de mieux comprendre le processus régional de la romanisation, spécialement entre les Ier et HÙme siècles, en mettant en relief tantôt l'existence d'une couche de population indigène, peu romanisée et conservatrice, tantôt la présence $d$ un groupe important, en relation plus ou moins directe avec la colonisation romaine et reflétant la proximité d'Olisipo (on dénombre sept références à la tribu Galeria et douze dénominations par tria nomina). 
(Página deixada propositadamente em branco) 


\title{
INSCRIÇÕES ROMANAS DO MUSEU MUNICIPAL DE TORRES YEDRAS
}

\author{
O Museu Municipal de Torres Yedras, fundado em 1929 e \\ actualmente instalado no edifício oitocentista da Misericórdia, \\ conserva, entre as suas colecções arqueológicas, um interessante \\ conjunto epigráfico constituído por treze inscrições funerárias \\ romanas $\left({ }^{1}\right)$. Tais inscrições, provenientes, com uma unica excepção,
}

(*) A bibliografia em que se referem as inscrições de que trata este estudo é considerável: ANDré de ReSEnde, Codex Valentianus, (ms. extraviado. Évora, 1550?); J. S Trada, C. Julii Caesaris rerum gestarum Commentarios, Francoforte, 1575 (anexo); J. Gruter, Thesaurus Inscriptiones, Heidelberga, 1601; L. Marinho de Azevedo, Primeira Parte da Fundação, Grandeza e Antiguidade da mui insigne cidade de Lisboa, Lisboa, 1652; A. Muratori, Novus Thesaurus veterum inscriptionum, in praecipuis earundem collectionibus praetermissarum, Milão, 1740; V. S ALGa Do, Collecção dos Monumentos Romanos descobertos em Portugal, e extrahidos de varios autores e da curiosidade do collector o R. P. Fr. Vicente Salgado, no ano de 1796 (ms. n. ${ }^{\circ} 592$ da Biblioteca da Academia das Ciências de Lisboa); Levy Maria Jordão, Portugaliae Inscriptiones Romanas, Lisboa, 1859; M. MadeIra Torres, Descripção Historica e Economica da Villa e Termo de Torres Vedras, Coimbra, $1861^{2}$ (edição anotada por J. da Gama Leal e por J. de Faro e Vasconcelos); E. HÜBNER, Corpus Inscriptionum Latinarum, II, Inscriptiones Hispaniae Latinae; Supplementum, Berlim, 1869, 1892 ( - CIL II); Pinho Leal, Portugal Antigo e Moderno, I, IX, Lisboa, 1873, 1880; J. Vieira, Torres Vedras Antiga e Moderna, Torres Vedras, 1926; A. Ricardo Belo, Nótulas sobre arqueologia de Torres Vedras e seu termo. Epigrafia luso-romana, «Badaladas», 48, 49, 50, 51, 56, 57, 62,1952; 77, 85,1953; 98, 101, 1954; 138, 1955; 143, 144,146, 1956; 230, 1959 ( = Belo, «Baladadas»); A. Ricardo Belo, Símbolos astrais das lápides luso-romanas, Lisboa, 1959 ( = BELo, Símbolos); Notícias, «Conimbriga», I, 1959, p. 157; Grande Enciclopédia Portuguesa e Rrasileira, XXXII, Lisboa, $1960(=G E P B) \mid$ J. Mendes de Almeida/F. Bandeira Ferre I RA, Varia Epigraphica, «Revista de Guimarães», LXXVI, 3-4, 1966,

Conimbriga, 21 (1982), 5-99 
de Torres Vedras e do seu termo (mapa I), situado numa das zonas lusitanas de maior riqueza epigráfica $\left(^{2}\right)$, representam percentagem importante das epígrafes romanas encontradas na região e permitem entrever o processo regional de romanização, processo decerto positivamente influenciado pela proximidade de Olisipo e pela fertilidade natural dos amplos vales e suaves colinas dos campos torresãos.

O concelho de Torres Vedras é particularmente abundante em vestígios representativos de uma intensa ocupação humana que se estende da Pré-História aos nossos dias: a fortificação miliarense do Zambujal, contemporânea dos primeiros metalurgistas peninsulares, e o forte de S. Vicente, um dos mais importantes do complexo defensivo das Linhas de Torres, constituem significativas balizas de uma história prestigiosa e movimentada, cujas nebulosas fases primitivas só a arqueologia permite esclarecer.

Pouco sabemos acerca das populações locais pré-romanas: os Túrdulos, oriundos da bacia do Guadalquivir, terão emigrado, cerca do século ui a.C., para o litoral entre o Tejo e o Mondego, onde ocupariam os oppid.a globalmente referidos por Estrabão( $\left.{ }^{3}\right)$; topónimos como Runa e Turcifal apontam para a coexistência de elementos linguísticos indo-europeus com outros bastante exóticos $\left({ }^{4}\right)$, fenómeno a que alude Tovar em relação às divindades do Ocidente peninsulari5 ${ }^{5}$. As forças de Décimo Junio Bruto devem ter atingido a região em 138 a.C., quando o cônsul

p. 341-343 ( = Mendes de Almeida/Bandeira Ferreira, Varia); J. Vives, Inscripciones Latinas de la España Romana, I-II, Barcelona, 1971, 1972 ( - ILER). Outras fontes abreviadas: Prosopographia Imperii Romani, Berlim-Lípsia ( = PIR); Hispania Antigua Epigraphica, Madrid (=IiAE) ; G. Alföldy, Die Römischen Inschriften von Tarraco, I-II, Berlim, 1975 ( = RIT); R. Hurtado de San Antonio, Corpus Provincial de Inscripciones Latinas, Cáceres, 1977 ( = CPIL).

(2) J. Untermann, Elementos de un Atlas Antroponimico de la Hispania Antigua, Madrid, 1965, p. 18, mapa B.

(3) Estrabĩo, II, 3, 5.

(4) A linguística considera o elemento turgi=turci como uma formação ibérica, derivada da base toponímica *ur, pertencente ao substracto mais profundo.

${ }^{5}$ ) A. Tovar, Les noms ibériques, "Actes du Colloque International sur l'Onomastique Latine», Paris, 1977, p. 288 (= Tov a R, Actes $)$.

Conimbriga, 21 (1982), 5-99 
estabeleceu uma das suas bases principais em Olisipo. Mais tarde, no sector ¡mediatamente a norte de Torres Vedras, o grande tesouro de denários encontrado em Columbeira (Bombarral) reflecte perturbações relacionadas com o episodio sertoriano (b) ; a fase final da campanha de Júlio César contra os Lusitanos teve lugar precisamente nessa mesma zona.

Os vestigios arqueológicos da ocupação romana são muito numerosos e a sua distribuição permite, eventualmente, traçar um esboço da rede viària regional. Uma parte desses vestígios, remanescentes de antigas villcte, se não também de atesta uma importante implantação rural durante todo o período romano. A Quinta de S. Gião e a povoação de Penedo forneceram os materiais mais interessantes até agora recuperados. As invasões germânicas não terão alterado profundamente a estrutura económica e social da região, tanto mais que Lisboa se manteve como grande cidade comercial e portuária $\left.{ }^{(}\right)$. Infelizmente, as características agrícolas da zona não facilitam as escavações e a publicação dos materiais nela recolhidos é parca.

Os monumentos epigráficos de que nos ocupamos neste artigo, embora não se encontrem inéditos, exceptuando o $\mathrm{n} .^{\circ} 6$, constituem um exemplo flagrante da necessidade imperiosa de rever e completar o CIL II, problema regularmente debatido mas ainda não resolvido $\left({ }^{9}\right)$. Com efeito, das treze inscrições recolhidas no Museu, Hübner publicou apenas cinco (CIL II 261, 269, 280, 308, 321), precisamente as mesmas que J. Vives incluiu na sua antologia (ILER 5550, 3623, 6339, 6171, 4749), facto que nos pareceu suficientemente significativo para justificar este trabalho, visto que o recurso à epigrafia permanece como um dos mais importantes meios de recuperar múltiplos aspectos da obliterada história da Lusitânia romana.

$\left(^{6}\right)$ Mário hipólito, Dos tesouros de moedas romanas em, Portugal, «Conimbriga», II-III, 1960-1961, p. 75-77.

$\left(^{7}\right)$ E. Hü Bner, Noticias Archeologicas de Portugal, Lisboa, 1871, p. 14 ( = HÜ̈nER, Noticias).

(8) L. Garcia Moreno, Colonias de comerciantes orientales en la Peninsula Ibérica. S. V-VII, «Habis», 3, 1973, p. 148-149.

(9) R. Étienne, Le Centre Pierre Paris et la révision des inscriptions grecques et latines de la Péninsule Ibérique, «Conimbriga», X $\backslash$, 1977, p. 83-88. 
1 - S. GIÃO. Fotos 1 e 2

a) Descrição

Cupa de calcário lioz, arciforme e monolítica, encontrada em 1931 perto da antiga ermida de S. Gião, freguesia de Santa Maria, Torres Vedras. Quase intacta, desprovida de conduta para libações, é moldurada junto à base, lateralmente, por um escapo. O campo epigráfico ocupa, sem qualquer ornato, toda a superficie de urna das extremidades. Na zona de Torres Vedras foi registado outro monumento idêntico: descoberto na Praia de Santa Cruz, conserva-se em Lisboa, no Museu Nacional de Arqueologia e Etnologia $\left({ }^{10}\right)$.

Dimensões: 88x44x37. Campo epigráfico: 44x37.

IVLIA . L (ucii) . F (ilia) . AMOE/NA . AN (norum) . XII .

$\mathrm{H}($ íç) . S (ita) . E \{st) ! MA (ter) . D(e) . S (uo) . F (ecit)

Júlia. Amena, filha de Lúcio, de doze anos de idade, está aqui sepultada. A mâe mandou fazer à sua custa (este monumento).

Altuia das letras: 4,7. Espaços: 1:12; 2:0,8; 3:0,8; 4:9.

b) Bibliografia, e variantes

BELO, «Badaladas», 62, 1952 (desenho).

1. 1: BELO omite a indicação do ponto final.

1. 3: M.D.S.F. (BELO).

c) Comentário

A paginação, apesar do recurso ao traçado de um eixo vertical e de linhas auxiliares, não visíveis, é medíocre: a fórmula final foi

$\left({ }^{10}\right)$ F. Alves Pereira, Tampa de sepultura da época $* \bullet \ll o m a n a,<<0$ Archeologo Português», XIV, 1909, p. 261-265. 
inscrita numa posição excêntrica e o cognome, cortado. $O$ ductus é, com algumas incertezas, regular. A pontuação, correcta, consta de sinais pequenos, circulares. Os caracteres, verticalmente alongados, são do tipo monumental e denunciam uma fase, não muito recuada, da chamada boa época: a incisão é triangular, de abertura variável mas nítida; o $\mathrm{A}$ difere nas 1.1 e 2 ; barras do $\mathrm{E}$ e do $\mathrm{F}$ idênticas, e, como a do L, curtas; o $\mathrm{M}$ é aberto e o X, desajeitadamente afastado do algarismo seguinte, na 1.2 , é do tipo cursivo. A qualidade do desenho do $\mathrm{S}$ é má: forma semelhante ocorre, por exemplo, numa inscrição da necrópole alentejana de Camugemí1 $^{11}$ ). O D aparenta uma forma vulgar no século II. Finalmente, o solitário nexo MA, cuja leitura escapou a Ricardo Belo, é dos mais frequentes da epigrafia latina.

O prestigioso gertilício registado na epígrafe ocupa o primeiro lugar entre os mais documentados da Hispânia, atingindo notável concentração no município olisiponense $\left({ }^{12}\right)$. A sua grande difusão na Lusitânia ficou a dever-se, fundamentalmente, a liberalidades de Césai e de Augusto, os quais agregaram à gens lulia uma multidão de famílias de origem étnica e social diversa. Amoenus, $a$ é um cognome latino cuja frequência na região lusitana entre o Tejo e o Douro, muito especialmente na área de Lisboa, contrasta de forma evidente com a sua extrema raridade nas restantes regiões da Península (13). Kajanto situa-o no grupo dos cognomina alusivos a condições espirituais e destaca o estatuto livre de metade das mulheres que o utilizaram na Hispânia (14). Segundo hipótese enunciada por M. L. Albertos $\left({ }^{15}\right)$, a expansão deste cognome terá sido facilitada por uma eventual concordância de sentido com um nome indígena, tal como parece indiscutível em relação a Maternus

(u) J OSÉ D’ EN CARNAÇão, Inscriptions mal connues du Conventus Pacensis «Conimbriga», XVI, 1977, p. 50-51, n. ${ }^{\circ}$ 3, pl. 3 ( = ENCarnaÇão, Inscriptions).

$\left.{ }^{12}\right)$ R. KNAPP, The Origins of Provincial Prosopography in the West, «Ancient Society», 9, 1978, p. 199-200, 214.

(13) UntermanN, p. 55-56, mapa 8.

(14) I. Kajanto, The Latin Cognomina, Helsínquia, 1965, p. 64, 282 ( = KaJanto, Cognomina $)$.

(15) M. L. Albertos, Nuevos antropónimos hispánicos, «Emerita», XXXII, 2, 1964, p. 219 (= Alb e r tos, Antropónimos). 
e a Paternus $\left({ }^{16}\right)$. O esquema onomástico presente na cupa de S. Giáo reflecte, com as simplificações inerentes à condição feminina, o princípio estabelecido pela Lex Iulia Municipalis, tal como era

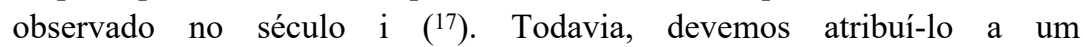
ambiente de indígenas romanizados, suposição sugerida pela hipótese linguística cilada, reforçada pelas características da distribuição geográfica do cognome e pelo seu repetido registo unido a formas de antroponimia indígena, e plenamente confirmada por outra epígrafe com a mesma origem (CIL II 296), levada para França no século $\operatorname{xix}\left({ }^{18}\right)$ : trata-se de uma tabella que, segundo Resende, se encontrava «aa janella da casa que esta junto a S. Gian dantre as vinhas de Torres vedras» e cujo texto - Iulia . C . $f$. Ton/ceta . ami. XX/h.s.e. Iulia . L .f. / Amoena . mater / f. cdestaca, exemplarmente, não só a inserção do cognome em causa num meio indígena fortemente romanizado como também a persistência da antroponimia pré-latina, sob a forma de cognomina, entre os indivíduos de sexo feminino $\left({ }^{19}\right)$. $\mathrm{O}$ duplo testemunho da Quinta de S. Gião revela-se, assim, significativamente elucidativo. As Amenas da gens Iulia, ressalvando um testemunho incerto proveniente dos arredores de Tarragona (RIT 914), ocorrem exclusivamente na Lusitânia Ocidental: concentradas na região de Lisboa, não se lhes conhecem mais de quatro representantes dispersas pelo restante território da província (anexo I). A forma masculina correspondente foi registada uma única vez, em Mérida: I) . $M . S \cdot / L$. lidio Amoeno / ann. XXIIII / h.s.e.s.t.t.l. / ¿Cassia Amoena / filio piissimo / fecit (ILER 4246). Lima inscrição anforária do Testaccio, datada de meados do século ii, parece referir um mercator denominado C. lulius Amoenus ${ }^{(20)}$.

(16) UntermanN, p. 142-143, mapa 59; p. 144-145, mapa 59 bis.

(17) R. Cagna t, Cours d'Épigraphie Latine, Paris, 1914, p. 37-38, 296.

(18) BELO, «Badaladas», 66, 1952.

(19) M. L. Al в E r tos, La mujer hispanorromana a través de la epigrafía, «Revista de la Universidad Complutense», XXVI, 109, 1977, p. 183-184; J. P. Rey-Coquais, Onomastique et histoire de la Syrie gréco-romaine, "Actes $\mathrm{du}$ VII ${ }^{\mathrm{e}}$ Congrès Internationale d'Épigraphie Grecque et Latine», Bucareste-Paris, 1979, p. 177.

${ }^{(20)}$ E. Rodriguez Almeida, Monte Testaccio: I mercatores delVolio della Letica, «Mélanges de l'École Française de Rome (Antiquité)», 91, 1979, 2 , p. 889.

Conimbriga, 21 (1982), 5-99 
As fórmulas finais expressas na epígrafe são normais e encontram-se copiosamente documentadas.

O estudo das cupae $\left({ }^{21}\right)$, monumentos funerários parcialmente relacionados com a prática da incineração e aos quais I. Berciu e W. Wolski atribuem, de forma convincente, significado oikomorpho (22), suscita problemas de difícil solução. As cupae constituem uma série tipologicamente coerente, mas variada, representada em várias regiões do Império Romano (23), sendo muito numerosas na Hispânia (24). Na Lusitânia predominam dois tipos: os monumentos em forma de meio cilindro, como o de S. Gião, encontram-se fracamente representados no Algarve (2õ) e na Beira Litoral (26), atingindo concentrações invulgares em Mérida $\left({ }^{27}\right)$ e na

(21) E. Fernique, Dictionaire des Antiquités Grecques et Romaines, I, 2, Paris, 1908, p. 1594-1595; A. Meille t, Dictionaire Étymologique de la Langue Latine, Paris, $1959^{4}$, p. 158.

(22) I. BERCIU/W. WolsKI, Un nouveau type de tombe mis à jour à Apulum et le problème des sarcophages à vô̂te de VEmpire romain, «Latomus», XXIX, 4, 1970, p. 927-932, 962 (= Bercid/Wolski, Apulum); J. A. Aвásolo/ /M. L. Albertos/J. C. Elorza, Los monumentos funerarios de epoca romana, en forma de casa, de la region de Poza de la Sal, Burgos, 197o, p. 82-83. São particularmente elucidativos os testemunhos contidos em: J. KUBINSKA, Les monuments funéraires dans les inscriptions grecques de VAsie Mineure, Varsóvia, 1968, p. 94-99, pi. XVI; A. BeschaOuCh/R. HANOUne/Y. Thébert, Les ruines de Bulla Regia, Roma, 1977, p. 117, fig. 118.

(23) Berciu-Wolski, Apulum, p. 944-961, fig. 21.

(24) Dolores Julia, Les monuments funéraires en forme de demi-cylindre dans la province romaine de Tarragonaise, «Mélanges de la Casa de Velasquez», I, 1965, p. 29-30, pi. XIX ( = Julia, Monuments)', Berciu/Wolski, Apulum, p. 936.

(25) S. La m в r N o, Catalogue des inscriptions latines du Musée Leite de Vasconcelos, «O Arqueólogo Português», 2. a série, IV, 1962, p. 298, n. ${ }^{\circ} 16$, p. 290, n. $^{\circ} 17$, p. 291, n. ${ }^{\circ} 19$, p. 292, n. $^{\circ} 20$, p. 295, n. $^{\circ} 25$.

(26) V. Correia, Dois monumentos sepulcrais romanos, «O Archeologo Português», XIX, 1914, p. 200-216; M. L. RoDrigues, Inscrições romanas do Museu Machado de Castro, «Humanitas», XI-XII, 1959-1960, p. 112-132, n. ${ }^{\circ}$ 2, 5, 6, 7, 13, 18 (a classificação de uma parte dos monumentos eminienses como cupae parece-nos duvidosa); R. Étienne/G. FABRE/P. e M. LÉvêQue, Épigraphie et Sculpture, Paris, 1977, (Fouilles de Conimbriga, II), p. 53-54, n. ${ }^{\circ} 26$, pi. VIII $[=$ Fouilles $)$.

(27) M. B. Galán, Las necropolis de Merida. Las cupae emeritenses, «Actas del Bimilenario de Merida», Madrid, 1976, p. 149-150, lám. LXIIb. 
região de Lisboa $\left.{ }^{28}\right)$; no Alentejo, nomeadamente na área de Beja $\left({ }^{29}\right)$, são vulgares as cupae em forma de meio tonel, incluindo, não poucas vezes, representações realistas das aduelas e das tampas, tipo também registado na Sardenha ${ }^{(30)}$. A interpretação proposta por Bercio e Wolski parece-nos razão suficiente paia considerarmos distintos os monumentos do grupo alentejano, embora reconhecendo a comodidade da designação geralmente aplicada às pedras cupiformes e arciformes.

Segundo parece, o túmulo de cobertura semicilíndrica penetrou na Península durante o século i e por intermédio da Africa do Norte: as numerosas analogias verificadas, as intensas e tradicionais relações entre as duas regiões da Romania, a distribuição geográfica dos testemunhos, prioritariamente relacionados com grandes centros comerciais e administrativos, tudo aponta francamente nesse sentido ( $\left.{ }^{31}\right)$. Contudo, quando considerada como solução global visando explicar a origem das cupae e não apenas a sua difusão, a hipótese africana resulta incompleta, senão incorrecta. As cupae de pedra hispânicas constituem um grupo específico quase sem representação fora da Península ( $\left.{ }^{32}\right)$, muito provavelmente resultante de influências asiáticas, lícias segundo Berciu e

(28) J. Fontes, Museu Arqueológico de S. Miguel de Odrinhas, Sintra, 1970², p. 14-16, 36-42; José D'ENCARNaÇ̂̃o, Inscrições romanas de Cascais, «Boletim do Museu-Biblioteca do Conde de Castro Guimarães», 2, 1971, p. 89-112, n. ${ }^{\circ}$ 2, 3, 4, 7, 8 ( = Encarnação, Cascais); J. C. Ribeiro, Três novos monumentos de época romana pertencentes à zona oeste do município olisiponense, «O Arqueólogo Português», 3. ${ }^{\mathrm{a}}$ série, VII-IX, 1974-1977, p. 277-329.

(29) A ве L Viana, Museu Regional de Beja. Catálogo da Secção Lapidar, Beja, 1946, p. 5-59, n. ${ }^{\circ}$ 14-26, 52, 55, 62, 64, 68, 70; Aвеl Viana, Notas históricas, arqueológicas e etnográficas do Baixo Alentejo, «Arquivo de Beja», XII, 1955, p. 7 ( = VIANA, Notas).

(30) J. Leite de Vasconcelos, Religiões da Lusitânia, III, Lisboa, 1913, p. 402-403, 405, fig. 175 (= LeITE DE VASCONCELOS, Religióes).

(31) Juliá, Monuments, p. 48-54, pi. XIX; I. Berciu/W. Wolski, Contribution au problème des tombes romaines à dispositif pour les libations funéraires, «Latomus», XXXII, 2, 1973, p. 375 ( = Berciu/Wolski, Contribution); GaLÁ N, p. 151-153.

(3a) $\mathrm{Na}$ necrópole romana do Monte das Oliveiras, ern Jerusalém: Berciu/Wolski, Apulum, p. 964-965; em Bulla Regia, na Tunísia: Beschauoch/Hanoune/Thébert, p. 117-119.

Conimbriga, 21 (1982), 5-99 
Wolski(33). Tais influências, embora pouco explícitas na Lusitânia, encontram-se patentes no material arqueológico ( ${ }^{34}$ ) e foram suficientemente fortes para determinarem a construção do grande monumento funerario de Zalamea ${ }^{35}$ ) e para transparecerem, mais tarde, nas tarifas do Édito do Máximo ( $\left.{ }^{36}\right)$. Não podemos esquecer, também, a aparente origem oriental da maioria dos libertos $\left({ }^{37}\right)$, a quem conjuntamente com os escravos se têm atribuído as cupae ( $\left.{ }^{38}\right)$. Todavia o rigor desta atribuição é, na província lusitana, social e etnicamente relativo : na Herdade da Salsa (Serpa), por exemplo, encontra-se uma cupa cuja epígrafe alude à mulher de um senador $\left({ }^{39}\right)$; os numerosos monumentos reunidos em S. Miguel de Odrinhas apenas facultaram uma inscrição referindo directamente libertos $\left({ }^{40}\right)$; a origem indígena confirmada no caso das duas Amenas de S. Gião, estende-se, sem dúvida, a um grupo de dimensões bem mais vastas do que Dolores Juliá supôs quando analisou os túmulos arciformes da região lisboeta ( $\left.{ }^{41}\right)$. Quanto à hipótese de uma possível influência itálica sobre as çupae hispânicas, sugerida por G. Fabre ( $\left.{ }^{42}\right)$, não parece aplicável à Lusitânia, atendendo à cronologia relativamente baixa dos monumentos italianos. Resta o problema do sentido religioso das

(33) Berciu/Wolski, Apulum, p. 950-953, 962; R. Garter, The Submerged Seaport of Aperlae [Turkey), «The International Journal of Nautical xVrchaeology», VII, 3, 1978, p. 184, ñg. 8.

(34) Jorge de Alarcão, Portugal Romano, Lisboa, 1973; p. 151-152 ( = ALARC Ão, Portugal).

(35) A. Garcia y Bellido, El monumento funerario de Zalamea de la Serena, la antigua lulipa, «Noticiario Arqueológico Hispánico», V, 1962, p.237-240 (= GARCIA Y BELlido, Zalamea).

(36) M. Giacchero, Edictum Diocletiani et Collegarum de pretiis rerum venalium in integrum restitutum e latinis graecisque fragmentis, I, Génova, 1974, p. 310 .

(37) P. Petit, La Paix Romaine, Paris, 1967, p. 285-286.

(38) Julí, Monuments, p. 45-46; Berciu-Wolski, Contribution, p. 375.

(39) Vi an A, Notas, XII, 1955, p. 5-7, est. I, 5.

(40) M. CAR dozo, Catálogo das inscrições lapidares do Museu Arqueológico de S. Miguel de Odrinhas, Sintra, 1956, p. 63-64, n. ${ }^{\circ}$ XVI ( = Cardozo, Catálogo).

(41) Juliá, Monuments, p. 48.

(42) G., FABRE, Un affranchi impérial à Conimbriga: P. Aelius Ianuarius, «Revuedes Études Anciennes», LXXV, 1-2, 1973, p. 113-114. 
cupae: as teorias enunciadas por Leite de Vasconcelos (43), W. Deonna $\left({ }^{44}\right)$, S. Lambrino $\left({ }^{45}\right)$ e J. M. Blázquez $\left({ }^{46}\right)$, embora aliciantes, não o resolveram.

Atendendo aos factos realmente conhecidos - como a relevante onomástica africana e oriental registada nas epígrafes - uma análise seguia da problemática proposta pelas cupae hispânicas parece-nos implicar o reconhecimento de uma dupla influência asiática e africana $\left({ }^{47}\right)$, influência cuja origem relacionamos concretamente com a conquista da Mauritania, assim como um cuidadoso exame dos monumentos cupiformes do grupo alentejano, posteriores aos da região de Lisboa e evidentemente diferentes não obstante as confusões complacentes da terminologia (CIL II 6178).

A Quinta de S. Gião, situada nos arredores ocidentais de Torres Vedras, perto do Sizandro, ocupa o local de uma importante villa romana. Entre os vestígios encontrados dispersos no local e que foi possível recolher no Museu, destacam-se duas lucernas de bronze, a base e o coroamento de uma ( ?) grande ara e a cupa de lulia Amoena. Na estrutura da ermida de S. Gião, pequeno templo várias vezes reconstruído e presentemente arruinado, foram reutilizados numerosos materiais antigos, entre os quais pelo menos três inscrições $\left(\mathrm{n}^{\circ} 2=C I L\right.$ II $280 ;$ n. ${ }^{\circ} 3-C I L$ II 269; CIL II 296).

\section{d) Dataçâo}

A ausência de fórmula funerária inicial, o uso do nominativo, a indicação da idade, a expressão simples dos laços familiares e

(43) Leite de Vasconcelos, Religiões, III, 1913, p. 401-405.

(44) \y Deonna, Quand dieu roule ses tonneaux, «Genava», XXIV, 1946, p. 120.

(4õ) S. Lambrino, Le dieu lusitanien Endovellicus, «Bulletin des Etudes Portugaises», XV, 1951, p. 129-132.

(46) J. M. Blazquez, Religiones Primitivas de Hispania, I, Roma-Madrid, 1963, p. 163 ( = BLÂzQuEZ, Religiones).

$\left({ }^{47}\right)$ Estrabĩo, II, 3, 5; Julia, Monuments, p. 45-46; Berciu/Wolski, Contribution, p. 375; G. Cid Priego, El sepulcro de torre mediterráneo y sus relaciones con la tipologia monumental, «Ampurias», XI, 1949, p. 95-96, 112. 
o gentilicio, são elementos que, aliados aos dados sugeridos pela análise paleogràfica e pela problemática das cupae, permitem atribuir este monumento ao período de transição entre os séculos i e ii.

\section{2 - S. GIÃO. Foto 3}

Cipo de calcário lioz recuperado na ermida da Quinta de S. Gião, freguesia de Santa Maria, Torres Vedras, onde se encontrava aplicado como soleira de porta. Muito simples, não apresenta vestígios de ornamentação; tem as faces laterais alisadas e o dorso picado. $O$ estado de conservação é mau: o topo semicircular quase desapareceu; a base encontra-se truncada. A reutilização da pedra deteriorou gravemente a inscrição, provocando a perda da metade final das $1.2,3$ e 4 , cuia destruição corresponde, curiosamente, ao «desgaste» referido por Ricardo Belo. O campo epigráfico coincide com a totalidade da fachada do monumento, onde a epígrafe parece ter ocupado uma posição central.

Dimensões: 131x54,5x42. Campo epigráfico: $131 \times 54,5$.

C(aius). CAECILIVS/C (aii). F \{Mus). GA[L(ma tribu). GAE]/ /[T]VLIC[VS . AN (norum)]/ [X]VII[.]H(ic)[. S(itus) . E(st)]

Gaio Cecilio Getúlico, filho de Gaio, da tribo Galéria, de dezassete anos de idade, está aqui sepultado.

Altura das letras : 1. 1: 8,2;1. 2: 8,2;1. 3: 8,5; 1. 4: 8. Espaços : 1. 59,$5 ; 2: 1,5 ; 3: 1 ; 4: 1 ; 5: 35$.

\section{b) Bibliografia e variantes}

Resende, f. 46v; Strada, p. 174, 7; Muratori, 1647,9; CIL II 280; Pinho Leal, IX, 1880, p. 690; Belo, «Badaladas», 77, 1953; ILER 6339.

1.1: COECILIVS (STRADA); omitida por Pinho Leal.

1.2: omitida por PINHO LEAL.

1.2/3: COECILIVS, CAECILIVS (MURATORI).

1.3: AN omitido por RESENDE; IVII (PINHO LEAL).

1.4: omitida por Resende; XVIII (Pinho Leal). 


\section{c) Comentário}

As variantes referidas e a indicação de Muratori de que a inscrição se encontrava «in oppido Mont forte') levaram Hübner a considerar a hipótese de se tratar de inscrições diferentes. J. Vives indica-a como sendo proveniente de Lisboa, transcrevendo-a de Hübner com errada pontuação. Apesar dos estragos sofridos, o monumento sugere ainda a boa qualidade inicial. A paginação, embora transgredindo a regra de não cortar os nomes, talvez devido ao espaço disponível, pode considerar-se boa. O texto foi disposto segundo um eixo de simetria e, tanto quanto $o$ estado actual da inscrição permite verificar, ocupava todo o espaço central do campo epigráfico. $\mathrm{O}$ impecável alinhamento dos caracteres garante a utilização de linhas auxiliares. A pontuação sobrevivente é correcta e sóbria, formada por pequenos sinais circulares colocados a meia altura. A letra, bem proporcionada e de incisão tringular, é do tipo capital quadrada $\left({ }^{4 b}\right)$ : $G$ e $G$ bem recortados; o $A$ tem $o$ travessão horizontal $\mathrm{e}$ as hastes, tal como no $\mathrm{V}$, formam um triângulo isósceles; as barras do $\mathrm{E}$ e do $\mathrm{F}$ são idênticas e o desenho dos caracteres, clássico. $\mathrm{O}$ remate das letras foi cuidadosamente trabalhado. Há ainda que destacar a significativa ausência de nexos.

O que subsiste da inscrição não levanta quaisquer problemas de leitura e concorda com a transcrição de Hübner, confirmando a veracidade do texto, ainda que incompleto, transmitido por Resende.

A denominação do cidadão romano Gaio Cecilio Getulico corresponde ao que a LCM Iulia Municipalis prescrevia. Caius é um prenome vulgar, registado directa ou indirectamente em numerosas inscrições da região de Lisboa, nomeadamente numa outra epígrafe da Quinta de S. Gião (CIL II 296). O gentilicio Caecilius é um dos mais frequentes da epigrafia hispano-romana ( ${ }^{49}$ ),

(48) P. Batlle Huguet, Epigrafia Latina, Barcelona, 1946, p. 8; CAGNAT, p. 500, pi. VI, 2.

(49) ILER, p. 671-672; KNAPP, p. 217. 
representando $24 \%$ dos nomina assinalados na ilha de Maiorca $\left({ }^{60}\right)$. Segundo Tovar, tal abundância de testemunhos poderá retlectir relações de clientela com os Caecilii ligados à conquista e à administração da Península ( ${ }^{51}$ ), como o cônsul Q. Caecilius Mettelus Pius, cujo gentilicio se encontra em dois topónimos do itinerário Mérida/Astorga, por Salamanca (ILER 1778, III): Castra perto da moderna Cáceres, e Vicus Caecilius, na Serra de Gredos. Por outro lado, se o cognome usado por Caecilia Marina, presente numa inscrição de Faro (CIL II 5142), denuncia uma origem itálica (52), então poderemos relacionar com a imigração transalpina alguns dos testemunhos registados; outros, como a emeritense Quinta Caecilia Mauriola(ILER 5018) ou ainda como L. Caecilius Optatus, centurião da Legio VII Gemina e posteriormente magistrado municipal em Barcelona, terão origem africana ( $\left.{ }^{63}\right)$. No termo de Torres Vedras, os Caecilii estão representados em dois outros locais, além de S. Gião: Praia de Santa Cruz (51) e Carvoeira (CIL II 261). Em Lisboa, o gentilicio foi assinalado onze vezes ${ }^{55}$ ). Uma das inscrições foi dedicada pela cidade ao questor da Bética L. Caecilius Celer Rectus (CIL II 190); outra refere o edil P. Caecilius Gallus (CIL II 192). O cognome Gaetulicus, muito raro na Hispânia, parece relacionado com indivíduos de elevada posição social. Kajanto considera-o derivado do nome de um povo nómada berbere do Norte de África, os $\quad\left({ }^{56}\right)$, o que no presente caso poderá reflectir uma situação idèntica àquela que levou o cônsul sufecto do ano 81, possivelmente fdho do governador da Lusitânia L. Calventius Vetus Carminius a denominar-se L. Carminius Lusitanicus (PIR 434). Os Getulos eram excelentes cavaleiros que nomadizavam nas estepes dos Altos-Planaltos, a sul do Tell. Foram duros aliados de Jugurta na guerra contra os

( $\left.{ }^{\tilde{0} 0}\right)$ KNAPP, p. 199.

(5i) Tovar, Actes, p. 278.

(ö2) Schulze, Zur Geschichte lateinischer Eigennamen, Berlim, $1966^{2}$, p. 188-189.

(ö3) PATrick Le Roux, Recherches sur les centurions de la Legio VII Gemina, «Mélanges de la Casa de Velâzquez», VIII, 1972, p. 133-134.

(54) Alves Pereira, p. 264.

(55) A. Vieira da Silva, IEpigrafia de Olisipo, Lisboa, 1944, p. 277.

(56) Kajanto, Cognomina, p. 50. 
Romanos, a quem não poucas vezes colocaram em situação difícil. Como sucedia com outros povos da região, o seu policiamento era extremamente penoso e problemático; constituirán! sempre um grave factor de insegurança $\left({ }^{\tilde{o} 7}\right)$, obrigando a numerosas intervenções militares e, inclusive, a uma tentativa de estabelecimento do limes mais a sul, apoiado no oued Djedi( $\left.{ }^{58}\right)$. Uma parte dos Getulos serviu como auxilia no exército romano. Kajanto enumera vinte e nove exemplos deste cognome em África e vinte e cinco em Roma $\left({ }^{59}\right)$. Na Hispânia ocorre apenas quatro vezes: na inscrição de S. Gião, em Tortosa (CIL II 4066), em Campillo de Arena (Jaen, CIL II 2093) e em Ibiza (Baleares) na seguinte epígrafe: C. Iulio C. f. Gall Tironi Gaetulico j quaest. urb / tr. pl. praetori j amico optimo / L. Sempronius L. f. Quir. / Senecio (CIL Il 3661). Uma inscrição norte-africana refere um legado da Hispania Citerior denominado Iulius Gaetulicus (CIL Vili 8421). Há ainda um L. Numisius Gaetulus, em Córdova (CIL II 2298), um Porcius Gaetulus, em Málaga (CIL II 1976), e uma Iulia Gaetula, em Godella (Valência, CIL II 3780).

A hipótese do cognome Gaetulicus denunciar uma origem africana é reforçada pela análise da antroponimia dos cidadãos de Volubilis, cidade da Mauritania Tingitana onde o gentilicio Caecilius representa uma percentagem muito importante do total conhecido $\left({ }^{60}\right)$ e onde foram assinalados outros nomes que confirmam a existência de estreitas relações entre esta região africana e o Ocidente peninsulari61). Não devemos esquecer, inclusive, que a ocupação definitiva da Mauritania foi apoiada logisticamente a partir da Bélica e do Sul da Lusitânia e que as duas margens do golfo de Cádis constituem um todo geográfico permeável, bem

(s7) G. Charles-Picard, La Civilisation de VAfrique Romaine, Paris, 1959, p. 4-5; P. Romanelli, Storia delle province romane delVAfrica, Roma, 1959 , p. $133,177,183-187$.

(58) E. F. Gautier, Le Passé de VAfrique du Nord, Paris, 1952, p. $210-214$.

(59) KaJanto, Cognomina, p. 260.

$\left({ }^{60}\right)$ J. Gascou, La sucession des bornia vacantia et les tribus romaines de Volubilis, «Antiquités Africaines», 12, 1978, p. 115-121.

(61) Gascou, p. 118 (G. Gellius Seneca), p. 120 (Cornelia Amma)। Untermann, p. 159-160, mapa 68, p. 53, mapa 7; Fontes, p. 18-20. 
conhecido dos marinheiros locais de todas as épocas ( $\left.{ }^{62}\right)$, onde os grandes portos héticos dominaram os circuitos das exportações lusitanas e mauritanas para a Itália $\left({ }^{63}\right)$.

$\mathrm{Na}$ época imperial, a indicação da tribo exprime, com o sistema dos tria nomina, completando-o, a condição de direito do individuo, integrado numa sociedade rigorosamente hierarquizada ${ }^{(64)}$. É, com o gentilicio, um símbolo da cidadania romana completa( 6õ), tornado obsoleto depois da Constitutio Antonianma. Muito rara após meados do século ni, desaparece no período que medeia entre Aureliano e Diocleciano, registando-se um último exemplo numa inscrição de $333 / 337$ referindo uma personagem equestre de Hispellum ( $\left.{ }^{66}\right)$. Entre as várias tribos registadas na Península Ibérica, a tribo Galéria é a mais frequente ( ${ }^{67}$ ), nela tendo sido enquadrados os cidadãos do município olisiponense $\left({ }^{68}\right)$.

A fórmula que encerra a inscrição é das mais vulgares, aparecendo frequentemente isolada.

d) Dotação

A paleografia, o uso do nominativo, o sistema onomástico adoptado, a indicação da idade e a ausência de consagração aos deuses Manes permitem atribuir esta inscrição à segunda metade do século i.

(62) Raul Brandã O, Os Pescadores, Lisboa, 1972, p. 176-177.

(63) EST RA Bã O, II, 3, 4; III, 1, 8; H. CAMPS-FA B RER, $U$ olivier et $V$ huile dans VAfrique Romaine, Argel, 1953, p. 75-77.

(64) M. Grant, O Mundo de Roma, Lisboa, 1967, p. 119-124; Petit, p. $227-281$.

(65) G. Alföldy, Notes sur la relation entre le droit de cité et la nomenclature dans VEmpire romain, «Latomus», XXV, 1, 1966, p. 37-39, 55-57 (=ALFôLDY, Notes).

${ }^{(66)}$ G. ForNI, Il ruolo della menzione della tribu neWonomastica romana, «Actes du Colloque International sur l'Onomastique Latine», Paris, 1977, p. 99.

(67) ILER, p. 698; CIL II, p. LXV, p. 1134-1135.

(68) Vieira da Silva, p. 44; CAgNat, p. 78.

Conimbriga, 21 (1982), 5-99 
3 - S. GIÄO. Foto 4

a) Descrição

Cipo funerário de calcário lioz proveniente da ermida da Quinta de S. Gião, freguesia de Santa Maria, Torres Vedras. Sucessivas reutilizações tiveram consequências desastrosas para o monumento, provocando a quase total destruição do topo, de forma abaulada, e a perda de uma parte da inscrição, bastante escalavrada na parcela subsistente. $O$ campo epigráfico ocupava, aparentemente, toda a face do cipo, cujo dorso se encontra picado. Não há sinais de quaisquer molduras ou elementos decorativos.

Dimensões: 43x46x31. Campo epigráfico: ?x46.

L(ucio) . ANICIO OPTATO / ATTIVS MONTANVS / [D(e) . $\mathrm{S}($ uo ) . $\mathrm{F}$ (aciendum) . C(uravit)] / [H(íc) . S(iius) . E(st)]

Átio Montano mandou fazer à sua custa (este monumento) a Lúcio Anicio Optato (que) está aqui sepultado.

Altura das letras: 1.1: $6,4 \quad(0=5,5) ; 1.2: 6,4 \quad(0=5,5)$. Espaços: 1: 21,5( ?); 2: 1,2; 3: 1,2( ?).

b) Bibliografia e cariantes

Resende， f. 46v; Strada， p. 174，8; Gruter，880，8; SAlgado, p. 307; LeVy, 254, 593; CIL II 269; Belo, «Badaladas», 146, 1956; ILER 3623.

1. 1: Belo assinala a sigla L; MECiO (Strada, Gruter, SALGADO, LEVY).

1. 2: ANIVS (Belo); Belo assinala o nexo NT.

c) Comentário

Hübner, que não viu a inscrição, apoiou-se no texto transmitido por André de Resende, no qual a fórmula H. S. E. ocupa uma posição invulgar, repetindo-se apenas uma vez na região

Conimbriga, 21 (1982), 5-99 
olisiponense $\left(^{60}\right)$. Resende não indica a linha final da epígrafe que, na mesma folha do manuscrito e também proveniente de S. Gião, antecede a presente inscrição, linha que, na verdade, inclui a fórmula em causa (n. $\left.{ }^{\circ} 2\right)$. Terá sido transposta para o epitáfio de Optato? Na 1.2, a leitura Anius, proposta por Ricardo Belo, não é autorizada pela análise da epígrafe : não só a inclinação do $\mathrm{N}$ seria diferente da que se verifica nos restantes casos, como o travessão do primeiro $\mathrm{T}$ é perfeitamente visível. Confirma-se, assim, a leitura ATI IVS. Na bibliografia, Hübner indica, poi lapso, Levy 255, 596. Este, por sua vez e seguindo Fr. Vicente Salgado, atribuiu o monumento a Silves; J. Vives, observando a lição de Hübner, situa-o, porém, em Lisboa.

Apesar de algumas anomalias, a paginação obedeceu a um esquema exigente, reservando as duas primeiras linhas para indicação dos nomes do defunto $\mathrm{e}$ do ofertante $\mathrm{e}$ as duas últimas para o formulário. $\mathrm{O}$ recurso a linhas auxiliares permitiu obter um alinhamento rigoroso dos caracteres, denunciando um ordinator muito hábil e simultaneamente pouco formalista. $\mathrm{O}$ aspecto variegado das letras resulta, precisamente, desta última característica e não de rusticidade ou incapacidade do artista, o qual procurou conscientemente utilizar as letras como elementos decorativos $\left({ }^{70}\right)$. Pontuação aparentemente impecável, com sinais circulares. Os caracteres, bem gravados, de incisão triangular, são do tipo monumental, verticalmente alongados, acusando, todavia, influência da escrita actuária ${ }^{71}$ ), bem patente no $\mathrm{S}$ e no característico $\mathrm{N}$, o qual ocorre com frequência em inscrições monumentais da segunda metade do século II (72). $\mathrm{C}$ e $\mathrm{O}$ de excelente recorte, o último ligeiramente achatado: a pança do $\mathrm{P}$ é aberta; o travessão dos L e T, muito curto, é decididamente horizontal. O nexo NT é um dos mais vulgares da epigrafia latina. Pequenos ápices marcam a extremidade das letras.

Optato usava os tria nomina o que, por si só, não é suficiente para o classificar como cidadão romano, considerando a

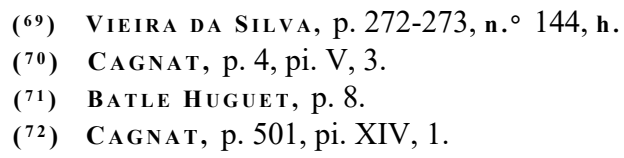


inscrição anterior ao século ui. Em princípio, depois de Vespasiano, não houve na Hispânia senão duas categorias de cidadãos: eives latini e eives romani ( $\left.{ }^{73}\right)$. Assim, a ausência total de referências familiares na inscrição leva-nos a atribuir-lhe a condição de liberto e a integrá-lo entre os cidadãos de direito latino ( $\left.{ }^{74}\right)$. Anicius é um gentilicio extremamente raro( $\left.{ }^{75}\right)$, aliás nem sempre referenciado entre os nomina (CIL II 2458); a inscrição de S. Gião faculta o único exemplo registado na Lusitânia. $\mathrm{O}$ cognome Optatus é romano e relativamente frequente na Hispânia não indo-europeia, especialmente na Bética $\left({ }^{76}\right)$. Na Lusitânia, província onde uma parte considerável dos testemunhos se situa entre as elites locais $\left({ }^{77}\right)$, foi assinalado nos seguintes pontos, além de S. Gião: Lisboa (CIL II 182, 206), Ferreira do Zêzere (CIL II 336), Faro (CIL II 5141), Mertola (CIL II 15), Mérida (CIL II 486, 564), Serra de Monsanto (ILER 683) e Zalamea de la Serena, onde se registou um Optatus da tribo Galéria pertencente à gens Attia e membro da ordo decurionum (ILER 6845). Kajanto engloba este cognome no grupo relacionado com as circunstâncias de nascimento, atribuindo-lhe um significado próximo de «agradável» $\left({ }^{78}\right)$; dos oitocentos e trinta e um exemplos conhecidos na Romania, cento e quarenta pertencem a escravos, o que representa uma percentagem importante $\left({ }^{79}\right)$. Este facto pode explicar, em parte, a distribuição do cognome na Península, nomeadamente a sua concentração na rica região da bacia do Guadalquivir e nalguns dos grandes portos hispânicos, como Cádis (CIL II 1753, 1778, 1779, 1807, 1858, 1874), o que destaca imediatamente uma activa intervenção em actividades comerciais

(73) Alföldy, Notes, p. 49-50; Alarcão, Portugal, p. 55.

(74) O. Hirschfeld, Kleine Schriften, Berlim, 1913, p. 298; Alföldy, Notes, p. 55-57.

(75) Albertos, Antropónimos, XXXII, 2, 1964, p. 220; XL, 2, 1972, p. 13.

(76) UntermanN, p. 140-141, mapa 58; ILER, p. 727.

(77) O conjunto inclui um Augustal, um duúnviro, um magistrado municipal indeterminado e a mulher de um liberto imperial tabularius da Lusitânia.

(78) KaJanTo, Cognomina, p. 73-75.

j79) KaJanto, Cognomina, p. 77, 296.

Conimbriga, 21 (1982), 5-99 
e marítimas, em grande parte controladas por libertos $\left(^{80}\right)$, as quais justificarão o Optatius do testemunho isolado registado em Grava (Pontevedra, ILER 587), região relacionada com a rota atlântica dos minérios. Conhecem-se dois Optati Augustais: um C. Arrias Optatus, em Lisboa (CIL II 182), e um 0. Valerius Optatus, em Alcaudete (Jaén, CIL II 1721). A família dos Aelii Optati, grandes exportadores de azeite estabelecidos na Bética $\left({ }^{81}\right)$, merece uma referencia especial: as suas marcas anforárias foram encontradas em varios locáis do mundo romano ${ }^{82}$, incluindo Roma( $\left.{ }^{83}\right)$, e é provável que o L. Aelius Optatus de uma muito deteriorada inscrição de Faro (CIL II 5141) lhe pertença, atendendo ao local do achado, escala importante da rota que ligava o Tejo aos grandes centros portuários da Bética e presumível sede de uma procuradoria das minas do $\mathrm{Su}$ da Lusitânia ( ${ }^{84}$ ) ; o teor honorífico do monumento, típico do grupo social que controlou a vida económica e política regional e provincial, reforça consideravelmente a relação estabelecida. Quanto à gens Attia tem raros representantes na Hispânia $\left({ }^{85}\right)$. Ausente das regiões limítrofes de Torres Vedras, este gentilicio, dos mais antigos do Lácio, tem no Conventus Pacensis uma distribuição significativa: Faro (CIL II 5141), Mirobriga (Santiago do Cacém, CIL II 21), Tróia e arredores de Eivas (86); em Faro, a inscrição funerária de $L$ Attius Nisus refere um raríssimo misolio sub ascia, facto que podemos considerar como indicador, quase certo atendendo ao gentilicio, de relações com a Narbonense ( ${ }^{87}$ ); a epígrafe de Miro-

$\left(8^{\circ}\right) \mathrm{p}_{\text {ETIT }}$ p. $285-287$.

(81) E. Thоuvenot, Una familia de negociantes en aceite estabelecidos en la Bélica en el siglo II: los Aelii Optati, «Archivo Español de Arqueologia», XXV, 86, 1952, p. 225-231; M. Ромsich. Implantation rurale antique sur le Bas-Guadalquivir, Madrid, 1974, p. 150-152, 157.

(82) M. H. Callender, Roman Amphorae, Londres, 1965, p. 199, n. 1266.

(83) E. Rodriguez Almeida, Novedades de epigrafia anforaria del Monte Tesiaccio, «Recherches sur les Amphores Romaines», Roma, 1972, p. 130-137.

$\left.{ }^{84}\right)$ M. Euzennat, Lingots espagnols retrouvés en mer «Etudes Classiques», 3, 1968-1970, p. 95-98.

(85) KNAPP, p. 121.

(86) ENCARNAÇÃo, Inscriptions, p. 54.

${ }^{87}$ KNAPP, p. 196, 215, 218. 
briga foi consagrada a Esculápio pelo médico pacense C. Attius Ianuarius. O cognome itálico Montanus é mais vulgar. Kajanto relaciona-o com factores de ordem geográfica, traduzindo-o por «montanhês» $\mathrm{V}^{88}$ ). Foi assinalado praticamente em todo o Império $\left.{ }^{89}\right)$, contando fraca representação na Hispânia $\left({ }^{90}\right)$ onde eventualmente surge relacionado com a elite municipal provincial $\left({ }^{9]}\right)$. Em Portugal foi ainda referenciado em Lisboa (CIL II 221, 4999), Beja (CIL II 68), Aljubarrota (CIL II, 355) e numa ara consagrada a Júpiter, em Monsanto (CIL II 459). Uma inscrição de Mérida poderá referir um Q. Attius Montanus (CIL II 535); um dos seviri Augustales de Tarragona denominava-se M. Raecius Montanus (CIL II 4304); o cognome foi também registado nas Baleares: melhor situado no cursus do culto imperial, Maecius Maecianus Montanus foi flàmine provincial da Hispania Citerior, como informa a epígrafe de uma base de estátua encontrada em Mahón (CIL II 3711); outra referência provém de Palma de Maiorca (CIL II 5222). Da Mauritania conhecemos um governador da Tingitana, contemporâneo de Antonino, denominado Q. Aeronius Montanus (CIL Vili 21825). As observações anteriormente feitas acerca do estatuto social de Optato são igualmente válidas para Montano, mas, neste caso, fortemente contrariadas pelo cognome: dos trezentos e vinte e três exemplos conhecidos, apenas vinte se referem a libertos e escravos $\left({ }^{92}\right)$; a ausência do prenome, vulgar a partir do século $\mathrm{m}\left({ }^{93}\right)$, não impede a sua classificação como cidadão ( $\left.{ }^{91}\right)$. Os cognomes Optatus e Montanus aparecem associados numa inscrição, relacionada com os Aelii Optali já citados, proveniente de Peñaflor (Lora del Rio, CIL II 2329 /2330); um outro ramo dos Aelii peninsulares, talvez de

(88) KaJanto, Cognomina, p. 80-81.

$\left.{ }^{89}\right)$ D. Protase, O familie de origine italica la Apulum, «Apulum», IX, 1971, p. 355-356.

(90) ILER, p. 722.

(91) M. M. Alves Dias, M. Fabius Paulinus and L. Numisius Montanus. A Contribution to the Knowledge of the Hispanic Municipal Elites under Hadrian, «Madrider Mitteilungen», 19, 1978, p. 263-271.

(92) Kajanto, Cognomina, p. 309.

(93) Huguet, p. 73.

(94) AlFöldy, Notes, p. 38; Fouilles, p. 93-95, n. 71 (séc. ii). 
origem bética (90̃), encontra-se representado em S. Miguel de Odrinhas por uma notável inscrição (CIL II 267). O gentilicio uAttius e o cognome Montanus ocorrem igualmente numa inscrição pintada sobre uma ânfora D. 20 do Castro Pretorio, em Roma (CIL XV 3644), referindo um Montanus, aparentemente proprietário de um fundus situado na região hética de Arcai96), e o negotiator e possível armador P. Attius Severus. Desta forma, e apesar da qualidade e exiguidade dos testemunhos lusitanos, não nos parece inviável considerar L. Anicio Optato e Ätio Montano relacionados com actividades inerentes às exportações peninsulares para Roma, as quais, embora centradas na Bética, foram suficientemente importantes em Olisipo para que delas ainda hoje subsistam traços na epigrafia (CIL II 293, 5019).

\section{d) Dataçào}

A análise interna e externa desta epígrafe truncada não é das mais fáceis. Permite, contudo, atendendo à não consagração aos deuses Manes, ao uso do dativo, à sobriedade do texto e aos factores paleográficos, datá-la da segunda metade do século n.

\section{4 -TORRES VEDRAS. Foto 5}

\section{a) Descrição}

Grande pedestal funerário de calcário lioz, proveniente da capela de S. João Baptista, freguesia de S. Pedro, Torres Vedras. No século XVI, como refere Strada, encontrava-se no interior, perto do altar, local de onde foi posteriormente deslocado, tendo sido redescoberto em 1847 reutilizado num cunhal exterior (97). Sem decoração, cuidadosamente alisado na face e nos flancos, este

(90̃) UNTERMANN, p. 159-161, mapa 68.

(98) Ponsich, p. 155, 160, 166, fig. 65.

(97) Pinho Leal, IX, 1880, p. 664; Vieira, p. 5. 
monumento pouco deteriorado situa-se entre os melhores que se conservam no Museu. No topo ostenta três entalhos geometricamente dispostos, dois junto à aresta posterior e um terceiro, maior, aberto numa posição central. $\mathrm{O}$ dorso, desbastado e picado, é característico deste tipo de monumento. O campo epigráfico ocupa todo $\mathrm{o}$ rosto do pedestal sem que todavia a inscrição o preencha por completo.

Dimensões: $143 \times 73 \times 41$. Campo epigráfico: $143 \times 73$.

M (arco) . IVLIO . M(arci) . F (ilio) . GA Ueria tribu) / CRESCENTI / L(udas). VALERIVS . ARCO . SOCER / EX . T(estamento) . F faciendum) . C (aravit) . S (it) . T (ibi) (hedera) T (erra). L (evis) [hedera)

A Marco Júlio Crescente, filho de Marco, da tribo Galéria, o sogro, Lúcio Valério Arcão, por disposição testamentària, mandou fazer (este monumento). Que a terra te seja leve!

Altura das letras: 1. 1: 7,5; 1. 2: $6,5(\mathrm{M}=8)$; 1 . $3: 5,5(0=5,8$; $\hat{E R}=5,8) ; 1.4: 5,3$. Espaços: 1: 10; 2: 2,5; 3: 1,8; 4: 2; 5: 102.

\section{b) Bibliografia, e variantes}

Sth A D A, p. 173, 8; Gruter, 567, 3; LeVy, 249, 583; Torres, p. 19; CIL II 321; Pinho Leal, IX, 1880, p. 664; Vieira, p. 5; Belo, «Badaladas», 57, 1952; GEPB, XXXII, 1960, p. 277; ILER 4749 .

1.1: TAlliO (Strada, Gruter, Levy, CIL II, ILER), CA (Pinho leal), CAI (Vieira), CA. (GePR).

1.3: Strada, Cruter, Levy, CIL II, Vieira e ILER omitem a sigla L; ACRO (Strada, Gruter, Levy, CIL li, ILER), ARCOS (Pinho Leal), Socr (Strada, Gruter, Levy, torres CIL II, Pinho Leal, Vieira, Belo, CPER, ILER).

1.4: pontuação incompleta em Strada, Gruter, Levy, Torres, CIL IT, Vieira, ILER; Pinho Leal omite o F. 


\section{c) Comentário}

J. Vives indica Lisboa como local de proveniência desta epígrafe incontestavelmente tómense, registada e recuperada numa zona da cidade onde os vestígios antigos não faltam ( $\left.{ }^{98}\right)$. A paginação foi cuidadosamente elaborada e dela resultou uma distribuição do texto agradável e equilibrada, ocupando apenas o terço superior do campo epigráfico. O lapidarius utilizou linhas auxiliares, ainda muito fracamente visíveis nalguns pontos. Todavia, toda a inscrição está ligeiramente inclinada sobre a esquerda, notando-se ainda uma pequena deslocação das 1. 2 e 4 no sentido da direita. O ordinator respeitou habilmente a regra da integridade das palavras ao variar as dimensões das letras, usando as duas primeiras linhas para identificação privilegiada do defunto, reservando a segunda para o cognome, que assim se destaca vigorosamente no conjunto do texto; a 1.3 contém a identificação do executor testamentàrio, ficando o formulário confinado na última linha. Pontuação rigorosamente colocada e trabalhada com intenção decorativa, ostentando três tipos de sinais: «vírgulas*, triângulos e heras cordiformes. A gravação, em bisel, é muito regular e perfeitamente nítida. Escrita do tipo capital quadrada, bem proporcionada e, salvo uma ou outia irregularidade, de bom desenho, com os ápices ligeiramente traçados; $\mathrm{M}, \mathrm{N}, \mathrm{O}$ e $\mathrm{G}$ de recorte clássico; o $\mathrm{G}$ é próprio da escrita actuária e encontra-se documentado em numerosas inscrições dos séculos i e II( $\left.{ }^{99}\right)$; o $\mathrm{R}$ apresenta a haste oblíqua recta e com o ponto de partida da pança muito afastado da haste vertical, forma que ocorre, por exemplo, em epígrafes luso-romanas do início da época imperial encontradas em Idanha-a-Velha $\left(1^{\circ}\right)$ e Silveirona, perto de Estre-

(98) Leonel Trindade/Yeiga Ferreira, Objectos inéditos lusitano-romanos de Torres Vedras, «Boletim Cultural da Junta Distrital de Lisboa», 61-62, 1960, p. 269-273 (= Leonel Trindade/Veiga Ferreira, Objectos).

(") Batlle Huguet, p. 12-13; Cagnat, p. 500, pi. Y, 1, 5; Fouilles, p. 49-51, n. ${ }^{\circ}$ 24, pi. VII; em Lisboa, por exemplo, ocorre na inscrição do proscenium do teatro romano: Vieira da Silva, p. 172-175, n. ${ }^{\circ} 70$.

$\left(1^{\circ}\right)$ D. Fernando de Almeida, Egitânia. Arqueologia e História, Lisboa, 1956, p. 140-141, n. ${ }^{\circ}$ 1, fig. 105 (= ALmeID A, Egitânia). 
$\operatorname{moz}\left({ }^{101}\right)$; os L, A e $\mathrm{T}$ têm os travessões geralmente rectos, idênticos em comprimento no $\mathrm{E}$, acusando certa influência cursiva, nomeadamente no 1.2. O nexo ER não é dos mais frequentes: colocação e isolamento sugerem uma datação recuada (102). No final da 1 . 1 o L, embora muito prejudicado, é de fácil identificação. $\mathrm{Na} 1.3$ o L da abreviatura do prenome Lucius subsiste e a sua leitura não exige esforço especial.

A qualidade da inscrição e as dimensões do suporte obrigam imediatamente a relacionar este monumento com um ambiente social e económico elevado e plenamente romanizado. A referência à tribo Galéria, os tria nomina e as implicações jurídicas da fórmula final afirmam a cidadania de M. Julius Crescens e de L. Valerius Areo. A identificação do último concorda com a identificação simplificada, omitindo filiação e tribo, de indivíduos confirmadamente cidadãos responsáveis pela execução de monumentos funerários. O gentilicio Julius é, como já vimos, um dos que reúne maior representação na Península. $\mathrm{O}$ muito vulgar cognome romano Crescens, para o qual Iíajanto refere a longínqua possibilidade de uma origem geográfica, a partir do rio Crescens, afluente do Reno $\left({ }^{103}\right)$, é relativamente frequente na Península ( ${ }^{104}$ ), sobietudo nas grandes cidades do Levante, assim como na Bética e na Lusitânia. Na província lusitana, que concorre com cerca de metade dos exemplos registados, é desconhecido no concentus pacense e tem fraca representação no escalabitano, onde, além do testemunho torriense, se conhecem outros, provenientes de S. Sebastião do Freixo (CU) II 5235) e de Idanha-a-Velha (CIL II 439), se é que o território dos Igaeditani lhe pertencia; atinge, porém, notável concentração no concentus emeritense, tendo sido assinalado em Merida (ILER 4606), Villagarcía (Badajoz, CIL II 1035), Reina (Badajoz, ILER 2535), Cáceres (CIL II 697, 705), Torrequemada (Cáceres, ILER 5077), Arroyomolinos (Cáceres, ILER 6167), Trujillo (ILER 2272, 6754), Cória (CIL II 765)

(101) José D'EnCarnaÇÂAo, Epigrafia do Nordeste alentejano, «Conimbriga», XVI, 1977, p. 67-68, n. ${ }^{\circ}$ 5, fot. 8 (= ENCARNAÇ Ão, Nordeste).

(ío2) BatLe Huguet, p. 17.

(103) IVajanto, Cognomina, p. 234.

(104) ILER, p. 684. 
e Oropesa (CIL II 994). Uma das epígrafes de Cáceres nomeia um L. Iulius Crescens (CIL II 705). Na Bética, o cognome foi assinalado entre os grandes negotiatores provinciais, destacando-se, pelo volume da sua produção anforária, o astigitano L. Fabius Crescens (105). O gentilicio Valerius, extraordinariamente bem documentado na Hispânia (106), não é raro na região de Lisboa (CIL II 254, 259, 321, 322, 323); em Conimbriga registaram-se dez exemplos $\left({ }^{107}\right)$, relacionados, na maioria, com o meio indígena. No presente caso, o cognome de origem céltica Arco permite estabelecer idêntica relação $\left.{ }^{108}\right)$. Vulgar na área calaico-lusitana $\left({ }^{109}\right)$, é raro na região olisiponense, onde apenas se lhe conhece outro testemunho, assinalado em Mafra (CIL II 5223). Presente, como teónimo, em Siguenza (no), Arco constitue o radical de um dos epítetos da deusa Navia (ILER 891) e do topònimo Arcobriga (CIL II 765, 2419). 0 rio Arcão, afluente do Sado, poderá reflectir o mesmo étimo.

Nesta epígrafe deparamos, mais uma vez, com um fenómeno de aculturação típico do processo de romanização e traduzido na aclopção da antroponimia latina e simultânea sobrevivência de nomes indígenas, introduzidos no sistema legal dos tria nomina como cognomes, mas não propriamente integrados, permanecendo como indicativo seguro da origem étnica e social dos indivíduos, como defende Kajanto $(\mathrm{m})$. Dada a qualidade da romanização na região em torno de Olisipo, iniciada ainda no século $\mathrm{n}$ a.C., não nos parece por completo viável, contrariando Tovar (112), atribuir a persistência dos nomes indígenas no Ocidente peninsular, nomeadamente na referida zona, a um processo romanizador lento. Teremos que procurar outra explicação, ou uma explicação complementar, relacionada não tanto com os sucessos militares e políticos,

(105) Callender, p. 153-155, n. ${ }^{\circ} 851$.

(106) ILER, p. 760-762; KNAPP, p. 191, 218, 221.

(107) Fouilles, p. 225-226.

(108) Albertos, Antropónimos, XXXII, 2, 1964, p. 223-224.

(109) UntermanN, p. 58-59, mapa 10.

(110) Blázquez, Religiones, p. 103.

(m) I. Kajanto, The Significance of Non-Latin Cognomina, «Latomus», XXVII, 3, 1968, p. 517-534 (= Ka Jant o, Non-Latin Cognomina).

(na) Tova R, Actes, p. 268.

Conimbriga, 21 (1982), 5-99 
mas fundamentalmente com uma nova ordem cultural propiciada por uma flexível interpretatio de tudo o que podia ser assimilado ou tolerado, a qual permitiu que a Romania fosse bastante mais do que um simples quadro político e jurídico.

$\mathrm{O}$ formulário que encerra o epitáfio é normal. Por ele sabemos que Arco foi o executor testamentàrio do genro, incumbência vulgar mas que não raramente suscitava contendas familiares $\left({ }^{113}\right)$.

d) Datação

A ausência de consagração aos deuses Manes, a falta de indicação da idade, a lacónica referência a laços familiares são factores que, aliados à paleografìa, permitem atribuir este importante monumento à primeira metade do século $i$.

\section{5 - TORRES VEDRAS. Foto 6}

\section{a) Descrição}

Placa funerária, truncada, de calcário lioz, encontrada em 1948 no entulho de uma cisterna antiga situada a meia encosta do Monte do Castelo, freguesia de Santa Maria, Torres Vedras. Muito simples, sem ornamentação, a metade que dela resta encontra-se razoavelmente conservada e faculta um texto que, apesar de incompleto, permite uma leitura coerente. A placa era de forma rectangular e foi afeiçoada no reverso e cuidadosamente alisada na face principal, aparentemente ocupada na totalidade pelo campo epigráfico.

Dimensões: $50 \times 40 \times 26,5$. Campo epigráfico: $50 \times$ ?

[...] Q (uinti) . F (Mus) . GAL \{cria tribu)/[...] S . ANN (orum) . XIX / [...] . IVLIA /['... M]ATER F(aciendum) C(uravit)

(113) Alarcão, Portugal, p. 185-186. 
(...)s, filho de Quinto, da tribo Galéria, de dezanove anos de idade (...)• A mãe Júlia (...) mandou fazer (este monumento).

Altura das letras: 1. 1: 6,3; 1. 2: 6,3; 1. 3: 5,6; 1. 4: 5,6. Espaços: $1: 6 ; 2: 2,5 ; 3: 2,5 ; 4: 2,5 ; 5: 12,5$.

\section{b) Bibliografia e variantes}

BELO, «Badaladas», 56, 1952 (foto).

1. 1: CAL (BELO).

1. 4: BELO indica um ponto de separação antes da fórmula final.

\section{c) Comentário}

O que resta da epígrafe permite reconstituir a paginação, uma vez que possuímos aproximadamente metade do texto e que este, pela sua natureza, correspondia a regras seguramente estabelecidas e ampiamente documentadas. Observando um procedimento normal, o ordinator concentrou a inscrição, reservando as 1.1 e 2 para indicar a identidade e a idade do defunto, recebendo as 1.3 e 4 o nome da dedicante $\mathrm{e}$ as fórmulas finais habituais. Uma tentativa de restituição completa do texto, possível a partir do cálculo das dimensões originais da placa, resultaria forçosamente suspeita sem nada adiantar aos elementos concretos facultados pelo monumento. Assim, referiremos apenas o seguinte : o gentilicio contido na 1.1 ocuparia pouco espaço, não sendo de excluir a hipótese de ter sido gravado abreviado (114), como se verifica na inscrição torriense da igreja de Santa Maria do Castelo (n. ${ }^{\circ}$ 6); na 1.2 subsiste a última letra de um cognome extenso, decerto terminado em VS; a 1.3 incluiria, pelo menos, a fórmula H.S.E.; finalmente, a 1.4 compreendia um cognome de desenvolvimento médio, pequeno no caso de ser precedido pela filiação (CILII 261, 296). O alinhamento, nitidamente guiado, valorizou a inscrição alternando a extensão das linhas. A pontuação, correcta, tem os sinais em forma de acento agudo, o que

(114) Cagnat, p. 51-52.

Conimbriga, 21 (1982), 5-99 
não é muito vulgar (115); a omissão do ponto entre as duas siglas da fórmula FC é frequente. A gravação, pouco profunda, é de incisão triangular. As letras, bem documentadas em inscrições dos séculos i e $\mathrm{n}\left({ }^{116}\right)$, acusam ligeira inclinação sobre a direita; ostentam ápices e são do tipo capital quadrada, com franca influência actuária, eventualmente devida a uma ordinatio desenhada a pincel, presente no traçado ondulado dos travessões do F; o Q tem uma forma oval rematada por uma cauda pequena $\mathrm{e}$ graciosa; $\mathrm{R}$ do tipo aberto, com a haste oblíqua recta. No conjunto, é uma epígrafe não desprovida de elegância, embora um tanto ou quanto rígida, denunciando um tratamento algo despreocupado, de qualidade mediana.

A referência à tribo Galéria é perfeitamente normal, admitindo a integração da região de Torres Yedras nos confins do território de Olisipo, município indubitavelmente adstrito àquela tribo, a mais difundida na Península antes da época ílaviana $\left({ }^{117}\right)$. O pronome de base numeral Quintus, embora vulgar, tem distribuição pouco equilibrada: frequente em Lisboa, onde foram registados vinte e quatro exemplos (118), concentração que se reflecte no único testemunho eborense (CIL II 124), rareia ou falta por completo noutras grandes cidades lusitanas. Em Torres Vedras repete-se na inscrição de Santa Maria do Castelo (n. ${ }^{\circ}$ 6) e foi assinalado, nos arredores, em Matacães (n. ${ }^{\circ}$ ). Carvoeira (n. ${ }^{\circ} 12==$ $=C I L$ II 261) e Azueira (CIL II 302). Quanto ao gentilicio registado é, como já vimos, o mais vulgar da epigrafia hispano-romana, o que em parte se relaciona com a presença de Augusto na Península (119). A fórmula $\mathrm{F}$ (aciendum) $\mathrm{C}$ (uravit) é habitual; precedida da palavra MATER, que ocorre eventual mente como cognome ( $\left.{ }^{120}\right)$, repete-se, por exemplo, em S. Gião (CIL II 296) e, associada a D. M., em Santa Cruz (CIL II 114).

(115) Batlle Huguet, p. 26.

(116) Batlle Huguet, p. 114-115.

(117) Cagnat, p. 78; R. Étienne/G. Fabre, C. 1 irra?dus Ru;us de Conimbriga, «Conimbriga», XI, 1972, p. 200-203.

(118) Vieira da Silva, p. 276-283.

(119) Dĩ̃o GÁssio, 54, 25.

$\left(1^{\circ}\right)$ Kajant o, Cognomina, p. 80, 103.

Conimbriga, 21 (1982), 5-99 
Em Torres Vedras têm sido descobertos significativos vestígios da época romana, decerto relacionados com uma povoação que ocuparia, de forma não contínua, o Monte do Castelo, onde na vertente norte se situam as ruínas de duas cisternas talvez romanas (121), numa das quais foi encontrada a presente inscrição, e a zona antiga da cidade que se estende para oriente até ao Sizandro. Nas muralhas e na igreja de Santa Maria do Castelo, de cuja escadaria provém a árula recentemente recolhida no Museu (n.. ${ }^{\circ}$ ), é visível a reutilização de materiais antigos e temos conhecimento da descoberta de uma moeda do Baixo-Império e de fragmentos de vidro no interior da fortaleza.

\section{d) Dalação}

O tipo de escrita, a simplicidade do formulário subsistente, o gentilicio, a ausência de adjectivos, a indicação da idade, são factores que permitem atribuir esta inscrição ao final do século $\mathbf{T}$.

\section{6 - TORRES VEDRAS. Foto 7}

\section{à) Descrição}

Árula funerária de calcário lioz, retirada em 1979 do muro esquerdo da escadaria de acesso à igreja de Santa Maria do Castelo, freguesia de Santa Maria, Torres Vedras. O monumento, trabalhado nas quatro faces, encontra-se muito danificado: uma fractura antiga eliminou o capitel e prejudicou o campo epigráfico, estabelecido sem decoração sobre uma das faces principais do fuste. A base, terminada por uma espécie de plinto destinado a fixar a árula num soco, possui uma moldura, muito destruída, 
de perfil relativamente complicado algo semelhante à de uma base ática. $\mathrm{O}$ mau estado geral da pedra é ainda agravada por alterações de origem química.

Dimensões: 52,5 (base: 20,5; fuste: 32) x34,5x22. Campo epigráfico: ?x34,5.

$\mathrm{Q}$ (uinto) BOVIO ATIM/ETIONI VICTORI / (Quinti) B(am) MARCIANI / ANN(orum) LXX/5 Qiuintus) B(ovius) POTITVS / / PATRI OPTVMO

A Quinto Bóvio Atimecião Vítor, (filho) de Quinto Bóvio Marciano, de setenta anos de idade. Quinto Bóvio Potito (mandou fazer este monumento) a seu excelente pai.

Altura das letras: 1. 1: 4; 1. 2: 4 (ET: $E=3,2)$; 1. 3: 4; 1. 4: 4; 1. $5: 4 ; 1.6: 3$ (1=2,2). Espaços: $1: 1 ; 2: 1 ; 3: 0,5 ; 4: 0,5 ; 5: 0,5 ; 6: 2$.

b) Bibliografia e variantes

Inédita.

c) Comentário

$\mathrm{Na}$ zona de Lisboa, as árulas funerárias são relativamente raras: no Museu de S. Miguel de Odrinhas, por exemplo, há apenas duas (122). A que agora se descobriu em Torres Vedras constitui, assim, um testemunho valioso da implantação das formas plásticas romanas na região. $\mathrm{O}$ ordinator teve a preocupação de conseguir uma paginação elegante e correcta, utilizando um esquema perfeitamente clássico, distribuindo o texto segundo um eixo de simetria e fazendo alternar a extensão das linhas. Tendo em conta a qualidade da paginação, é de admitir que as deficiências verificadas na epígrafe se devam, sobretudo, ao lapidàrio. Na 1.1 a translineação cortou o cognome sem atender à divisão silábica. $\mathrm{Na} 1.3$

(i22) Mário Gardozo, Novas inscrições romanas do Museu Arqueológico de Odrinhas, Sintra, 1958, p. 11-12, n. ${ }^{\circ}$, p. 17, n. 8 (= Cardozo, Inscrições). 
e 5 o gentilicio, em parte devido ao espaço disponível, em parte devido a já se encontrar desenvolvido na 1.1, foi indicado em sigla. Não há vestígios de pontuação. A regularidade do conjunto denuncia a existência de linhas auxiliares, desaparecidas. A letra é do tipo monumental, com forte influência actuária; tem razoável gravação em bisel. Ligeiramente inclinada sobre a direita, acusa uma ou outra irregularidade no ductus e mostra traços de ápices. Destacaremos apenas o seguinte: o Q, circular, assenta na linha apenas a extremidade da cauda, o que provoca um efeito deselegante; o B, de panças desiguais, tem um desenho clássico (123) ; o O, elíptico, difere por completo do corpo do Q; travessões perfeitamente horizontais, a meia altura no $\mathrm{A}$, muito curtos no $\mathrm{T}$; $\mathrm{R}$ com a haste oblíqua recta, obtido a partir do $\mathrm{P}$, aberto; o $\mathrm{M}$ tem as hastes exteriores divergentes e o ângulo interno, como no $\mathrm{V}$, bem colocado ao centro, sobre a linha; o $\mathrm{S}$ é próprio da escrita actuária ( $\left.{ }^{124}\right)$. O nexo ET é normal (125).

A epígrafe apresenta alguns problemas de leitura. É possível que tenha existido uma primeira linha contendo a fórmula D.M. ou D.M.S., considerando o esquema geral do texto $\left({ }^{126}\right)$. Na 1.1 o gentilicio BOVIO lê-se com facilidade, o mesmo não sucedendo, porém, com as letras iniciais do cognome, ATIM. Na 1.2 o problema complica-se, mas a fotografia e a análise directa da pedra permitem afirmar a existência do nexo ET : teremos, assim, o dativo ATIMËTIONI. Segue-se a palavra VICTORI, na qual pouco resta das duas letras iniciais. Na 1. 3 a sigla do prenome está representada pela cauda do $\mathrm{Q}$ e por uma fractura que o sugere; o cognome, bastante maltratado, mostra a seguir ao $\mathrm{M}$ vestigios nítidos de um $\mathrm{A}$, assim como um $\mathrm{R}$, de que resta a pança e a extremidade da haste oblíqua, e um C, custosamente visível, seguido de IANI, o que dá o genitivo MARCIANI. $\mathrm{Na} 1.4$ subsistem traços do segundo $\mathrm{N}$ da abreviatura ANN. $\mathrm{Na} 1.3$ falta a sigla ou abreviatura de filius: lapso do lapidarius? O texto de uma sofisticada inscrição de Conimbriga (CIL II 391),

(123) HUGUET, p. 11.

(124) HUGUET, p. 15-16.

(125) Huguet, p. 20 ; CARDozo, Inscrições, p. 25-26, n. 14.

(126) Fouilles, p. 214. 
que fornece umparalelo elucidativo ao esquema da epígrafe torriense, repetido numa inscrição proveniente de Lourel (Sintra, CIL II 299), leva-nos a aceitar tal hipótese, tanto mais que se trata de um facto muito vulgar na epigrafia hispano-romana de menor qualidade $\left({ }^{127}\right)$. A solução proposta, sem ser a única possível, como veremos, parece-nos a mais plausível.

O gentilicio Bovius, considerado por Schulze de origem etrusca (128), poderá ter como radical o indo-europeu ${ }^{*} g w o u-$ boi, vaca $\left({ }^{129}\right)$. Os poucos testemunhos peninsulares conhecidos situam-se quase todos na Lusitânia Ocidental: patente em inscrições de Oeiras (CIL II 5011) e de Coimbra, esta de grande qualidade (CIL II 378), foi assinalado como nome único em monumentos de Louriceira, perto de Tones Vedras (n. $\left.{ }^{\circ} 11\right)$, Sacóias (Bragança, ILER 2609), Meixedo (Bragança, ILER 5044), Albuquerque (ILER 2451) e Idanha-a-Velha $\left({ }^{130}\right)$. A sua leitura como cognome, numa cupa da Praia de Santa Cruz, é francamente duvidosa $\left({ }^{131}\right)$. Atimetio é um cognome de indiscutível origem grega (132) que, segundo julgamos, aqui surge pela primeira vez na Hispânia. Um antropònimo parecido, utilizado como nome de escravo e como cognome, Atimetus ( $\left.{ }^{133}\right)$, foi registado em Tarragona (CIL II 4089, 4118), Valência (CIL II 4813), Cádis (ILER 3001), Itálica (CIL II 1142), Mérida (CIL II 532), Conímbriga (134) e numa marca de lucerna, de origem desconhecida (CIL II 49699). Atimetio está documentado em Roma por uma inscrição funerária (CIL VI 34559) e por marcas anforárias do começo do século ru (CIL XV 4098, 4100, 4108, 4112). Victor é um cognome latino, não anterior ao século $\mathrm{m}$ a.C. e que terá sido inicialmente um agnomen ex virtute, por firn transformado em cognome ex hereditate, talvez por influência dos epítetos atribuídos a

(127) HUGUET, p. 32.

(128) SCHULZE, p. 234.

(129) Albertos, Antropónimos, XXXII, 2, 1964, p. 213.

(130) Almeida, Egitânia, p. 167, n. ${ }^{\circ} 40$, fig. 123.

(131) Alves Pereira, p. 264.

(132) Thesaurus Linguae Latinae, II, Lipsia, 1909, p. 1039.

(133) Thesaurus, II, 1909, p. 1039.

(134) Fouilles, p. 69-70. n. ${ }^{\circ} 40$. 
certas divindades $\left({ }^{135}\right)$. No caso presente trata-se, sem dúvida, de um segundo cognome, uso pouco frequente na epigrafia da região de Lisboa (CIL II 256, 354), explicável pelo processo de multiplicação dos cognomina verificado a partir do século ii $\left.{ }^{136}\right)$. Dos mil quinhentos e sessenta e oito exemplos deste cognome referidos por Kajanto, seis pertencem à classe senatorial, cinquenta e um são escravos e libertos e setecentos e setenta e um foram assinalados no Norte de África ${ }^{137}$ ). Largamente representado na Península Ibérica $\left.{ }^{138}\right)$, em especial no Sul e no Levante, região onde, naturalmente, se destaca Tarragona (CIL II 4187, 4303, 4416, 6109), tem limitada ocorrência na Lusitânia: já referenciado em Mérida (ILER 4142, 4390), Cáceres (CPIL 154), Ibahernando (Cáceres, CPIL 283), Coria (CIL II 427) e Beja (ILER 6240), era ainda desconhecido no conventus escalabitano. Derivado em anus de Marcius (139), Marcianus, é um cognome latino $\left({ }^{140}\right)$, segundo Kajanto raramente usado por escravos e libertos (141). Relativamente frequente na Hispania (mapa II), principalmente no litoral, onde Tarragona reúne o maior número de testemunhos (CIL II 4118, 4122/4259, 4182, 9111; RIT 398, 589) surge não poucas vezes associado a onomástica de origem grega, como sucede, por exemplo, em epígrafes de Ralsa (CIL II 5161), Évora (142) e Lisboa (CIL II 4998). Tal facto, já de si indicador de uma situação sócio-cultural especial, é ainda destacado pela adesão de indivíduos portadores deste cognome a formas culturais tão específicas como os cultos greco-orientais. A inscrição eborense de T. Caicus Marcianus, membro de uma associação de fiéis da deusa

(135) Paulys Realencyclopädie der Classischen Altertumswissenchaft, (e.r.), 16, Estugarda, 1958, p. 2057-2058.

(136) Cagnat, p. 53.

(137) KaJanto, Cognomina, p. 18, 278.

(138) ILER, p. 267.

(139) Schulze, p. 466; H. Thylander, Étude sur VÉpigraphie Latine, Lund, 1952, p. 113-114; ILER, p. 716-717.

(140) Kajanto, Cognomina, p. 27, 35.

(141) KaJanto, Cognomina, p. 150.

(142) José D'EnCARnaÇấ, Notas sobre epigrafia romana de Évora, «Humanitas», XXIX-XXX, 1977-1978, p. 83-85, n. ${ }^{\circ} 4$ (^ENCARnaÇão, Évora). Haverá relação entre as aras funerárias e a onomástica grega? 
grega Némésis (CIL II 5191), os amici Nemesiaci, faculta um excelente testemunho dessa adesão, reveladora de incontestáveis influências culturais mediterrânicas, helenísticas, a que já aludimos neste artigo (n. ${ }^{\circ}$ ), bem como de uma situação social em que nitidamente transparecem laços com os liberti (143), ainda que juridicamente já ultrapassados. A seguinte passagem de Tácito não é menos reveladora: Nec minor gratia Icelo, Galbae liberto quem anulis donatum equestri nomine Marcianum cognomine ornatus $\left({ }^{144}\right)$. Na Lusitânia, o cognome Marcianus foi registado com certa frequência no conventus Pacense (145), em Cadafais (CIL II 288) e em duas esclarecedoras inscrições de Lisboa: Matidiaej

I Aug I Fel . Iul . Olisipo / per Q . Antonium Galium / T. Marcium Marcianum / Ilvir (CIL II 4993); D . M j M . Cassi... / Marciani I an. XX I I I Annia j Corinthia / nepoti / pio (CIL II 4998). Quanto ao cognome latino Potitus (146), relacionado com uma importante família patrícia, ligada desde o século iv a.C. ao culto de Hércules, em Roma $\left({ }^{147}\right)$, tem fraca representação na Hispânia (anexo II), onde quase repete a distribuição do cognome Marcianus. Até agora, abstraindo das marcas cerâmicas, foi assinalado em Várzea do Douro (CIL II 2377), Arroyo de la Luz (Cáceres, ILER 6426), Mérida (ILER 3666), Sevilha (CIL

II 1172), Adra (Almeria, CIL II 1990), Liria (CIL II 3796, 3799), Vivei (Castellón, CIL II 4006) e Tarragona (ILER 4328). Há ainda um Potitianus em Itálica (ILER 3419). A análise das epígrafes referidas fornece alguns elementos interessantes, nomeadamente o grupo de quatro em que a referência à tribo, a Galéria, exprime inequivocamente a cidadania (CIL II 3799, 4006; ILER 3666, 4328): três destas incluem onomástica registada nas inscrições torrienses (CIL II 3799; ILER 3666, 4328); uma delas insere um cognome grego feminino (ILER 4328).

A análise antroponimica permite afirmar que estamos perante elementos estranhos à população indígena: distribuição e qualidade

(143) AlarCão, Portugal, p. 172-175.

(144) TÁcıto, Hist., 7, 13.

(145) ENCARNAÇ̃̃o, Évora, p. 85.

(146) KaJanto, Cognomina, p. 354.

(14?) Paulys Realencyclopãdie, (e. r.), 43, 1953, p. 1183-1186. 
dos cognomina assim o sugerem francamente. A presença dos tria nomina e da filiação indica tratar-se de cidadãos latinos ingenuii ${ }^{448}$ ). Todavia, o cognome grego de Q. Bóvio Atimecião Vítor, aliado ao lapso verificado no final da denominação de Q. B. Marciano suscita reticencias quanto à filiação de Atimecião: será filho ou liberto de Marciano? Considerar este como patrono é hipótese a ter em consideração, mas pela qual não optamos, tendo em conta os dados disponíveis, nomeadamente a repetida indicação, na região olisiponense, da situação de servo ou liberto — só por excepção incluída depois do cognome $\left({ }^{149}\right)$ - mesmo quando se não indica o nome do dono ou patrono $\left(15^{\circ}\right)$, o qual só ocorre plenamente desenvolvido numa inscrição de Lisboa (CIL II 216) e numa outra, aliás de leitura duvidosa, proveniente de Lameiras (CIL II 265). Por outro lado, é possível que a filiação através dos tria nomina visasse destacar a origem livre de Atimetio, uma vez que o seu cognome grego, sem denunciar obrigatoriamente um passado servil ( ${ }^{(51)}$, poderia levantar suspeitas, visto que a onomástica helénica, frequente no conventus pacense e em Lisboa $\left({ }^{152}\right)$, se situa em grande parte num ambiente de libertos $\left({ }^{153}\right)$, com os quais parece possível relacionar os Bovii torrienses. A sua presença nesta região reflecte a influência do grande porto do Tejo sobre o vasto território rural olisiponense, confirmada, ao nível da ordo decurionum, pela inscrição da Serra de S. Julião (n. $\left.{ }^{\circ} 12\right)$.

A menção da idade, por razões de ordem psicológica, é — ou parece - mais frequente nos epitáfios de pessoas jovens (154). Uma reacção semelhante, relacionada com a média de vida, não conduziria a destacar os casos de longevidade?

(148) Alföldy, Notes, p. 51; P. LE Roux/G. Fabre, Inscriptions latines du Musée de Coimbra, «Conimbriga», 10, 1971, p. 129.

(149) Cagnat, p. 8.

$\left(1^{\circ}\right)$ Cardozo, Catálogo, p. 63-64, n. $\left.{ }^{\circ} \mathrm{XV}\right)$.

(151) F. G. MAIER, Römische Bevölkerungsgeschichte und Inschriftenstatistik, «Historia», 1954, p. 341-344.

(152) F. Bandeira Ferreira, Varia Epigraphica, «Revista da Faculdade de Letras», III, 2, 1958, p. 158-161; Vieira Da Silva, p. 276-283.

(153) KaJanto, Non-Latin Cognomina, p. 519-529.

(154) L. HE NRY, L'âge au décès dans les inscriptions funéraires, «Population», 1959, p. 327-329.

Conimbriga, 21 (1982), 5-99 
A expressão PATRI OPTVMO, muito vulgar, encontra-se largamente documentada. A troca do $\mathrm{I}$ por $\mathrm{V}$, repetida noutras epígrafes regionais (n. $\left.{ }^{\circ} 7,12\right)$, exprime a pronúncia $(155)$, ocorrendo, inclusive, em inscrições monumentais importantes, como a do arco de Augusto (CIL V 7231), em Susa, na Itália.

\section{d) Datação}

O uso do dativo e do adjectivo optumo, a indicação da idade, a tendência para valorizar o cognome, a paleografia, levam-nos a datar esta inscrição do final do século n.

\section{7-QUINTA DA MACHEIA. Foto 8}

\section{d) Descrição}

Pedestal funerário monumental, de calcário lioz, encontrado em 1959 a cerca de uma centena de metros da casa principal da Quinta da Macheia, freguesia de Matacães, Torres Vedras. É um monumento imponente, austero, em forma de paralelipípedo ; os lados foram meticulosamente alisados. Muito bem conservado, mostra nos flancos dois grandes entalhos em forma de cauda de andorinha, idênticos e simétricos, relacionados, segundo nos parece, com uma reutilização do pedestal como peso numa prensa de lagar, ainda em época romana $)^{156}$ ). O campo epigráfico ocupa quase toda a superfície da face que contém a inscrição, cujas oito linhas se concentram na metade superior; a base da última linha corresponde precisamente à divisória entre as duas metades;

(155) M. Niedermann, Phonétique historique du Latin, Paris, 1953, p. $18-19$.

(156) Camps-Fabrer, p. 47, pi. VII, p. 62, pi. XVI; M. Christofle, Essai de restitution d'un moulin à huile de l'époque romaine à Madaure, Argel, 1930, p. 12, 40, flg. 17, p. 67-69; Mendes de Almeida/Bandeira Ferreira，Varia，LXXVI，3-4，1966，p. 341，fot. 3; Ponsich， p. 380, fot. LXXXIV. Não é impossível, contudo, que os entalhos se relacionem com a fixação da imago referida na inscrição. 
o espaço compreendido entre as 1.1 e 8 é igual ao que se desenvolve inferiormente a esta, até à base em que se encasava o monumento.

Dimensões: 124x59x57. Campo epigráfico: 111×59.

LICINIA . P (ublii) . F (ilia) . MAXS/VMA . M \{arcus) ANTISTI/VS . M (arci) . F (ilius) . GAL(ma tribu). FACVND/VS . H (ic) . S (iti). S (um) $1^{5}$ CORNELIA . T (iti) . F (ilia). BOYTIA / QVIVS . POSITA . EST / IN PRIMA . PARTE . IMA/GO . VIVA . SE . $\mathrm{F}$ (aciendum) . C(uravit)

Licinia Máxima, filha de Públio, e Marco Antístio Facundo, filho de Marco, da tribo Galéria, estão aqui sepultados. Cornélia Búcia, filha de Tito, cujo retrato está colocado na parte superior, mandou em sua vida fazer (este monumento).

Altura das letras: 1. 1: 5,5; 1. 2: 5,3 $(\mathrm{T}=6) ; 1.3: 5,3(\mathrm{~V}-4,8$ $\mathrm{M}$ intercalado $=1,5 ; \mathrm{F}$ intercalado $=\mathrm{C} 2) ; 1$. 4: 5,3; I. 5: 4,5 $(\mathrm{T}=4,8$; B, 2.0 O, F=4,2); 1. 6: 4,6 $(0=4,3) ; 1$. $7: 3,7 \quad(\mathrm{~T}=4,2) ; 1$. 8: 4 . Espaços: $1: 11 ; 2: 2 ; 3: 1,6 ; 4: 2 ; 5: 1,6 ; 6: 1,7 ; 7: 1 ; 8: 1,2 ; 9: 64$.

\section{b) Bibliografia e variantes}

Belo, «Badaladas», 230, 1959 (foto); transcrito em «Conimbriga», I, 1959, p. 157; Almeida/Ferreira, Varia, LXXVI, 3-4, 1966, p. 341-343 (fotos); Vives cita o artigo da «Revista de Guimarães» sem o utilizar (ILER, p. 823).

1.1: pontuação incorrecta (BELO; «Conimbriga»).

1. 3: VS . CAL . FACVND (Belo; «Conimbriga»), VS . F . GAL . FACVND (Almeida/Ferreira).

1.4: pontuação incorrecta (BELo; «Conimbriga»).

1.5: BOVTI (Belo; «Conimbriga»; Almeida/Ferreira).

1.6: pontuação incorrecta, N (BELo; «Conimbriga»).

1.8: pontuação incorrecta (BELO; «Conimbriga»). 


\section{c) Comentário}

O ordinator e o lapidarius executaram neste notável monumento um trabalho de responsabilidade. Contudo, a paginação resultou muito cerrada e um pouco confusa, devido certamente à necessidade de compartimentar a inscrição, atendendo à natureza do suporte. A economia do texto é, no fundamental, clássica, mas a ordinatio que a traduz está longe de ser exemplar: verifica-se corte de palavras em quase todas as translineações, nomeadamente no final da 1. 1 o corte do cognome Maxsuma e logo na 1.2 o do gentilicio Antistius; na 1. 4 há um desequilíbrio sensível na distribuição das letras, sacrificadas a um alinhamento à esquerda resultante da omissão na 1.3 das siglas $\mathrm{M}$ e $\mathrm{F}$; no final da 1.5 foi incluído um pequeno A para evitar o corte do cognome da construtora do monumento. A ausência de nexos, que se multiplicaram depois de Augusto, sugere desde logo uma datação alta. $\mathrm{O}$ alinhamento, à esquerda e à direita, é flexível. As linhas foram cuidadosamente guiadas por dois traços auxiliares paralelos, que é necessário subentender. Puncti distinguentes de forma triangular, usados com generosa sobriedade; entre as siglas intercaladas há um pequeno ponto circular. A escrita é do tipo capital quadrada, de boa gravação em bisel, com um ductus francamente vertical, salvo uma ou outra hesitação. Pequenos ápices marcam as extremidades das letras; destacam-se, porém, pelo desenho e dimensões, os remates do S. Os travessões são todos horizontais, tendo recebido um tratamento especial os do $\mathrm{T}$, letra que sobressai sistematicamente das restantes. São de bom recorte o $\mathrm{C}, \mathrm{O}, \mathrm{Q}$ e $\mathrm{G}$, próprios do século $\mathrm{i}$; $\mathrm{P}$ aberto, $\mathrm{R}$ executado a partir do $\mathrm{P}$, com a haste oblíqua recta; o $\mathrm{N}$ inscreve-se perfeitamente num quadrado $\mathrm{e}$ ostenta apenas dois ápices; o A tem a forma de um triângulo isósceles; o $\mathrm{M}$ é muito aberto, com o ângulo inferior bem desenhado; o desenho do S é irregular e o D tem pança semicircular.

A leitura da inscrição não suscita problemas complicados. Entre o primeiro $\mathrm{M}$ da 1.2 e o $\mathrm{S}$ da 1.3 é perfeitamente visível um pequeno $\mathrm{M}$; envolvido pela parte inferior do primeiro $\mathrm{A}$ da 1.2 destaca-se com grande nitidez um $\mathrm{F}$ reduzido; no final da 1.5 subsiste parte de um pequeno A; finalmente, no início da 1.7 restam vestígios de um I representado pelos ápices. Mendes de 
Almeida e Bandeira Ferreira não detectaram o $M$ intercalado, nem o A da 1. 5 e consideraram a grafia Botiti corno um lapso ortográfico, subentendendo o I da 1. 7. Assim, a sua tentativa de interpretação da 1. 3 - YS . [G.] F[.] GAL — revela-se inviável e desnecessária. Nenhuma das quatro letras acima referidas foi registada por Ricardo Belo, lapso que se repete, naturalmente, na nota da revista «Conimbriga».

Licinia Maxsuma era, como prova a indicação do nome do pai, ingenua. A precedência que lhe foi atribuída na identificação revela um procedimento não totalmente regular $\left({ }^{157}\right)$, relativamente documentado na região a norte do estuário do Tejo (CIL II 268, 290 293). O gentilicio Licinius apesar de raro no Centro e Norte da Lusitânia conta com numerosos testemunhos na Hispânia ( $\left.{ }^{158}\right)$, nomeadamente em Lisboa $\left({ }^{159}\right)$ e na zona de Sintra $\left(1^{\circ}\right)$; perto de Torres Vedras ocorre numa inscrição de Aldeia Gavinha (n. ${ }^{\circ} 13=$ $=C I L$ II 308). Extremamente raro entre libertos (161), o vulgaríssimo cognome latino, Maximus, a, situado por Kajanto no grupo dos cognomina protectores $\left({ }^{162}\right)$, é muito frequente na epigrafia peninsular, como se pode ver pelos índices do CIL e do ILER.

A forma Maxsuma contém dois elementos arcaizantes: a utilização do grupo XS por X e a grafia em V da vogal apofónica $\left({ }^{163}\right)$, esta igualmente registada nas fórmulas dedicatórias de duas inscrições conservadas no Museu (n. ${ }^{\circ}$ 6, 12). Estaremos perante uma manifestação de compreensível fatuidade ? As formas Masxuma e Maxima podem coexistir (164). Totalmente latino, o nome do cidadão $M$. Antistius Facundus compreende um gentilicio pouco vulgar $\left({ }^{165}\right)$, usado por uma gens com personagens

(157) CAGNAT, p. 292.

(158) ILER, p. 711; KNAPP, p. 217.

(159) VIEIRA DA SILVA, p. 280-281.

(160) FONTES, p. 32-35.

(161) KaJAnTo, Cognomina, p. 275-276; A. M. DufF, Freedmen in the early Roman Empire, Cambridge, 1958, p. 58.

(162) KaJanto, Cognomina, p. 29.

(163) NIERDERMANN, p. 18.

(164) J. B. MoreIRA, Duas inscrições funerárias romanas na igreja de S. Lourenço dos Francos, «Conimbriga», XV, 1976, p. 130.

(165) Schulze, p. 124; Thesaurus, II, 1906, p. 190. 
de elevada posição sócio-económica, incluindo senadores e cavaleiros (PIR 753, 777), a qual teve na Hispânia como principal representante o legado de Augusto G. Antistius Vetus, experiente general vencedor dos Cantabros em Aracillum (166). A Lusitânia reúne parte importante dos muito dispersos testemunhos peninsulares (mapa III), entre os quais destacaremos Antistia Maela, em Lisboa (CIL II 4996), Manius Antistius Agripinus, em Tentúgal (167) e L. Antestius Persicus, duúnviro e pontífice perpétuo, em Mérida(168). Antistiana era o nome de uma estação da via Cádis/Roma, situada a vinte e nove milhas romanas de Tarragona (ILER 1779), cidade onde duas inscrições referem a gens Antistia (CIL II 4324; RIT 507); numa tessera hospitalis proveniente de Sasamón (Burgos, CIL II 5812), o gentilicio ocorre, mais uma vez sob a forma feminina, associado com outros antropónimos referenciados na região torriense. O cognome Facundus deriva do adjectivo homónimo e é extremamente raro na Península, onde apenas se conhecem mais cinco exemplos, registados respectivamente em marcas cerâmicas de Tarragona (CIL li 496935, 4970 ${ }^{185}$ ) e em inscrições de Córdova (CIL II 2294; ILER 6833) e Villagorda, perto de Jaén (CIL II 3326). Considerando as características gerais do monumento, que sugerem abertamente uma datação recuada, é provável que se trate de um emigrante ou descendente de emigrantes de origem itálica. Todavia, apesar de não ser possível relacioná-lo concretamente com Cornelia Routia, há que ter em conta uma ligação estreita com as camadas superiores da população indígena romanizada, ligação também nitidamente evidenciada pelo cognome Maela presente na epígrafe lisboeta $\left({ }^{169}\right)$. O gentilicio Cornelia reflecte, possivelmente, antigas relações de clientela com alguma das prestigiosas figuras que $o$ introduziram na Hispânia, onde é muito vulgar $\left({ }^{170}\right)$, mas de distribuição irregular. Na zona entre o Tejo e o Atlântico tem

(166) Floro, II, 33, 51; Dião Cassio LUI, 25, 7.

(167) Fouilles, p. 57-58, n. ${ }^{\circ} 30$.

(168) J. F. MARTIN, LOS magistrados municipales en Lusitania durante el Alto-Imperio, «Memorias de Historia Antigua», I, 1977, p. 232-233.

(169) UntermanN, p. 129-130, mapa 52.

$\left(1^{\circ}\right) I L E R$, p. 682-684; KNAPP, p. 194, $212,221$. 
fraca representação: apenas foi assinalado em Lisboa (CIL II 211, 5001) e perto de Sintra $\left({ }^{171}\right)$. No conventus pacense a falta de representatividade quantitativa é compensada pela qualidade dos testemunhos, que incluem o sevir ossonobense M. Cornelius Eridanus (CIL II 2) e o tribuno da Legio III Augusta e flàmine provincial L. Cornelius Bocchus, recordado em inscrições de Tróia (CIL II 5184) e de Alcácer do Sal (CIL II 35); citaremos ainda uma excelente placa funerária da Graça do Divor, Évora, por mencionar duas representantes femininas das gentes Cornélia e Valéria usando, respectivamente, os cognomes Maxuma e Amoena (172), significativamente presentes na epigrafia torriense. Boutia é um antropònimo típico da área indo-europeia peninsular, especialmente bem representado na região lusitana oriental, onde se situaria o seu centro de difusão $\left({ }^{173}\right)$; poderá ter como raiz o céltico *blioudhi — vitória $\left({ }^{174}\right)$. $\mathrm{Na}$ zona atlântica do conventus escalabitano foi registado em Conímbriga $\left({ }^{175}\right)$, no termo de Sintra $\left({ }^{176}\right)$, onde uma das epígrafes refere uma mulher de nascimento livre denominada Licinia Boutia $\left({ }^{177}\right)$ e, na região torriense, nesta inscrição da Quinta da Macheia; no conventus pacense encontramo-lo em Montemor-o-Novo (CIL II 123), Alcácer do Sal (CIL II 5182) e Panóias, perto de Ourique (178). Poderá ocorrer em epígrafes de Maceira (CIL II 343) e Messejana $\left({ }^{179}\right)$, assim como na cupa da Praia de Santa

(171) Fontes, p. 33, n. ${ }^{\circ}$ IX.

(172) ENCARNAÇão, Évora, p. 80-83, n. ${ }^{\circ} 3$.

(173) Untermann, p. 72-73, mapa 15 ; Albertos, Antropónimos, XXXII, 2, 1964, p. 231.

(174) M. L. Albertos, La onomástica personal primitiva de Hispania Tarraconense y Letica, Salamanca, 1966, p. 60-61 ( = Albertos, Onomástica); M. Palomar La Pesa, La onomástica personal pre-latina de la antigua Lusitania, Salamanca, 1957, p. 50-51.

(175) Fouilles, p. 78, n. ${ }^{\circ}$ 51, p. 180-181, n. ${ }^{\circ} 394$.

(176) FonTES, p. 32-3.5

(177) Cardozo, Inscrições, p. 14, n. ${ }^{\circ} 5$.

(178) J. Leite de VAsconcelos, Inscrição romana de Panóias, «O Archeologo Português», XIII, 1908, p. 283-284.

(179) José D'EnCARnaÇấo, Estelas romanas inéditas do Sudoeste alentejano, «Conimbriga», XVII, 1978, p. 46-47, fot. 3 (= Encarnaç̃̃o, Sudoeste). 
Cruz $\left({ }^{18^{\circ}}\right)$, monumento que nos dá a conhecer uma Caecilia Max uma, filha de Julia Boiitia ( ?).

A fórmula VIVA. SE . F . C, embora pouco vulgar, não é rara: perto de Lisboa foi assinalada, com ligeiras variantes, no epitáfio do aquilifer Flávio Quadrado (CIL II 266). A inclusão da expressão «mandou fazer em sua vida» permite deduzir que Cornelia Boutia repousou igualmente na sepultura decorada com a sua imagem, assim se explicando um facto aparentemente estranho (181). Não podemos calcular com exactidão qual o tipo de imagem referida no texto, tanto mais que as pedras funerárias com representações esculturadas, de estilo clássico, parece terem sido raras na Lusitânia (la2). Ainda assim, basta a alusão à desaparecida imago para conferir a este monumento um lugar especial entre os que chegaram até nós, alusão que, por si só, permite atribuir a um estrato social privilegiado as pessoas nele referidas, representantes do grupo produzido pela fusão de elementos romanos com a elite indígena assimilada, grupo que constituiu durante o Alto-Império um dos mais activos e seguros difusores da romanidade e da ideia imperial.

Ressalvando a qualidade da execução, o tipo de letra patente nesta inscrição é idêntico ao que ocorre na célebre epígrafe de Idanha-a-Velha que comemora a oferta de um relógio de sol à capital dos Igaeditani, no ano 16 a.C. $\left({ }^{183}\right)$. Esta coincidência não só auxilia a datar aproximadamente o pedestal da Quinta da Macheia, como proporciona um padrão aferidor da qualidade da romanização, no dealbar do século i, no interior da Lusitânia e nas regiões adjacentes aos grandes centros do litoral, contrastando cruamente a rusticidade do monumento público da Civitas Igaeditanorum e o cuidadoso acabamento de um monumento particular proveniente de uma villa do territorium olisiponense.

A Quinta da Macheia situa-se numa zona onde os vestígios da implantação rural romana atingem notável densidade, relacionada com as qualidades agrícolas dos solos locais e com as

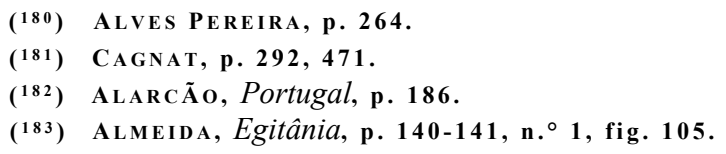


antigas vias de comunicação. Uma parte importante dos vestígios registados consiste nas necrópoles praticamente inexploradas e muito destruídas da Macheia, Juncai, Moirinha e Portucheira (184)*

\section{d) Datação}

O tipo de letra, a ausência de nexos e o recurso a caracteres retraídos, a falta de invocação aos deuses Manes, o uso do nominativo, a extrema simplicidade do formulário e a omissão de idades, permitem atribuir este importante monumento à primeira metade do século $i$.

g- QUINTA DO JUNCAL. Foto 9

\section{a) Descrição}

Placa funerária quadrangular, de calcário lioz, encontrada em 1859 nas cercanias da casa de habitação da Quinta do Juncai, freguesia de Matacães, Torres Vedras. De execução singela e regularmente cuidada, a placa, que sofreu fracturas importantes nas orlas esquerda e inferior, com consequências graves para a última linha da inscrição, encontra-se presentemente fixada numa das paredes da sala de epigrafia do Museu. O campo epigráfico, ligeiramente rebaixado, é envolvido por uma moldura simples, de filete exterior, sem diagonais e dotada de um astràgalo suplementar.

Dimensões: 39x39x5,5( ?). Campo epigráfico: 27x27(?).

D (is) . M(anibus) . Q(uinto) . IVLI/O . Q (uinti) . F (ilio) . GAL \{evia tribu). FR/ONTONI . AN(norum). / XVII . IVLIA/5 QVINTILLA MAT(er) . F(aciendum) C\{aravit)

(184) Torres, p. 21, 23.

Conimbriga, 21 (1982), 5-99 
Aos deuses Manes. A Quinto Júlio Frontão, filho de Quinto, da tribo Galéria, de dezassete anos de idade. A mãe, Julia Quintila, mandou fazer (este monumento).

Altura das letras: 1. 1: 3,8; 1. 2: 4,1 (0=4; $\left.\mathrm{Q}^{\wedge} 3,8\right) ; 1.3: 4$; 1. 4: 4,3 (XVII=4,1); 1. 5: $4(\mathrm{C}=1,6)$. Espaços: 1: 3; 2: 0,8; 3: 0,8; 4: 0,$6 ; 5: 0,7 ; 6: 0,7(?)$.

\section{b) Bibliografia e variantes}

Torres, p. 21; BeLO, «Badaladas», 85, 1953 (foto).

1.5: LVINTILla (Torres); torres e Belo omitem o ponto que antecede a fórmula $\mathrm{FG}$.

\section{c) Comentário}

A epígrafe apresenta uma paginação cerrada, não isenta de irregularidades provocadas pela necessidade de inserir um texto relativamente extenso, impecavelmente clássico na sua concepção, numa superfície muito reduzida. Tal facto permite supor que a placa se encontrava anteriormente pronta e disponível numa oficina local, tanto mais que a moldura e o tipo de letra da inscrição funerária de Avita, conservada na parede sul da igreja de Nossa Senhora da Oliveira, em Matacães (CIL II 278), situada a poucas dezenas de metros da Quinta do Juncai, são semelhantes (185). Aliás, tendo em conta o que sobre «letreiros» e «pedras» desta igreja escreveram autores monásticos não é de todo impossível que a presente inscrição tivesse a mesma proveniência inicial ( $\left.{ }^{186}\right)$. A existência de linhas auxiliares é evidenciada pela regularidade do traçado das letras, ainda assim ligeiramente descaídas. Apesar da aparente tentativa de alinhamento executada pelo ordinator, que não conseguiu evitar o corte de palavras nas 1.1 e 2 , a inscrição parece deslizar da esquerda para a direita. Os pontos

(185) Mendes de Almeida/Bandeira Ferreira, Varia, LXXVI, 1-2, 1966, p. 33-37.

(186) Mendes de Almeida/Bandeira Ferreira, Varia, LXXYI, 1 $2_{\text {\# }}$ 1966 , p. 34-35.

Conimbriga, 21 (1982), 5-99 
de separação, utilizados correctamente, são triangulares; condicionados pelo espaço disponível, ondulam acentuadamente, ocupando posições muito variadas. O ductus é francamente irregular, variando muito a inclinação dos caracteres, deficiência particularmente visível nas 1.3 e 5 , e a gravação, nítida, não muito profunda e em bisel. A escrita é do tipo capital quadrada, degradada, com letras de tamanho nem sempre uniforme, rematadas por ápices. A influência da escrita actuaría transparece nos desgraciosos $\mathrm{O}$ e $\mathrm{Q}\left({ }^{18^{\prime}}\right)$, este com uma cauda totalmente horizontal denunciando o traçado de linhas auxiliares; o $\mathrm{N}$ hesita entre a forma clássica, patente na 1. 5, e uma forma de origem cursiva, documentada na Hispânia pelo menos desde o século n ( $\left.{ }^{188}\right)$. $\mathrm{O}$ grande $\mathrm{G}$ da 1. 2, claramente destinado a valorizar a referência à tribo Galéria, é a letra mais trabalhada da epígrafe; destaca-se, sobretudo, pelo desenho invulgar do pequeno segmento vertical, assinalado, por exemplo, em inscrições de Merida (189) e de Conímbriga $\left({ }^{19 \circ}\right)$, ambas do século $\mathrm{n}$. Notaremos ainda: $\mathrm{R}$ com as extremidades da pança e da haste oblíqua, recta, coincidentes, quase tocando a haste vertical; $\mathrm{L}, \mathrm{T}$ e $\mathrm{F}$ com os travessões horizontais rigorosamente rectos $\mathrm{e}$, no caso do $\mathrm{F}$, ressalvando a excepção cursiva, da 1. 5, idênticos; D deselegante, frequente em inscrições dos séculos $\mathrm{n}$ e $\mathrm{m}$; os vértices do $\mathrm{M}$ e do $\mathrm{A}$ terminam em ápices horizontais. Destacaremos ainda a ausência de nexos e a pequena letra $G$ que encerra a última linha, na qual não nos parece possível 1er um cognome diferente de QVINTILLA.

$\mathrm{O}$ texto não apresenta conteúdo excepcional mas elucida-nos sobre o estatuto social de uma família que situaremos, certamente sem grandes probabilidades de erro, entre as que compartilhavam a posse dos campos torrienses. Os antropónimos presentes na epígrafe da Quinta do Juncai são exclusivamente latinos, pelo que poderemos estar em presença de elementos de origem itálica.

(187) CAGNAT, p. 307.

(188) Fouilles, p. 28-30, n. ${ }^{\circ} 10$, pi. II.

(189) M. A. BAscr, Antigüedades de Merida en el Museu Arqueológico Nacional, «Actas del Bimilenario de Merida», Madrid, 1976, p. 131, lam. XLVIIIc.

(190) Fouilles, p. 53-64, n. ${ }^{\circ}$ 26, p. VIII. 
$\mathrm{O}$ relevo conferido à abreviatura GAL, porém, tanto poderá reílectir o orgulho de uma família não indígena, ligada à gens Julia, por uma cidadania de raiz, como, pelo contrário, indicar uma concessão relativamente recente. $\mathrm{O}$ cognome romano Fronto (191), muito misturado com a antroponimia indígena, encontra-se bem representado na Hispânia Ocidental e Mediterránea (192), especialmente em Tarragona ( $C U^{\wedge}$ II 1316, 4136, 4139, 4255, 4256; ILER 1317, 4428, 6363). Deriva, com numerosas variantes, de frons e foi utilizado, indiscriminadamente, como cognome, como gentilicio (CIL II 5256) e como nome individual (CIL II 5875). $\mathrm{Na}$ Lusitânia, para além de Matacães, foi registado em Viseu (CIL II 406), Conímbriga (193), Penacova (CIL II 6275a), Mileu (Guarda, ILER 4577), Idanha-a-Velha (CIL II 450; ILER 4699, 4855, 5215), Hinojosa del Duero (ILER 2857), Casillas (CIL II 798), Villamiel (ILER 2722), Coria (CIL II 772), Leiria (CIL II 345), Almourol (CIL II 6271), Villar (CIL II 844), Torre de D. Miguel (CIL II 754), Torremenga (ILER 939), Oliva (CIL II 836), Mérida ( ILE $R$ 6412), Badajoz (ILER 3601), Loulé (CIL II 5135) e, ainda, numa inscrição de origem incerta, talvez de Évora (CIL II 73), assim como, de forma dubitativa, num fragmento de lintel encontrado na mesma cidade (194). Quintilla, uma das muito difundidas variantes femininas de Quintus (195), é um cognome relativamente habitual na epigrafia hispano-romana, com notável representação na Lusitânia, nomeadamente na região olisiponense, onde o testemimho da Quinta do Juncai é acompanhado por outros registados em S. Miguel de Odrinhas (CIL II 267) e Lisboa (CIL II 245; ILER 4759). No conventus escalabitano foi assinalado em Valado, perto de Alcobaça, numa ara consagrada a

(191) Kajanto, Cognomina, p. 17，26，118，236; J. Perin, Lexicon Totius Latinitatis, V, Pavia, 1940, p. 643.

(192) J. Rubio Alija, Españoles por los caminos del Imperio Romano (Estudios epigráfico-onomásticos en torno a Reburrus y Reburrinus), «Cuadernos de Historia de España», XXIX-XXX, 1959, p. 22, mapa 5; N. Correia Borges, Noca leitura da inscrição CIL II 6275a, "Conimbriga», XV, 1976, p. 123-124, mapa 2.

(193) Fouilles, p. 79-80, n. ${ }^{\circ}$ 52, pi. XII, p. 138, n. ${ }^{\circ}$ 300a,b.

(194) ENCARNAÇão, Évora, p. 75-77, n. ${ }^{\circ} 1$.

(195) KaJanto, Cognomina, p. 78. 
Minerva em memória de uma Carisia Quintilla (CIL II 3ol), e na área de Collipo (196); está igualmente presente em Idanha-a- Velha (ILER 2691). No conventus emeritense foi registado em Mérida (CIL II 571) e em Cáceres (ILER 1528), cidade onde ocorre uma Iulia Quintilla, mulher do edil e duúnviro Q. Norbanus Capito, enquanto que no conventus pacense foi referenciado em inscrições provenientes da Herdade da Silveirona, nos arredores de Estremoz (197), e de Beja, esta referindo uma outra Iulia Quintilla, dita Eborensis (CIL II 5187).

De uma maneira geral os testemunhos relacionam-se com um meio social e cultural profundamente romanizado, situando-se grande parte deles num ambiente rural onde o estabelecimento de colonos itálicos correspondeu certamente a uma realidade; outros, como sugere o perfil da distribuição no território lusitano, poderão reflectir actividades administrativas, militares ou mineiras.

As fórmulas utilizadas na inscrição são muito simples e vulgaríssimas; D.M. resulta da simplificação da fórmula primitiva, não anterior, na Hispânia, ao final do século i ( $\left.{ }^{198}\right)$.

d) Datação

A paleografia, a invocação aos deuses Manes, abreviada, o uso do dativo e a indicação da idade apontam francamente para a segunda metade do século II.

9 _ QUINTA DA PORTUCHEIRA. Foto 10

a) Descrição

Esteia funerária de arenito, de topo semicircular, proveniente de uma das sepulturas de inumação descobertas em 1930

(196) D. Domingos de Pinho Brandão, Epigrafia romana coliponense, «Conimbriga», XI, 1972, p. 142.

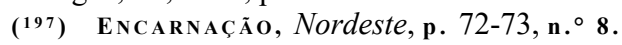

(198) THYLANDER, p. 56-57.

Conimbriga, 21 (1982), 5-99 
junto à casa da Quinta da Portucheira, freguesia de Matacães, Torres Vedras. O aspecto geral do monumento, que se encontra em bom estado, é rude mas equilibrado. 0 termo inferior gasto $\mathrm{e}$ pequenas falhas no canto direito não prejudicam a inscrição. A face principal, bordada por um filete quase desaparecido na base, comporta três campos distintos: o campo superior ostenta um arco em contrafilete e uma rosácea cruciforme, em relevo, inscrita num círculo rebaixado, ladeado por dois duplos círculos concéntricos. A zona intermédia da estela corresponde ao campo epigráfico, ocupando a inscrição três cartelas rectangulares rebaixadas, sensivelmente descaídas sobre a direita; o campo inferior é decorado com um motivo em forma de segmento de coroa circular, cujas extremidades se apoiavam na fracção obliterada do filete, lateralmente sobrepujado por dois círculos concêntricos semelhantes aos do campo superior e envolvendo um traço horizontal interrompido. $\mathrm{O}$ dorso é sumariamente afeiçoado.

Dimensões: 93x70x15,5. Campo epigráfico: 40x59. Cartelas: $9,5 \times 49 ; 9,5 \times 47 ; 9,5 \times 46$.

\section{REBVRRVS . / TVSCI . F (Mus) . ET / TVSCA . TVSCIF(¿M}

Reburro, filho de Tusco, e Tusca, filha de Tusco (estão aqui sepultados).

Altura das letras: 1. 1: 7,5; 1. 2: 7,5; 1. 3: 7/7,5 (IF: 1=9; $\mathrm{F}=\sim-6,5)$. Espaços entre as cartelas: 5,5.

\section{b) Bibliografia e variantes}

Belo, «Badaladas», 143, 144, 1956; Belo, Símbolos, p. 43, 55 (desenho).

\section{c) Comentário}

Entre o espolio, largamente destruido e disperso, da Quinta da Portucheira, a presente estela ocupa um lugar especial, quer por representar elucidativamente uma certa realidade 
sócio-cultural indígena subjacente numa região onde a adesão à romanidade foi nítida e rápida, quer por ter sido registada, embora de forma duvidosa, uma parte do contexto em que se integrava. Com o presente monumento foi descoberta uma segunda lápida, (n. ${ }^{\circ}$ 10), também publicada por Ricardo Belo $\left({ }^{199}\right)$. Não obstante grande parte do material recolhido no local, nomeadamente as lucernas $\left({ }^{20}\right)$, sugerir uma datação tardia, as características francamente arcaicas do monumento favorecem a hipótese de se tratar de uma reutilização. Ricardo Belo refere como tendo sido encontrados «na mesma ocasião» alguns tijolos de curioso recorte, conservados no Museu, e uma lucerna, entretanto extraviada (201). Todavia estes elementos não são suficientes para resolver o problema: os tijolos, apesar de integrados na sepultura, não asseguram qualquer datação; quanto à lucerna, datável da primeira metade do século $\mathrm{m}$ e ostentando uma marca com palma referenciada noutros locais da Lusitânia ${ }^{202}$ ), inclusive, embora sem a sigla AL, numa peça encontrada no mercado de Torres Vedras $\left({ }^{203}\right)$, nada garante ter pertencido ao espólio em causa, o que, a ter-se verificado, não invalidaria uma quase certa reutilização da pedra, prática aparentemente generalizada a partir de meados do século III(204); por essa mesma época começa a difundir-se na Lusitânia o rito da inumação, aliás já anteriormente utilizado $\left(2^{\circ} \tilde{o}\right)$.

A paginação, sem palavras cortadas, denota um certo cuidado. O texto, alinhado à esquerda e à direita, distribui-se equilibra-

(199) Belo, «Badaladas», 101, 1954.

$\left(2{ }^{\circ}\right)$ Leonel Trindade/Veiga Ferreira, Objectos, p. 266-269.

(201) A. RiCARDo BELO, Jsótulas sobre quatro lucernas romanas de barro, inéditas, «Boletim da Junta de Província da Estremadura», p. 50-52, 1959, p. 105-107, est. II, 3.

(202) Adilia M. Alarcão/Salete da Ponte, As lucernas romanas do Paço Ducal de Vila Viçosa, «Conimbriga», XV, 1976, p. 76-77, 82-83, est. Ill, VII.

$\left(2^{\circ} 3\right)$ Leonel Trindade/Veiga Ferreira, Objectos, p. 266, est. Ill, 5.

(204) S. Mroze K, À propos de la répartition chronologique des inscriptions latines dans VHaut-Empire, «Epigraphica», XXXV, 1-2, 1973, p. 118.

$\left(2^{\circ} 5\right)$ Alarcão, Portugal, p. 183; exemplo de inumação no século ĩ: Encarnação, Sudoeste, p. 44-45, n. 2 (trata-se de urna Iulia Amoena indubitavelmente indígena). 
damente pelas três cartelas destacando, decerto de forma intencional, o antropònimo Reburrus, isolando-o na 1. 1, preterindo a identificação de Tusca, comprimida na última linha. Pontuação circular, nem sempre necessária, como no final das 1 . 1 e 2. Os caracteres, de gravação vigorosa mas irregular, conservam reminiscências do tipo monumental e denunciam forte influência actuária e cursiva; ápices grosseiramente marcados. A pança do $\mathrm{R}$ é muito reduzida, ligada à haste vertical de forma quase imperceptível a partir do ponto onde começa a haste oblíqua, ligeiramente arqueada; o $\mathrm{B}$ apresenta panças desproporcionadas, unidas à haste vertical a dois terços da altura desta por um travessão horizontal idêntico ao do $\mathrm{R}$; o vértice do $\mathrm{V}$ é acentuadamente arredondado; o traçado do S, estreito e ondulante, é extremamente rude; os travessões do $\mathrm{E}, \mathrm{F}$ e $\mathrm{T}$ são horizontais e, no caso dos dois primeiros, idênticos entre si. Os nexos TV e IF, concentrados na 1. 3, são normais; contudo, IF destaca-se pela sua relativa raridade. Uma esteia do século i encontrada no sítio de Carvalho, perto de Odemira, faculta caracteres algo semelhantes aos do monumento da Quinta da Portucheira, o que reforça a hipótese de uma datação remota para este (206).

Um dos elementos mais interessantes desta epígrafe reside na decoração de tipo normalmente designado por astral, vulgar no Noroeste da Península $\left({ }^{207}\right)$, pouco frequente no território actualmente português abaixo de uma linha imaginária quase coincidente com o limite sudoeste do grupo Pint da onomástica indígena (208). O duplo problema da origem e possível significado de tais motivos, apesar de ampiamente debatido, encontra-se longe de uma solução geralmente aceite. Porém, quer se recorra, atendendo à sua grande dispersão geográfica e cronológica, à teoria

$\left(2^{\circ}\right.$ 6) Encarnação, Sudoeste, p. 49-50, n. ${ }^{\circ}$ 6, fot. 6.

$\left({ }^{207}\right)$ A. Garcia y Bellido, Esculturas Romanas de España y Portugal, Madrid, 1949, p. 321-327 (= GARCIA Y BELLIDo, Esculturas).

(208) Rubio Alija, p. 23, mapa 7. Parece-nos interessante que tal linha se denuncie nos mapas geológicos e linguísticos: Serviços Geológicos de Portugal, Carta geológica de Portugal (1/1000000), Lisboa, 1968; Manue L de Paiva Boleo, $O$ mapa dos dialectos e falares de Portugal, «Estudos de Linguística Portuguesa e Românica», I, Coimbra, 1974 (mapa junto à p. 352). 
das soluções idênticas para problemas idênticos, enunciada por B. Bandinella ${ }^{209}$ ), quer se lhe reconheça origem exterior, é obitòrio considerar os temas em questão indiscutivelmente anteriores à ocupação romana $\left({ }^{210}\right)$. De maior complexidade se reveste o problema do possível simbolismo desta temática vivaz, na qual os astros representariam a morada dos mortos e os arcos a entrada do Hades $\left({ }^{2 n}\right)$. Na verdade possuímos algumas referências concretas acerca de cultos siderais praticados na Hispània durante a Antiguidade mas sabemos realmente muito pouco sobre os rituais e a ideologia de tais cultos. A ideia da imortalidade celeste encontra-se expressa nalguns raros epitáfios romanos, eventualmente num tom bem tocante $\left({ }^{212}\right)$; contudo; apesar de Sílio Itálico afirmar que os Celtiberos não sepultavam os guerreiros caídos em combate para facilitar a ascenção das almas ao céu $\left({ }^{213}\right)$, a epigrafîa hispano-romana não contribuiu ainda de forma relevante para a solução do problema. Remetendo para os intermundia da investigação as hipóteses sem conteúdo, há que considerar apenas os dados disponíveis e reconhecer que as características geométricas simples da maioria das representações consideradas aconselham uma interpretação restrita que favoreça a intenção decorativa $\left({ }^{214}\right)$. Expressão gráfica de uma robusta tradição, presente na Cultura Castreja e preservada durante o período romano por grupos notavelmente conservadores (215), a temática astral, que poderá ter conhecido um certo revivalismo coincidente com o ocaso romano na Península $\left({ }^{216}\right)$, foi alvo como símbolo

(209) R. Bianchi Bandinella Storicità deVArte Classica, Bari, 1973, p. $383-385$.

$\left.\mathbf{( 2 1 0}^{\circ}\right)$ Dolores Julia, Étude épigraphique et iconographique des stèles funéraires de Vigo, Heidelberga, 1971, p. 24-27 (= Julia, Vigo).

(211) F. CUMONT, Recherches sur le symbolisme funéraire des Romains, Paris, 1942, p. 37-41; Garcia y Bellido, Esculturas, p. 336-337.

(212) R. в сосн, Épigraphie Latine, Paris, 1964, p. 65-66.

(213) Silio Itálico, III, 341-343.

(214) Julia, Vigo, p. 38; Alarcão, Portugal, p. 186, 205.

(215) Abásolo/Albertos/elorza, p. 85-87.

(216) Diego Santos, Romanización de Asturias a través de la epigrafía romana, Oviedo, 1963, p. 27-36. É significativa a cronologia baixa (séc. iii-séc. v) das lápidas cántabras datadas pela era consular: J. M. IgLesias, Onomástica prerromana en la epigrafía cántabra, Santander, 1974, p. 210-216. 
de um passado pagão, da intervenção repressiva do I concílio de Braga (217). Sobreviveu, porém, ao Götterdämmerung e, acolhida ao reduto da arte popular, à qual não era estranha, aí se manteve, provando elucidativamente a sua profunda implantação e permanente vocação decorativa. Assim, parece-nos aceitável atribuir às representações consideradas astrais um duplo valor, fazendo depender a sua qualidade decorativa ou simbólica do contexto em que se inserem. Todavia, tal conclusão não significa que alguns dos motivos, como os círculos e as rosáceas, possuam mais do que um simples valor decorativo.

Nesta esteia da Quinta da Portucheira o elemento decorativo preponderante é a rosácea cruciforme, corrente na arte castreja $\left({ }^{218}\right)$, possível representação do $\operatorname{Sol}\left({ }^{219}\right)$. Os círculos concêntricos, repetidos no campo inferior, muito vulgares no Noroeste, têm sido objecto de múltiplas interpretações, nomeadamente quando, como no caso presente, acompanham uma figura central $\left({ }^{22^{\circ}}\right)$. Quanto aos arcos dos campos superior e inferior, Ricardo Belo considerou-os, respectivamente, representações da abóbada celeste e do arco-iris, interpretações que nos parece exemplificarem perfeitamente os perigos da superinterrogação de documentos incapazes de permitirem, por si mesmos, reconstituições ideológicas (221). Quanto a nós, o arco em contrafilete não é susceptível de qualquer interpretação, funcionando apenas como limite do campo destinado a receber a decoração; o arco inferior representará a estilização, normal numa esteia, da abertura real ou simulada que, nos monumentos oikomorphos do Noroeste, constitue elemento fundamental (222).

A análise antroponimica não suscita quaisquer problemas. $\mathrm{O}$ antropònimo Reburrus $\mathrm{e}$ as suas variantes constituem o grupo mais numeroso da onomástica indígena peninsular, podendo segu-

(217) J. Leite de Vasconcelos, Ensaios Etnográficos, II, Lisboa, 1903, p. 71.

(218) Leite de Vasconcelos, Religiões, III, 1913, p. 73, fig. 36,

(219) Abásolo/Albertos/elorza, p. 69.

(220) Abásolo/Albertos/Elorza, p. 69-70.

(221) Stuart Piggott, Ancient Europe, Edimburgo, 1973, p. 229-230.

(222) Abásolo/Albertos/elorza, p. 79-84, lám. II-XXIIL 
ramente atribuir-se-lhe origem hispânica (223), embora o seu significado e etimologia não estejam ainda incontroversamente estabelecidos $(224)$. Tem importante projecção na specialmente ao longo das fronteiras renana e danubiana, na África do Norte e em Roma (CIL V 2729, 3256, 8041, 10056); uma epígrafe de Òstia informa-nos que um L. Cassius Rebut rus desempenhou nesse grande centro portuário o cargo de duúnviro XIV 413). O nome ocorre ainda sobre ânforas hispânicas (226) e em marcas de terra sigillata sud-gálica (227). Na Península, o domínio principo! do Reburrus g das suas variantes situa'se na aiea indo-europeia, sobretudo na zona entre o Tejo e o Minho (228). Na região de Lisboa foi assinalado nesta inscrição e em duas outras de S. Miguel de Odrinhas ${ }^{229}$ ), ambas referindo indivíduos profundamente romanizados. Atendendo à coincidência da localização dos Reburri com outros fenómenos culturais indígenas parece-nos extremamente interessante o seu registo nesta região $\left({ }^{23^{\circ}}\right)$. , a, é um cognome romano de sentido geográfico, derivado de um etnònimo. Invulgar entre escravos e libertos atinge a maior frequência, curiosamente, na Península: vinte e três de um total conhecido de quarenta e quatro testemunhos (231), todos provenientes da Hispânia Ulterior (232). O seu significado e a sua distribuição ao longo das bacias do Tejo, do Guadiana e do Guadalquivir reflectem, aparentemente, o estabelecimento de elementos itálicos nessas zonas, potencialmente ricas e aptas para uma intensa colonização agrícola, hipótese que a anomalia verificada na sua ocorrência quase confirma. As relações entre representantes deste grupo e a capital do Império estão, aliás, documentadas por

(223) Rubio Alija, p. 23-31, 112.

I224) Rubio Alija, p. 105-112.

(225) Rubio Alija, p. 79-104, mapa 12.

(226) Callender, p. 101, n. ${ }^{\circ} 344$, p. 344, p. 103, n. ${ }^{\circ} 362$, p. 211 , n. ${ }^{\circ} 1370(2)$.

(227) Rubio Alija, p. 99-104, mapa 13.

(228) Rubio alija, p. 49-52, mapa 9; Untermann, p. 155-156, mapa 66.

(229) Cardozo, Catálogo, p. 37-38, n. ${ }^{\circ}$ III, p. 65-66, n. ${ }^{\circ}$ XVII.

(230) Rubio Alija, p. 58-70; Garcia y Bellido, Esculturas, p. 321-322.

(231) Kajanto, Cognomina, p. 51, 188; Albertos, Onomástica, p. 240.

(232) Untermann, p. 179-180, mapa 79; KaJanto, Cognomina, p. 51. 
uma inscrição funerária proveniente de Almourol (CIL II 6271). $\mathrm{Na}$ epígrafe da Quinta da Portucheira o nome não representará mais do que um exemplo da adopção por parte da população peregrina de nomes romanos isolados, os nuda nomina, inicialmente como símbolo de adesão à Romanitas (233). O cognome e as variantes são frequentes na Lusitânia, inclusive na área do municipium olisiponense onde, por exemplo, numa cupa de S. Miguel de Odrinhas encontramos uma Licinia Tusca e um Albanius Tuscus (234); entre os numerosos testemunhos lisboetas destacaremos uma inscrição monumental em honra do imperador Cómodo referindo como co-dedicante o duúnviro M. Fulvius Tuscus (CIL II 187). Em Alenquer o cognome está igualmente bem representado (CIL II 275).

O esquema onomástico adoptado, de tipo peregrino (235), exterioriza um estatuto social pouco elevado. Por fim, tendo em conta que as mulheres conservaram prolongadamente os nomes indígenas, em consequência de uma maior vinculação ao meio tradicional, não deixa de ser interessante verificar ter sido a irmã de Reburrus a receber o nome latino do pai.

Epígrafe e decoração permitem relacionar este monumento com um ambiente social e cultural pouco evoluído, típico de uma região onde longamente coexistiram as novidades romanas e as tradições indígenas.

\section{d) Datação}

Os elementos facultados pela análise paleogràfica, pela análise interna - ausência de consagração aos deuses Manes, uso do nominativo, denominação de tipo peregrino - e pela decoração, sugerem abertamente uma datação alta: a primeira metade do século $i$.

(233) KNAPP, p. 189-190.

(234) Cardozo, Catálogo, p. 77-78, n. ${ }^{\circ}$ LXIX.

(235) Alfoldy, Notes, p. 37, 55-57.

Conimbriga, 21 (1982), 5-99 


\section{0 - QUINTA DA PORTUCHEIRA. Foto TI}

\section{a) Descrição}

Estela funerária de calcário, ligeiramente trapezoidal, encontrada em 1930, na mesma ocasião e nas mesmas circunstâncias que a epígrafe anteriormente descrita, numa necrópole situada perto da casa de habitação da Quinta da Portucheira, freguesia de Matacães, Torres Yedras. Reutilizada como soleira de porta numa dependência da quinta, onde se manteve até 1980, o monumento tem um aspecto algo medíocre, apesar de alisado, denunciando uma feitura local; muito gasto e com algumas mossas e falhas, perdeu por fractura a quase totalidade do topo, conservando, em contrapartida, uma espécie de pedúnculo para melhor fixação ao solo. O campo epigráfico, em que se destacam duas carteias levemente marcadas, parece ter ocupado cerca de metade da face principal da esteia, cujo campo inferior é decorado com um motivo templiforme de desenho muito esquemático, quase desaparecido devido ao desgaste provocado pela reutilização da pedra.

Dimensões: 128x58x10. Campo epigráfico: ?x58. Carteias: $1: ? \times 39,5 ; 2: 7 \times 39,5$.

\section{MASCELLI / MACRI}

(Sepultura) de Máscelo, (filho) de Macro.

Altura das letras: 1. 1: 6,5 (?); 1. 2: 6,5. Espaço entre as carteias: 17 .

b) Bibliografia e variantes

Belo, «Badaladas», 101, 1954 (desenho); Belo, Símbolos, p. 50 (desenho).

1. 1 : omitida por Belo. 


\section{c) Comentário}

Esta estela da Quinta da Portucheira, local de copiosos achados romanos, constitui um exemplo eloquente de como é necessário rever uma parte importante das inscrições publicadas, revisão que exige, naturalmente, a análise directa das epígrafes. Com efeito, as difíceis condições de observação oferecidas pelo monumento enquanto reaproveitado na quinta influenciaram negativamente a notícia que dele nos deixou Ricardo Belo; a omissão da 1. 1, então coberta por uma ombreira de porta, a indicação de dimensões menos correctas e a referência a um filete decorativo inexistente constituem os lapsos mais importantes. $O$ mesmo não sucede com a referência ao motivo considerado como «frontaria de casa, ou antes de templo», confirmada pelo investigador torriense Leonel Trindade e concordante com os vestígios remanescentes.

O lapidarius delimitou com cuidado as carteias, horizontais e bem centradas, nas quais inscreveu os cognomina. Todavia, a irregularidade do ductus prejudicou o equilíbrio procurado: na 1. 2, como o I ocupa pouco espaço, toda a verba parece deslizar para a esquerda; na 1. 1 terá sucedido o contrário. Os caracteres, próprios da escrita capital quadrada, foram gravados na vertical, em bisel, com notória imperícia: o $\mathrm{M}$ é muito aberto, deselegante, com o ângulo interior assente na linha; o $\mathrm{R}$ tem a haste oblíqua recta e ligada à pança num ponto afastado da haste vertical, forma que já encontrámos numa epígrafe de Torres Vedras (n. $\left.{ }^{\circ} 4\right)$; os travessões horizontais ocupam uma posição a meia altura do E e do A.

A 1. 1, apesar de prejudicada - pouco resta do $\mathrm{M}$ e do $\mathrm{A}$ iniciais - não implica problemas de leitura, permitindo reconhecer o genitivo MASCELLE

Os temas de inspiração arquitectónica, talvez de origem helenística $\left({ }^{23 \mathrm{G}}\right)$, são pouco vulgares em território português $\left({ }^{237}\right)$,

(236) J. Bonrdman, Greek Art, Londres, 1964, p. 149, fig. 138; J. M. Toynbee, A Arte dos Romanos, Lisboa, 1972, p. 95-96, 105.

$\left({ }^{237}\right)$ Sobre este assunto, e não obstante o seu interesse evidente, não existe qualquer estudo actualizado, pelo que nos limitamos a destacar alguns dos testemunhos mais interessantes: LEITE DE VASCONCELOS, Reli- 
apesar de frequentes, sob várias formas, na arte funerária hispano-romana ${ }^{(238)}$. Embora a sua interpretação suscite dúvidas, é possivel que, como pretende Cid Priego $\left({ }^{239}\right)$, a representação de edifícios templiformes em lápidas funerárias constitua uma deliberada e compreensível alusão, que parece nítida no caso das aras e dos sarcófagos $\left({ }^{24}\right)$, ao importante monumento que era o mausoléu (241). Uma atitude psicológica semelhante explicará a ocorrência de representações do mesmo tipo, mas agora comprometidas no reforço do carácter sagrado dos compromissos assumidos pelos contratantes, numa ou noutra tessera hospitalis, como a de Munigua (ILER 5831). O pouco que sobreviveu ao desgaste da pedra não permite, infelizmente, uma interpretação segura do tipo de edifício cuja fachada, composta de estilóbato, quatro colunas, arquitrave e frontão triangular, se representou na esteia da Portucheira.

Relacionado com o sexo masculino e nitidamente pertencente a um estrato onomástico popular, Mascellius é um cognome extremamente raro $\left({ }^{242}\right)$, aqui registado pela primeira vez na Península, onde apenas se conhecem formas aparentadas (243), entre as quais Mascellio $\left({ }^{244}\right)$, cognome presente em inscrições de Itálica (CIL II 1110), Castro el Rio (CIL II 1578), Córdova (CIL II 2293), Astorga (CIL II 2639), Tarragona (CIL II 4299), Segisama (CIL II 5812) e, na região torriense, numa epígrafe da ermida da Serra de S. Julião $\left({ }^{245}\right)$. A maior parte dos testemunhos referidos situa-se num ambiente social modesto no qual avulta o séviro tarraconense Marcus Herennius Mascellio (CIL II 4299),

giões, III, 1913, p. 389, 390, fig. 169, p. 414, fig. 185, p. 423, fig. 205; E. Borges Garcia, Um templo visigótico em S. Gião (Famalicão da Nazaré), «Arqueologia e História», XII, 1966, p. 208, fot. 22-23.

(238) Garcia y Bellido, Esculturas, p. 286-287, 301, 334-336; Aвásolo/ /ALBertos/Elorza, p. 74-78.

(239) C. Cid Priego, La Torre del Breny sepulcro romano en las cercanias de Manresa, «Ampurias», XII, 1950, p. 46.

(240) Abásolo/Albertos/Elorza, p. 83, 86; Toynbee, p. 104.

(241) Toynbee, p. 91-94, fot. 55; Alarcao, Portugal, p. 187.

(242) Lexicon, VI, 1940, p. 224.

(243) CIL, II, p. 1086; ILER, p. 718.

(244) KaJanto, Cognomina, p. 307.

(245) BEL o, «Badaladas», 51, 1952. 
seguramente um liberto. Quanto ao cognome Macer, muito raro entre libertos e escravos e que Kajanto considera relacionado com defeitos físicos $\left({ }^{246}\right)$, tem razoável representação na Hispânia, onde, além da Quinta da Portucheira foi referenciado em: Valença do Minho (CIL II 2465), Aramenha (CIL II 159), Nisa(247), Cuba (CIL II 5187), Caparra (CIL II 834, 835; CPIL 818), Montoro (CIL II 2166, 2172), Cabra (CIL III 1625), Osuna (CIL II 1407), Granada (CIL II 5511), Antequera (CIL II 2042), Córdova (CIL II 2238), Adra (CIL II 1992), Tarragona (CIL II 4120) e na região de Valência (CIL II $\left.4970{ }^{289}\right)$. $\mathrm{Na}$ área olisiponense a variante Macrinus está documentada em epígrafes de S. Miguel de Odrinhas (CIL II 303) e de Lisboa (CIL II 174). Os testemunhos conhecidos, em grande paite provenientes do Sudoeste, integram um grupo de estatuto social elevado, ao qual não são estranhas, aliás, ligações com a elite indígena romanizada. Algumas das sete inscrições lusitanas são muito elucidativas a este respeito: Publius Cornelius Macer, questor e duúnviro de Ammaia (Aramenha), recebeu a cidadania do imperador Cláudio (CIL II 159); M. Fidius Macer, devoto de Trebaruna, foi, antes de ascender à ordem equestre, magister e duúnviro de Cáparra (CIL II 834, 835; CPIL 818), onde construiu o grande tetrapylon $\left\{{ }^{248}\right)$; Publius Carminius Macer, assinalado numa ara proveniente de um possível santuário indígena dos arredores de Nisa, poderá estar relacionado com L. Calventius Vetus Carminius, governador da Lusitânia em 44/45 (249). As personagens mais importantes que testemunham o cognome Macer na Hispânia são, todavia, o governador da província lusitana entre 194 e 197, C. Caesonius Macer Rufinianiis $\left({ }^{2}{ }^{\circ}\right)$ e o procônsul da província de Creta e Cirene, Q. Gargilius Macer Acidinus, conhecido por uma epígrafe de Tarragona (CIL II 4120).

Que relação poderemos estabelecer entre Mascellius e Macer?

No caso presente parece possível, uma vez mais, subentender uma

(246) Kajanto, Cognomina, p. 244.

(247) ENCARNAÇão, Nordeste, p. 65-66, n..$^{\circ} 3$.

(248) A. Garcia y Bellido, El tetrapylon de Capera (Cáparra, Cáceres), «Archivo Español de Arqueologia», XLV-XLVII, 125-130, 1972-1974, p. 45-90.

(249) EnCarnaÇã o, Nordeste, p. 65-66, n. ${ }^{\circ} 3$.

(250) Alarcão, Portugal, p. 209.

Conimbriga, 21 (1982), 5-99 
filiação de tipo indígena, expressa apenas pelo genitivo, como pensamos suceder nas inscrições de Santa Maria do Castelo (n. ${ }^{\circ}$ ) e da Louriceira (.$^{\circ} 11$ ), embora a qualidade dos cognomina, sugerindo ambientes sociais diferentes, permita considerar Mascellius escravo ou liberto de Macer, hipótese pela qual preferimos não optar.

d) Datação

A extrema simplicidade do texto, a terminação em $i$ do genitivo de Mascellius (2Õ1), as características da escrita, permitem atribuir este monumento, tal como o anterior, à primeira metade do século $i$.

\section{1- LOURICEIRA. Foto 12}

\section{a) Descrição}

Esteia funerária de calcário, de grandes dimensões, encontrada em 1857 numa terra próxima da povoação de Louriceira, freguesia de S. Pedro, Torres Vedras. Inicialmente considerada como marco fundiário, a esteia aparenta a forma de uma espátula, de feitura e aspecto rudes, com o topo semicircular e a face posterior grosseira mente desbastada. A pedra encontra-se alterada por reacções químicas, as quais quase provocaram a destruição da inscrição, cuja leitura é, presentemente, muito difícil; acusa ainda algumas falhas e erosão generalizada dos contornos, deficiências em parte devidas à sua reutilização como soleira de porta. O campo superior da esteia, limitado por um rebordo boleado, comporta um ornato grosseiro em forma de arco, separado do rebordo por uma espécie de escocia, do qual se destaca, mediante uma depressão vigorosamente escavada, um crescente lunar invertido, de secção semicircular. O campo central do monumento integra 251

(251) p Monteil, Elements de Phonétique et de Morphologie du Latin, Paris, 1970, p. 162. 
três registos: o registo superior, a que corresponde aparentemente o campo epigráfico, é ocupado por uma cartela rectangular em rebaixo contendo a inscrição; os registos médio e inferior são preenchidos, respectivamente, por um rectángulo escavado e por dois quadriláteros paralelos, também escavados, um e outros toscamente delineados e despidos de quaisquer elementos decorativos. Os lados do termo inferior da esteia, destinado a fixá-la ao solo, estreitam progressivamente terminando numa ponta arredondada.

Dimensões: 155x40x22. Campo epigráfico: $8 \times 33$.

\section{RVFI BOVII}

(Sepultura) de Rufo, (filho) de Bóvio.

Altura das letras: 6,5.

\section{b) Bibliografia e variantes}

Torres, p. 20; Belo, «Badaladas», 98, 1954 (desenho); Belo, Símbolos, p. 43, 50, 56 (desenho).

\section{c) Comentário}

Dada a simplicidade da epígrafe e o seu péssimo estado de conservação, a análise paleogràfica fornece poucos elementos aproveitáveis. O lapidarius limitou-se a inscrever o texto de forma a ocupar o registo superior da esteia, sem recorrer aos restantes. Os caracteres, verticalmente alongados e perfeitamente aprumados, foram gravados com profundidade. Ricardo Belo referiu o tipo de letra desta inscrição como «a da boa época», afirmação hoje muito difícil de verificar a partir do que a pedra nos oferece. Ainda assim podemos: deduzir para o $\mathrm{R}$ uma haste oblíqua recta e para o $\mathrm{O}$ um desenho circular bastante razoável; reconhecer o traçado clássico do $\mathrm{B}$; notar a forma ligeiramente arredondada do V. O que resta sugere uma forma rústica da escrita capital quadrada. Não há vestígios de pontuação. Os editores de Madeira 
Torres não propuseram qualquer leitura ou tradução da epígrafe, correctamente transcrita. Ricardo Belo, nos trabalhos citados, traduziu, respectivamente, «Rufo, filho de Bóvio» e «Rufus, escravo de Bovius», sem explicar a razão desta última versão, aliás possível (252). Ainda que a filiação não se encontre directamente expressa, facto normal entre os adtributi superficialmente romanizados (253), preferimos a primeira das traduções. $\mathrm{Na}$ área que mais directamente interessa ao nosso estudo apenas uma epígrafe da Praia de Santa Cruz refere um escravo: D.M/ Pultari / / Flaviani i ser . ann . XXV / Voluptas / mater . f . c (CIL II 314). O sistema do nome único persistiu na Hispânia para além da concessão do Latium minus por Vespasiano (254); no presente caso refere certamente um peregrino. A análise cuidada das duas últimas letras da inscrição, bem conservadas, impede a leitura do antropònimo de que fazem parte como Bouti; a leitura correcta, embora menos habitual, é $B O V I I$.

Rufus é um cognome latino (255), usado de acordo com os testemunhos conhecidos, por indivíduos de origem livre entre os quais setenta e cinco senadores (256); deriva do adjectivo rufus, a, um - ruivo, avermelhado - e é muito frequente na epigrafia hispano-romana $\left({ }^{20 ̃ 7}\right)$, especialmente em zonas de predominância céltica, como a actual província espanhola de Cáceres (20̃8). Na região de Torres Vedras voltamos a encontrá-lo numa inscrição da ermida da Serra de S. Julião, onde é referido um Rufus executor testamentàrio $\mathrm{e}$ da qual nos ocupamos de novo adiante (n. ${ }^{\circ} 12$ ). De áreas limítrofes temos testemunhos provenientes de Colares (CIL II 320), Montelavar (259), Almoster (CIL II 310) e Lisboa

(252) Julio Mangas Manjares, Esclavos y libertos en la Espana Romana, Salamanca, 1971, p. 29.

(20̃3) ILER, p. 255.

(254) Alföldy, Notes, p. 51. Por outro lado, é preciso ter em conta que a aplicação do novo estatuto se verificou gradualmente, prolongando-se quase até ao final do século i: A La RCão, Portugal, p. 55.

(255) Schulze, p. 264, 295.

(256) KaJanto, Cognomina, p. 229.

(257) ILER, p. 741-742.

(258) CPIL, p. 370.

(259) Fontes, p. 35, n. ${ }^{\circ}$ CXXXV, p. 41. 
(CIL II 214, 225, 227, 4996, 5227); uma das epígrafes da capital alude ao edil designado C. Iulius Rufinus (CIL II 225). A norte do termo tómense o cognome Rufus tem, com as suas variantes normais, assinalável representação em Collipo (260) e em Conimbriga (261), cidade onde no último quartel do século i o cidadão C. Turranius Rufus surge como expoente conhecido de uma das mais importantes famílias locais (262). Recordaremos, ainda, uma personalidade provincial : C. Caesonius Macer Ruñnianus, governador da Lusitânia pelo final do século n (263). O gentilicio Rovius, a que já nos referimos largamente neste artigo, a propósito da inscrição torriense de Santa Maria do Castelo (n. ${ }^{\circ}$ 6), surge aqui utilizado como nome único. Dado que tal facto se verifica exclusivamente em ambientes célticos, inclusive em Egitânia, onde ocorre associado ao cognome Amoena numa esteia decorada com um crescente lunar (264), estaremos, como supõe M. L. Albertos (265), perante a latinização de um antropònimo indígena semelhante ?

A rude esteia da Louriceira enquadra-se num grupo de monumentos com particular representação no Noroeste peninsular, com alguns dos quais possui elucidativa semelhança (266). Apesar das ambiguidades propostas pela decoração astral, já suficientemente referidas $\left(n .^{\circ} 9\right)$, parece-nos necessário analisar rapidamente o tema do crescente lunar, um dos elementos mais frequentes da iconografia funerária hispânica $\left({ }^{267}\right)$, discutivelmente interpretado como símbolo da «morada dos mortos» $\left({ }^{268}\right)$, da «protecção sobrenatural» $\left({ }^{269}\right)$, da «esperança no além» $(270)$ ou, ainda, do culto de

$\left(26^{\circ}\right)$ Pinho Brandão, p. 142.

(261) Fouilles, p. 227.

(262) Fouilles, p. 91-93, n. ${ }^{\circ}$ 70, pi. XIV, p. 99.

(263) Alarcão, Portugal, p. 209.

(264) Almeida, Egitânia, p. 167, n. ${ }^{\circ}$ 40, fig. 123.

(265) Albertos, Antropónimos, XXXII, 2, 1964, p. 231.

(266) Juliá, Vigo, p. 12-13, pi. 6a; F. Manuel Alves, Guia epigráfico do Museu do Abade de Baçal, Bragança, 1975 (reedição), p. 85, n. ${ }^{\circ} 48$.

(267) Garcia y Bellido, Esculturas, p. 331-334.

(268) CUMONT, p. 117.

(269) A. D. Nocк, Sarcophagi and Symbolism, «American Journal of Archaeology», L, 1942, p. 142.

$\left(27^{\circ}\right)$ M. Leglay, Saturne Africain, Paris, 1966, p. 173.

Conimbriga, 21 (1982), 5-99 
Diana (271). Na região de Lisboa, numeroso material arqueológico da Cultura do Tejo sugere a existência de um importante culto lunar pelo menos a partir da primeira metade do III milénio a. C. (272). Alguns acidentes do terreno surgem nas fontes antigas directamente relacionados com o culto lunar: a Serra de Sintra e o Cabo da Roca denominavam-se respectivamente, segundo Ptolomeu, Mons Lunae e Promontorium Lunae (273); nessa zona foram registadas algumas inscrições votivas romanas ao Sol e à Lua(274), consagração que se repete noutros locais da Hispânia em relação ao último dos astros (ILER 345, 347, 639, 640, 641); Avieno refere como igualmente consagrada à Lua uma ilhota ao largo de Málaga (275). O santuário da Lux Divina perto de Sanlúcar de Barrameda, na foz do Guadalquivir, estaria de igual modo relacionado com uma divindade lunar (276). Estrabão, numa passagem preciosa, refere os Calaicos como ateus e cita a propósito as danças executadas pelos Celtiberos e seus vizinhos nortenhos, nas noites de plenilúnio e em frente das casas, em honra de uma divindade inominada $\left({ }^{277}\right)$, divindade que não era outra, certamente, senão a Lua, da qual como sucedia entre outros povos, não era permitido pronunciar o nome $\left({ }^{278}\right)$.

O que fica exposto é suficiente para provar a importância e antiguidade do culto lunar na Península, sem que, todavia, seja possível avaliar a influência sobre ele exercida na época romana por fenómenos de interpretatio, que poderão ter assimilado o culto indígena aos cultos de Diana ou da Dea Caelestis, versão romanizada da deusa púnica Tanit $(279)$, de quem o crescente invertido era um

(271) Abásolo/Albertos/Elorza, p. 73-74; ILER, p. 43.

(272) H. Sa vory, Espanha e Portugal, Lisboa, 1969, p. 126-140.

(2:3) Ртоцомeu, II, 5, 3.

(274) As inscrições CIL II 258 e 259; muito provavelmente também a de C. Iulius Celsus: S. Lambrino, Les inscriptions de São Miguel de Odrinhas, «Bulletin des Études Portugaises», XYI, 1952, p. 142-150, n. ${ }^{\circ} 24$ ( = LaM B RINo, Odrinhas).

(275) Avieno, 367-368, 428-431.

(276) Blázquez, Estudios, p. 462.

(277) Estrá̃ $\mathbf{O}$, III, 4, 16.

(278) Blázquez, Estudios, p. 451-452. Na região de Torres Vedras é vulgar a Lua ser designada como Madrinha do Céu.

(279) D. Harden, OS Fenícios, Lisboa, 1968, p. 85-87. 


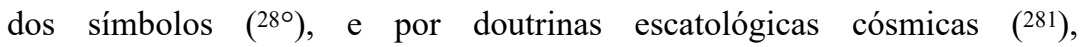
Urna vez que a Hispânia é a região do Império Romano onde o culto de Caelestis melhor documentado se encontra depois de Roma e da África do Norte (282) parece razoável atribuir ao crescente invertido uma origem africana, hipótese sugerida pela relativa raridade dos testemunhos e sua distribuição geográfica, essencialmente litoral, assim como pelo registo de outros símbolos de irrecusável natureza púnica, nomeadamente em Vigo (283) e em Barcelona (284). Ao influxo cultural pùnico (285), sobre o qual se torna urgente um estudo profundo visando o território português, se deverá, ainda que parcialmente, a fraca representação dos cultos célticos a sul do Tejo (286). Resta referir as tão numerosas quão nebulosas sobrevivências do culto lunar, ou de outros com ele relacionados, nas tradições populares hispânicas e norte-africanas (287), entre as quais destacaremos a execução de danças em honra da Lua, danças que persistiram na Galiza até ao princípio deste século $\left({ }^{288}\right)$.

O belo jarro púnico-tartéssico encontrado em Torres Vedras, conservado no Museu (289), constitui um prometedor indício do tipo

$\left({ }^{28}\right)$ Jyp Hours-Miédan, Les représentations figurées sur les stèles de Carthage, «Cahiers de Byrsa», I, 1950, p. 36; H A R DE N, p. 96-97, fig. 24-25.

(281) Grant, p. 191-195; Petit, p. 202-205.

(282) A. Garcia y Bellido, El culto a Dea Caelestis en la Península Ibérica, «Boletín de la Real Academia de la Historia», CXL, 1957, p. 468-485.

(283) JuliA, Vigo, p. 29-30.

(284) I. RODÂ DE MAYER, La dispersion del poblamiento en el término de Barcelona en la época anterromana, «Cuadernos de Arqueologia e Historia de la Ciudad», XVII, 1977, p. 80-82, fig. 10. Comparar com: HARDEN, p. 271 , fot. 35 .

(285) J. M. Blâzquez, Economia de la Hispania Romana, Bilbau, 1978, p. 619-646 (BLÂZQUEZ, Economia).

(286) Alarcão, Portugal, p. 168; Jorge de Alarcão, Sobre a economia rural do Alentejo na época romana, «Conimbriga», XV, 1976, p. 8-9.

(287) Gautier, p. 146-148.

(288) BLÂZQUEZ, Estudios, p. 453.

(289) Leonel Trindade/Veiga Ferreira, Acerca do vaso «piriforme» tartéssico de bronze do Museu de Torres Vedras, «Boletim Cultural da Junta Distrital de Lisboa», 63-64, 1965, p. 175-183; A. GarCia Y Bellido, Algunas novedades sobre la arqueologia punico-tartessia, «Archivo Español de Arqueología», XLIII, 1970, 121-122, p. 28-31.

Conimbriga, 21 (1982), 5-99 
de relações que poderão ter introduzido na região elementos culturais como o crescente invertido.

\section{d) Datação}

Atendendo ao aspecto geral, à ausência de fórmulas e à denominação em genitivo, atribuímos este monumento à segunda metade do século i.

\section{2 -SERRA DE S. JULIÃO. Foto 13}

Tampa de arca cinerària de calcário lioz proveniente de uma parede do pátio da Quinta da Rainha, para onde fora levada da ermida da Serra de S. Julião, freguesia da Carvoeira, Torres Vedras, onde se encontrava aproveitada como pedra de altar. $\mathrm{O}$ monumento, regularmente conservado, sofreu a perda da primeira linha da epígrafe, o que poderá ter sucedido quando foi colocado na parede da quinta; as cinco linhas restantes acusam razoável desgaste e algumas mossas. A inscrição era enquadrada por uma moldura, picada para aplanar a superfície da pedra por altura da reutilização no altar da ermida, virtualmente patente nos bordos laterais e inferior, cuja aspereza contrasta com o cuidadoso acabamento do campo epigráfico. $O$ dorso foi apenas afeiçoado a picão e possui um rebordo para assentar sobre a arca cinerària $\left({ }^{290}\right)$. O monumento encontra-se depositado no Museu por especial deferência dos herdeiros de D. Segismundo de Alarcão.

Dimensões: 174x61x17. Campo epigráfico: 146x53(?).

[DIS . MANIBVS] / Q (uinti) . CAECILI . (Quinti) . F (ilii) . GAL \{erta tribu) CAECILIANI . AEDILIS/AN (norum) . XXXX . / M (arci) . CAECILI . Q (uinti) . F (ilii) . GAL(ma tribu) . AVITI / minorum) . XVIII / IVLIA . M (arci) . F (ilia) . MARCELLA . MARITO . OPTVMO / 5 FILIO . PIISSIMO . DE . SVO . FECIT

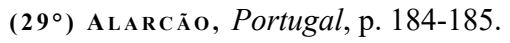


Aos deuses Manes de Quinto Cecilio Ceciliano, filho de Quinto, da tribo Galéria, edil, de quarenta anos de idade, e de Marco Cecilio Avito, filho de Quinto, da tribo Galéria, de dezoito anos de idade. Julia Marcela, filha de Marco, ao seu excelente marido e filho tão piedoso mandou fazer à sua custa (este monumento).

Altura das letras: 1. 1: 6; 1. 2: 6; 1. 3: 6; 1. 4: 6; 1. 5: 7 . Espaços: $1: 1,5 ; 2: 1,8 ; 3: 1,8 ; 4: 1,5 ; 5: 6$.

\section{b) Bibliografia e variantes}

Azevedo, 3, p. 82; Torres, p. 18; Pinho Leal, IX, 1880, p. 663-664; CIL II 261; Belo, «Badaladas», 48, 49, 50, 51, 1952; ILER 5550.

1. 1: não foi transcrita por TORRES e PINHO LEAL.

1. 2: Q . GAI . C . III . Q . I . GAL . CAL . C. III . (AZEvedo), Q . CAE . C . Ill . Q . I . GAI . CA . C . Ill . AN . I (PINHO LeAL).

1. 2/3: translineação correcta apenas em TORRES, PINHO LEAL e BELO).

1.3: AN . I . (AZEVEDo), IXXXX (Torres, Pinho LeAL).

1. 4: M . GAI . OHI . OI . GAL . AVIII (AzEvedo), I . GAI . AVIII(TORRES), M . CAICILI . Q . I. CAI (PINHO LEAL).

1. 5: E . MARCILLA MARIIO (AZEVEDo), I . MARCILIA . MARIIO . O . PIMO (TORRES), E . MARCILIA . MARIIO . OPTIMO (PINHO LEAL).

1. 6: OPIVMO . IIII . 0 (AzEVEDo).

\section{c) Comentário}

As transcrições de Marinho de Azevedo, Madeira Torres e Pinho Leal estão longe de concordarem, quer entre si, quer com o texto real. Os dois últimos autores duplicaram a inscrição iludidos pela transferência do monumento da ermida de S. Julião para a Quinta da Rainha, deslocação efectuada numa data indeterminada entre 1633 e 1861, pelo que referimos apenas as variantes verificadas nas transcrições feitas a partir da observação directa da epígrafe, eliminando as que se filiam no texto de Azevedo. 
A inscrição foi cuidadosamente concebida, apresentando um texto equilibrado e esteticamente agradável, apesar da franca deslocação das 1. 4 e 5 no sentido da esquerda e do glande espaço que, na 1. 3, medeia entre a sigla e o numeral; tal espaço contribui, aliás, para o equilíbrio do conjunto. Todo o texto foi disposto em torno de um eixo de simetria; a regularidade da escrita garante a utilização de linhas auxiliares. Pontuação de sinais circulares, muito apagada, austera e correcta, embora nem sempre necessária, como na 1. 6. O desenvolvimento da inscrição é clássico: a primeira linha foi reservada para a consagração, abreviada, aos deuses Manes; a segunda, terceira e quarta linhas contêm a identificação do marido e do filho da dedicante, com indicação das idades e do cargo desempenhado pelo primeiro: as duas últimas linhas informam-nos sobre os laços familiares e sobre as circunstâncias da construção do monumento funerário. A gravação é profunda, de incisão triangular. Escrita de tipo capital quadrada, vertical, denotando um ductus nem sempre perfeito e com certa tendência para adernar sobre a esquerda. $\mathrm{O}$ espaço disponível dispensou o recurso a nexos e a letras reduzidas. A análise dos caracteres, limitados por pequeníssimos ápices, destaca o seguinte: o desenho do $\mathrm{O}$ é ligeiramente elíptico e a partir dele foram obtidos $\mathrm{o} \quad \mathrm{C}$ e $\mathrm{o} \quad \mathrm{Q}$, este com uma haste inclinada e recta relativamente longa; o $G$ pertence a um tipo rústico, frequente no século i, como já vimos (n. $\left.{ }^{\circ} 4\right)$, e muito Amigar no século ii(291); $\mathrm{M}$ muito aberto, com as hastes externas inclinadas e o ângulo interior sobre a linha; o $\mathrm{S}$ acusa certa influência actuária; $\mathrm{P}$ aberto, regular, a partir do qual se desenhou o R; os E, F, T e L têm os travessões curtíssimos, dificilmente AÚsíveis, característica frequente no século $\mathrm{II}\left({ }^{292}\right)$; o traçado do A e do $\mathrm{V}$ corresponde a um triângulo isósceles; o $\mathrm{X}$ tem desenho normal, com as hastes formando as diagonais de um rectángulo; o D é típico do século n.

A onomástica presente na inscrição é perfeitamente latina, tendo parte dela grande representação na Península. Acerca do

(291) Ratlle HCgue T, p. 12-13, 227, lám. VII, 1; Cagnat, p. 501, pi. X, 3 .

(292) CagaAt, p. 18.

Conimbriga, 21 (1982), 5-99 
gentilicio Caecilius já tecemos algumas considerações neste artigo, a propósito de L. Caecilius Gaetulicus (n. ${ }^{\circ}$ 2). Todavia, referiremos a existência, em Sagunto, de um edil e pontífice $Q$. Caecilius pertencente à tribo Galéria (CIL II 3857) e recordaremos o já citado edil designado olisiponense C. Caecilius Gallus (CIL II 192), magistrado que J. F. Martin relaciona com os Caecilii da presente inscrição (293); o cognome Gallus encontra-se sobretudo nas regiões mais romanizadas (294). Uma inscrição funerária recolhida no Redondo, perto de Évora, alude a um L. Caecilius Gallus, tio de um M. Fulvius Caecilianus (CIL II 193), indivíduos muito provavelmente aparentados com os Caecilii edis. O cognome Caecilianus parece ter sido frequente entre pessoas de posição social elevada (295). O sufixo ilianus, versão divulgada de Miamis, derivará de formas em iUusJUla $\left({ }^{2 W}\right) \mid$ no caso de Caecilianus trata-se, sem dúvida, de uma terminação em anus formada sobre o gentilicio paterno (297), sob a forma mais tardia e vulgar ianus (298). Dos cem exemplos deste cognome registados no CIL cinquenta e sete pertencem ao volume Vili. É pouco habitual na Península, onde por volta de 320 foi usado por um governador da Lusitânia ${ }^{299}$ ), tendo sido assinalado em Mérida (ILER 3668), Cabra (Córdova, CIL II 1620), Redondo (CIL II 5193), Alcalá de Henares, onde ocorre um Caecilius Caecilianus (CIL II 3039), e Tarragona (CIL II 4153, 4199) onde a segunda das inscrições recorda $\mathrm{o}$ duùmviro $\mathrm{e}$ flàmine provincial $L$. Caecilius Caecilianus, personagem inserita, porém, na tribo Quirina; em Ibiza foi referenciado um Cecilianiis (ILER 3411). O Itinerário de Antonino refere uma povoação Caeciliana, situada entre Caetobriga (Setúbal) e Malececa (Marateca?), topónimo derivado regular-

(293) Martin, p. 238-239.

(294) UNTERMANN, p. 111-112, mapa 41.

(290) Kajanto, Cognomina, p. 35, 142.

(296) Kajanto, Cognomina, p. 13-14.

(297) THYLANDER, p. 113-114.

(298) Schulze, p. 17; H. Solin, Die innere Chronologie der Römischen Cognomens, «Actes du Colloque International sur l'Onomastique Latine», Paris, 1977, p. 138-139.

(299) Alailcão, Portugal, p. 209.

Conimbriga, 21 (1982), 5-99 
mente do gentilicio de Q. Cecilio Metelo Pio $\left({ }^{300}\right)$. Na Mauritàma Tingitana, região com a qual o Sudoeste hispânico manteve intensas relações, inclusive de ordem política ( $\left.{ }^{301}\right)$, a cidade de Volubilis teve como patrono o legado imperial Sextus Sentius Caecilianus (302). Atendendo à transmissão regular dos nomes familiares romanos é possível que $Q$. Caecilius Caecilianus ocupasse o segundo lugar na ordem de nascimento ${ }^{(303)}$. O cognome Avitus é muito frequente na Península, em especial na Hispania Citerior e na região de Sagunto (304). M. L. Albertos destaca a sua grande difusão em zonas célticas, onde poderá recobrir um nome indigena (305). Referenciado em todas as camadas sociais, mas pouco frequente entre os libertos, ilustra laços de parentesco - avitus [a/um: que vem dos avós - e derivará de um substracto itálico pré-latino ( $\left.{ }^{306}\right)$; foi muito utilizado, entre outros, pelas gentes Flávia e Júlia ${ }^{(307)}$. Presente no aro tómense nesta inscrição e, também sob a forma feminina, na que se conserva na igreja de Matacães (CIL II 278), o cognome Avitus atinge notável concentração nos municípios de Olisipo (308), Collipo $\left.{ }^{309}\right)$ e Conimbriga $\left({ }^{\left(31^{\circ}\right.}\right)$. Em Olisipo duas importantes inscrições comemorando Adriano e Sabina aludem ao duúnviro L. Iulius Avitus (CIL II 186, 4992); Caecilia Avita é o nome da dedicante, em Conimbriga, de urna àrnia a Apolo Augusto (ILER 169), acto religioso e politico que nos conduz ao ambiente específico das elites municipais, bem reflectido na epígrafe da Serra de S. Julião. Em Norba, a moderna Cáceres, foi assinalado um Q. Caecilius Avitus (CIL II 700). lidia Marcella usou um cognome do qual se conhecem cinquenta

${ }^{300}$ Alarcão, Portugal, p. 68, 70; Schulze, p. 453-455; C. Bémont, Liciniana Officina, «Latomus», XXVII, 3, 1968, p. 610-616.

(301) BlázQuez, Economia, p. 652.

(302) Gascou, p. 115.

(303) Cagnat, p. 68-69.

(304) UNTERMANN, p. 65-66, mapa 14.

(30ó) Kajanto, Cognomina, p. 18, 80; Albertos, Antropónirnos, XXXII,

2, 1964, p. 227.

$\left(3^{\circ} 6\right)$ Al в e r tos, Onomástica, p. 45.

(307) Lexicon, V, 1940, p. 231-232.

jsosj Víeíra da Silva, p. 276-283, n. ${ }^{\circ}$ 72, 91, 102, 106, 115, 121, 131.

${ }^{(309)}$ Pin ho Brandẽ o, p. 141, n. ${ }^{\circ} \mathrm{XIV}, \mathrm{XX}$, XXX, XXXI.

$\left(31^{\circ}\right)$ Fouilles, p. 226. 
e dois exemplos peninsulares, vinte e nove deles femininos ( $\left.{ }^{3 \mathrm{U}}\right)$. $\mathrm{O}$ nome completo repete se, ainda, em inscrições de Palência (CIL II 2717), Lamego (CIL II 5251), Terena, esta dedicada a Endovélico (CIL II 5204), Sines (ILER 3201) e numa outra proveniente de um local indeterminado da Lusitânia Ocidental (CIL II 77); em Santiago do Cacém uma inscrição perdida - mas que nos parece insuspeita - refere o caudicário M. Iulius Marcellus, edil e duúnviro mirobrigense (CIL II 25); em Toledo registou-se uma Caecilia Marcella (CIL II 3075). Terminaremos esta longa enumeração, da qual naturalmente não podemos extrair relações familiares concretas mas que comprova o estatuto social elevado de uma parte importante dos testemunhos, referindo o duúnviro olisiponense L. Iulius Avitus, o qual desempenhou o cargo em 121/122 (CIL II 186).

As dimensões e qualidade do monumento estão de acordo com uma família pertencente à ordo decurionum; abstraindo da hipótese céltica do cognome Avita, nada obsta a que lhe atribuamos uma possível origem itálica, sem esquecer, todavia, a simbiose entre elementos indígenas e itálicos, ampiamente melificada por toda a parte e nitidamente confirmada na região torriana. A edilidade era uma magistratura municipal própria das cidades de constituição romana, muito rara nas regiões célticas e germânicas (312). As leis Ursonensis (CIL II 5459), Malacitana (CIL II 1963) e Salpensana (CIL II 1964) permitem uma visão correcta das instituições municipais na Hispânia (313), onde as cidades peregrinas constituiram a esmagadora maioria até à reforma administrativa flaviana $\left({ }^{314}\right)$. Os magistrados eram normalmente quatro: os duoviri e os aediles, formando o colégio anual dos quattuorviri; estes podiam ascender à ordem equestre por adlectio, através do cursus municipal (CIL II 49; ILER 1394). No sector português da Lusitânia foram referenciados mais sete edis: cinco em Lisboa

(311) ILER, p. 716 .

(312) E. DE Ruggiero, Dizionario Epigrafico di Antichità Romane, I, Roma, $1961^{2}$, p. 266-268.

(313) Alvaro D'Ors, Epigrafia Jurídica de la España Romana, Madrid, 1954, p. 135-346.

(314) BlázQuez, Economia, p. 14-15. 
(CIL II 192, 193, 194, 225, 262), um em Mirobriga (Santiago do Gacém, CIL II 25) e um em Beja (CIL II 50). A epígrafe da Serra de S. Julião não indica, infelizmente, qual o município em que Caecilianus exerceu o cargo. No Sudoeste do conventus escalabitano conhecemos várias cidades além de Scallabis e de disipo: Ierabriga (arredores de Alenquer), EburobriUium (Amoreira de Óbidos) e Trutobriga (?) (arredores do Cadaval), as duas últimas municípios ílavianos. Sobre o estatuto de Ierabriga estamos mal informados (315), mas o facto das inscrições locais referirem apenas a tribo Galéria, aliado ao silêncio de Plínio, sugere uma possível integração no território de uma das cidades de estatuto romano mais próximas, disipo ou Scallabis. Por outro lado, não parece crível tratar-se de um edil de Eburobritium, município tardio, adstrito á tribo Quirina (316), cuja área não incluiria decerto uma zona tão nitidamente relacionada com a tribo Galéria como é a região de Torres Vedras; o mesmo argumento é válido em relação ao obscuro município de Trutobriga ( ${ }^{317}$ ). Assim, tendo em conta a permanente vocação olisiponense da região torriana, resultante das realidades geográficas e económicas e favorecida pelas vias de comunicação existentes, nomeadamente o troço local de uma estrada cujo percurso a descrição pliniana da faixa costeira entre o Mondego e o Tejo sugere ( ${ }^{318}$ ), preferimos incluir L. Caecilius Caecilianus no album dos magistrados municipais de disipo. Esta inclusão é francamente apoiada, aliás, não só pela expressão da cidadania como pela distribuição do gentilicio Caecilius e do cognome Avitus e pela invulgar representação olisiponense da magistratura edilitària. A atribuição proposta é ainda confirmada pelo significativo registo em Dois Portos, nos arredores de Torres Vedras,do epitáfio de Q. Coelius Aquila (CIL II 284), filho do duumviro olisiponense Q. Coelius Cassianus, um dos dois magistrados referidos na já citada inscrição lisboeta de 178/180 comemorando o imperador Cómodo (CIL II 187).

(315) Alarcĩo, Portugal, p. 75-76; A. Tovar, Iberische Landeskunde, 2, Baden-Baden, 1976, p. 265-266 ( = Tova R, Landeskunde).

(316) Alarcão, Portugal, p. 85; Tovar, Landeskunde, p. 263-264.

(317) Tova R, Landeskunde, p. 265.

(318) Plinio, N. H., IV, 21: Aeminium $\mid$ Conimbriga $\mid$ Collipo $\mid$ Eburobrittium $\mid$ IOlisipo. A esta via pertenceu um marco miliàrio, inédito, de Alfeizerão. 
As expressões MARITO OPTVMO e FILIO PIISSIMO são normais e encontram-se abundamente documentadas, o mesmo se verificando em relação à fórmula final. A troca do $\mathrm{I}$ por $\mathrm{V}$ no superlativo optiimo foi já referida neste artigo, numa fórmula semelhante (n. ${ }^{\circ}$ 6) e num cognome (n. $\left.{ }^{\circ} 7\right)$. Conservadorismo ou pronúncia $\left({ }^{319}\right)$ ?

Os vestígios íomanos são abundantes na freguesia da Carvoeira. $\mathrm{Na}$ parede do pátio da Quinta da Rainha $\left({ }^{32}\right)$, além da presente inscrição, havia uma outra, hoje desaparecida: Terentia / $C . f$. Stacte I h.s.e. sit. tibi / tera (sic) . levis (321). A ermida da Serra de S. Julião conservou numa parede, até há bem poucos anos, a seguinte epígrafe truncada: [...] ascellio $/[\ldots] / *$. Severo $/[\ldots]$ ins Rufus I [...]stamento / [...]c( $\left.{ }^{322}\right)$; anteriormente já fora destruído um sarcófago colocado na parede do adro, sarcófago cujas dimensões, aliás, náo coincidiam com as do monumento que analisamos (323). $\mathrm{Na}$ encosta de $\mathrm{S}$. Julião há restos antigos tradicionalmente atribuídos aos Mouros; entre os numerosos materiais ultimamente recuperados na área contam-se fragmentos de ânforas e tesselas de vidro, achados que confirmam a existência de uma importante estaçáo arqueológica, antes sugerida pelos monumentos epigráficos.

\section{d) Dataçào}

Quer a análise paleogràfica, quer os elementos postos em relevo pela crítica interna, nomeadamente a invocação aos deuses Manes, o uso do dativo, a indicaçáo das idades e a utilização de adjectivos para qualificar maritus e filius permitem considerar de meados do século n esta notável inscrição.

(319) NIEDERMANN, p. 24.

$\left(32^{\circ}\right)$ A Quinta da Rainha deve o nome a ter pertencido à infanta D. Teresa, filha de D. Sancho I, rainha de Leão, que a doou ao convento de Santa Maria de Celas, extramuros de Coimbra.

(321) BELO, «Badaladas», 50, 1952.

(322) BELO, «Badaladas», 51, 1952. A ermida foi objecto de obras em meados da década de setenta, em virtude das quais a inscrição ficou (?) oculta. As autoridades eclesiásticas, como responsáveis directas pela conservação de um imenso património semelhante, deveriam fiscalizar rigorosamente a realização deste tipo de obras para evitar depredações perfeitamente evitáveis e francamente condenáveis.

(323) BELO, «Badaladas», 51, 1952. 
13 -- QUINTA DO CARACOL. Foto 14

a) Descrição

Grande estela funerária rectangular, de calcário, encontrada alguns anos antes de 1873 na Quinta do Caracol, freguesia de Aldeia Gavinha, Alenquer. Razoavelmente bem conservada, apresenta na base uma fractura oblíqua que prejudicou o final das 1. 4 e 5 da inscrição; a erosão provocou alterações nos contornos e obliterou parcialmente a decoração, constituída por uma rosácea hexapétala inscrita num duplo círculo radiado, decoração que ocupa o sector superior da face principal da esteia, preenchida no restante espaço pelo campo epigráfico. O reverso foi irregularmente desbastado.

Dimensões: 155x63x9. Campo epigráfico: 98x63.

\section{$\mathrm{L}$ (ucius) . LICINIV/S . TEMPO/RANVS / A(nnorum) . XXXV . H(ic). S(itus). E(st) $l^{5} M A($ ter $) . \mathrm{S}(u a)$}

Lúcio Licinio Temporão, de trinta e cinco anos de idade, está aqui sepultado. Sua mãe (mandou fazer este monumento).

Altura das letras: 1. 1: 9; 1. 2: 9; 1. 3:9,5; 1. 4: 9,5; 1. 5: 9,5. Espaços: $1: 3 ; 2: 10 ; 3: 10 ; 4: 10 ; 5: 1 ; 6: 17$.

\section{b) Bibliografia e variantes}

Pinho Leal, I, 1873, p. 86; Hübner, Notícias, p. 18; CIL II 308; Belo, «Badaladas», 138, 1955 (desenho); Belo, Símbolos, p. 43, 52 (desenho); ILER 6171.

1. 1: HIRCYNIY (PINHO LEAL).

1. 4: H. S (BELO).

1. 5: D . M . (Pinho Leal), C (Hübner, CIL II, Belo). 


\section{c) Comentário}

Hübner, nas Noticias Archeologicas de Portugal (324), ao referir indirectamente a inscrição de Aldeia Gavinha, local onde terão aparecido outros vestígios luso-romanos, exprimiu uma opinião que não nos parece indiscutível, apesar da medíocre qualidade do monumento, vagamente atribuído por $\mathrm{J}$. Vives à região de Lisboa. A paginação é péssima, não obstante a tentativa de alinhamento a partir de um eixo longitudinal. A translineação cortou o nome e o cognome do defunto, no primeiro caso sem grande necessidade; as linhas descaem acentuadamente para a direita e a sua distribuição pelo campo epigráfico é muito irregular. A pontuação foi marcada correctamente: o primeiro dos sinais é cruciforme; os restantes oscilam entre as formas triangular e circular. Gravação muito profunda e de incisão triangular, indecisa. Os caracteres são do tipo monumental, degradado, com forte influência das escritas actuária e cursiva. A irregularidade é geral: a inclinação, o tamanho das letras, os espaços que as separam, o desenho dos ápices, tudo varia. 0 vértice do $\mathrm{Y}$ é arredondado; o $\mathrm{L}$ e o $\mathrm{T}$ têm os travessões estreitos; a pança do $\mathrm{R}$ está longe da forma clássica semicircular normal; o travessão do A, contudo, ocupa uma posição central, o mesmo sucedendo com o do $\mathrm{H}$; o $\mathrm{P}$ tem um desenho arcaico; o $\mathrm{O}$ é quase circular. $\mathrm{O}$ nexo MA nada tem de especial, salvo o seu ductus tortuoso.

O gentilicio Licinius, já assinalado na inscrição da Quinta da Macheia (n. ${ }^{\circ}$ ), é, como vimos, vulgar na região de Lisboa. À gens Licinia pertenceram alguns cónsules, entre os quais destacaremos P. Licinio Crasso, governador da Hispânia Ulterior na primeira década do século i a.C., e L. Licinio Sura, general de Trajano em honra de quem foi construído o arco honorífico de Bará, perto de Tarragona (CIL II 4282), individualidade com a qual podemos certamente relacionar muitos dos Licinii peninsulares (ILER 1339-1356). Em Cauche el Viejo, perto de Málaga, uma extensa inscrição enumera vários detentores do nome, alguns deles usando cognomina referenciados na área torriense (CIL II 2056); o mesmo sucede corn a epígrafe gaditana de L. Licinius

(324) HüBne R, Noticias, p. 18.

Conimbriga, 21 (1982), 5-99 
Rufus (ILER 2658). Na Lusitânia conhecemos um Q. Licinius Saturninus, cluúnviro de Metellinum (Medellin, CIL II 610). No concentus pacense o gentilicio ocorre, por exemplo, em Juromenha (ILER 3729) e Faro (325), usado por individuos com os tria nomina. A análise, ainda que parcial, das inscrições em que ocorre deixou-nos a impressão de ter sido vulgar entre um grupo social ligado ao iundo populacional indígena e contendo importante percentagem de libertos. Quanto ao cognome Temporanus, Kajanto relaciona-o com as circunstâncias de nascimento - nascido no bom momento, benvindo - como derivado em anus de tempus (326) ; o facto de ter sido referenciado, em toda a Romania, apenas nesta epígrafe, confere-lhe um interesse especial. Um cognome aparentado, Tempestivus, foi assinalado, na Hispânia, em Lérida (CIL II 3012), Puebla de Castro (CIL II 5840), Tarragona (CIL II 2478) e Tortosa (CIL II 4027). Formulário : a abreviatura de annorum reduzida ao $\mathrm{A}$, embora pouco frequente, é normal ( $\left.{ }^{327}\right)$. A fórmula final suscita um problema de interpretação, não de leitura, correctamente efectuada por Levy Jordão como MA. S, formula que interpretada corno MA(ww) . S(ua) nos indicaria um suicídio, hipótese apoiada por um único paralelo peninsular registado numa inscrição bética de Astigi (GIL II 1501); assim, preferimos interpretá-la como MA (ter) . S (ua). Tratando-se certamente de uma inscrição anterior ao século $\mathrm{m}$, cujo teor obedece às leis fundamentais da epigrafia funerária latina, a ocorrência dos tria nomina em conjugação com a falta de referências à tribo e à filiação do defunto favorecem a hipótese de se tratar de um liberto.

O elemento fundamental da decoração desta esteia, cujas circunstâncias da recuperação foram saborosamente descritas por Ricardo Belo no jornal torriense «Badaladas», consiste numa grande rosácea hexapétala inscrita num duplo círculo radiado. Normalmente interpretada como símbolo solar ${ }^{(328)}$, a rosácea é,

(320̈) M. Lyster Franco, Uma inscrição inédita de Ossonoba, "Gosta de Oiro», 64, 1940, p. 9-10.

(320̈) Kajanto, Cognomina, p. 108, 296.

(327) Cagnat, p. 408.

(328) Abásolo/Albertos/Elorza, p. 69.

Conimbriga, 21 (1982), 5-99 
com numerosas variantes, um dos temas decorativos mais vulgares da arte indígena peninsular, com especial projecção nas regiões do Centro e Noroeste ${ }^{(329)}$. No litoral túrdulo do conventus escalabitano é pouco frequente: ocorre na lápida funeraria de Annia Maxsuma, encontrada muito perto de Aldeia Gavinha, em Arruda dos Vinhos $\left({ }^{33^{\circ}}\right)$; ausente nos monumentos epigráficos olisiponenses e coliponenses, aflrma-se substancialmente em Conímbriga ( $\left.{ }^{331}\right)$. A ampla representação da rosácea na iconografia funerária do sector céltico ou celtizaclo da população hispânica levou numerosos investigadores a considerá-la como um produto típico do celtismo ( ${ }^{332}$ ), interpretação que nos parece francamente exagerada porquanto ignora ou minimiza o seu largo emprego em ambientes culturais e geográficos completamente diferentes. Dentro de uma perspectiva alargada recordaremos que a rosácea é um elemento decorativo habitual nos mosaicos do Alto Império ( $\left.{ }^{333}\right)$, nomeadamente nos mosaicos herodianos da Palestina (334), ocorrendo ainda, embora de forma degradada, como sobrevivência e não como inovação bárbara, em obras tardias, entre as quais destacaremos o célebre mosaico emeritense de Annius Ponius ( ${ }^{335}$ ). Outro exemplo significativo reside na extraordinária importância que a referida temática assume na decoração funerária hebraica do século i (336). Assim, parece-nos extremamente difícil atribuir

(329) Juliá, Vigo, p. 26.

$\left(3^{\circ}\right)$ J. Leite de Vasconcelos, Lápides lusitano-romanas de Arruda dos Vinhos, «Homenagem a Martins Sarmento», Guimarães, 1933, p. 191-192.

(331) Fouilles, p. 211-212.

(332) R. Bianchi Bandinelli, Roma. La fine delVArte Antica, Milão, $1976^{2}$, p. $184,192$.

(333) A. Blanco Freijeiro, Mosaicos romanos de Italica (Corpus de Mosaicos Romanos de España, II), Madrid, 1978, p. 26-27, lám. 8-10.

(334) Y. YADIN, Masada. La dernière citadelle d'Israël, Paris, 1966, p. 119-121, 124-125.

(335) A. Blanco Freijeiro, los mosaicos romanos de Merida, «Actas del Bimilenario de Merida», Madrid, 1976, p. 192-193, lám. XC. Para a evolução do tema: Pedro de Palol, Arqueologia Cristiana de la España Romana, Madrid, 1967, p. 254, flg. 90.

(336) V. Tzaferis, Jewish Tombs at and near Giv'at hi-Mivtar, «Israel Exploration Journal», 20, 1-2, 1970, p. 18-32, pi. 12-16; N. Avigad, The Burial-Vault of a Nazirite Family on Mount Scopus, «Israel Exploration Journal», 21, 4, 1971, p. 185-200, pi. 40-42.

Conimbriga, 21 (1982), 5-99 
origem, e significado culturais concretos a um tema de tão grande difusão geográfica e cronológica. A interpretação em termos decorativos de qualquer das formas da rosácea, como estilização floral ou simples ornato geométrico, naturalmente apoiada pelas suas características intrínsecas e pela forma repetitiva que assinala a sua inclusão em numerosos monumentos $\left({ }^{337}\right)$, quase resulta obrigatória ao ocorrer, mais uma vez sob uma forma considerada tipicamente céltica ( $\left.{ }^{338}\right)$, numa bimah da sinagoga israelita de Chorazin ${ }^{(339)}$. Desta forma, não nos parece prudente atribuir-lhe, ressalvando uma ou outra eventual utilização simbólica, um significado muito diferente daquele que reveste o uso predominante de motivos cruciformes entre os Tuaregue e nos tapetes argelinos

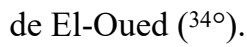

A dinâmica dos símbolos é complexa e a interpretação destes como tal, desconhecida a motivação criadora, extremamente arriscada: a runa Hagel, com os símbolos da vida e da morte entrelaçados, insígnia de duas divisões alemãs durante a Segunda Guerra Mundial (341), foi adoptada internacionalmente como emblema do Serviço de Ambulâncias.

\section{d) Datacão}

A ausência de consagração aos deuses Manes, o uso do nominativo e a indicação da idade ( ${ }^{342}$ ), são elementos que, aliados à simplicidade do conjunto, sugerem para esta inscrição uma data próxima do final do século i, sugestão não contrariada pela análise paleogràfica.

(337) Blázquez, Estudios, p. 433, fig. 158, 164.

${ }^{(338)}$ IGLESIAS, p. 138-139.

(339) M. AVI-YonAH, The Archaelogy of Israel, «Archaeology» (Israel Pocket Library), Jerusalém, 1974, p. 17.

${ }^{\left(34^{\circ}\right)}$ Attilio Gaudio, Les Civilisations du Sahara, Verviers, 1967, p. $74,179$.

(341) Duas unidades das Waffen SS; as divisões Nord e Polizei IL

(342) Thylander, p. 52.

Conimbriga, 21 (1982), 5-99 


\section{CONCLUSÕES}

A interpretação de material epigráfico como recurso para obter informações sobre a população antiga de uma determinada região revela-se sempre plena de dificuldades e continua a suscitar acentuado cepticismo ${ }^{(343)}$. Por isso mesmo e dado que o número de epígrafes conservadas no Museu está muito longe do mínimo considerado como podendo fornecer dados válidos acerca de uma cidade ou região restrita ${ }^{(344)}$, referiremos apenas alguns factores menos prejudicados pela extrema diversidade de formas e de textos — reflexo seguro de diferentes épocas e ambientes - verificada no material disponível.

O conjunto proporciona sete tipos diferentes: uma cupa (n. ${ }^{\circ} 1$ ), uma tampa de arca cinerària (.$\left.^{\circ} 12\right)$, duas placas $\left(n .^{\circ} 5,8\right)$, quatro esteias $\left(n .^{\circ} 9,10,11,13\right)$, dois cipos $\left(n .^{\circ} 2,3\right)$, dois pedestais $\left(n .^{\circ} 4,7\right)$ e uma ara (n. $\left.{ }^{\circ} 6\right)$. As esteias são, sem dúvida, obras produzidas localmente; outros monumentos, talhados num calcário lioz muito abundante em pedreiras do termo torriense, terão idêntica origem (n. $\left.{ }^{\circ} 1,2,3,5,6,8,12\right)$. Os vestígios de villae e os numerosos testemunhos epigráficos subsistentes, em grande parte relacionados com cidadãos, provam que os lapidarii dispuseram de uma clientela importante e potencialmente interessada nos seus trabalhos, factor necessário e suficiente para possibilitar o funcionamente de oficinas locais. Esta hipótese é praticamente confirmada pela semelhança tipológica entre a placa da Quinta do Juncai (n. ${ }^{\circ}$ 8) e a da igreja de Matacães (CIL II 278) e pelas numerosas irregularidades - nomeadamente de paginação_verificadas na maior parte das epígrafes. A determinação da origem dos grandes pedestais de Torres Vedras (n. ${ }^{\circ}$ 4) e da Quinta da Macheia $\left(n .^{\circ} 7\right)$ é, atendendo às suas características, mais complicada: sem desprezar a possibilidade de se tratar de trabalhos locais prefe-

(343) M. Chauss, Les iproblèmes de la statistique de l'âge d'après les inscriptions funéraires romaines, «Antiquités Africaines», 9, 1975, p. 109-113; Petit, p. 255-259.

(344) Clauss, p. 111.

Conimbriga, 21 (1982), 5-99 
rimos relacioná-los com oficinas do aro olisiponense; o material, calcário lioz, provirá então de Pero Pinheiro ou de Montelavar. Quanto aos textos, evidenciam, igualmente, geral falta de uniformidade. A fórmula de consagração aos deuses Manes, abreviada, ocorre apenas duas vezes: como DIS MANIBVS (n. $\left.{ }^{\circ} 12\right)$ e como D . M . (n. $\left.{ }^{\circ} 8\right)$. Os dedicantes nem sempre são familiares $\left(n{ }^{\circ} 3,7\right)$. $\mathrm{O}$ nome do defunto surge em nominativo (n. ${ }^{\circ} 1,2,5,7,9,13$ ), dativo $\left(\mathrm{n} .{ }^{\circ} 3,4,6,8\right)$ e genitivo $\left(\mathrm{n} .^{\circ} 10,11,12\right)$, A identificação dos indivíduos compreende filiação e tribo $\left(\mathrm{n} .{ }^{\circ} 2,4,5,7,8,12\right)$, filiação (n. $\left.{ }^{\circ} 1,6,7,12\right)$, filiação indicada pelos cognomina $\left(n .^{\circ} 9,10,11\right)$ e ausência de filiação (n. ${ }^{\circ} 3,4,8,13$ ). A idade é indicada oito vezes, precedida das abreviaturas ANN $\left(\mathrm{n} .^{\circ} 5,6\right)$ e $\mathrm{AN}\left(\mathrm{n} .^{\circ} 1,2,8,12\right)$ e da sigla A (n. $\left.{ }^{\circ} 13\right)$. H . S . E . encontra-se presente em três das epígrafes (n. $\left.{ }^{\circ} 1,2,13\right) ; \mathrm{H} . \mathrm{S} . \mathrm{S}$. uma vez (n. ${ }^{\circ}$ ); $\mathrm{S} . \mathrm{T} . \mathrm{T} . \mathrm{L}$. e EX T\{estamento) ocorrem apenas num dos pedestais monumentais (n. ${ }^{\circ} 4$ ), o mesmo se verificando com a expressão VIVA SE (n. ${ }^{\circ}$ 7). As fórmulas finais são menos matizadas: DE SVO FECIT (n. ${ }^{\circ}$ 12); $\mathrm{D}(\mathrm{c}) \mathrm{S}$ \{ao) $\mathrm{F}$ (ecit) (n. ${ }^{\circ}$ 1); $\mathrm{D}(\mathrm{c}) \mathrm{S}$ \{uo) F(aciendum) C(uravit) $\left(\mathrm{n} .^{\circ} 5,7,8\right)$. Quanto à ortografia há que referir XS por X (n. $\left.{ }^{\circ} 7\right)$, $\mathrm{V}$ por I antes de $\mathrm{M}$ (n. $\left..^{\circ} 6,7,12\right)$, assim como os nexos ER (n. $\left.{ }^{\circ} 4\right)$, ËT (n. $\left.{ }^{\circ} 6\right)$ MÃ (n. $\left.{ }^{\circ} 1,13\right)$, NT (n. $\left.{ }^{\circ} 3\right)$, TV (n. ${ }^{\circ}$ 9) e IF (n. ${ }^{\circ}$ )).

As inscrições conservadas no Museu apresentam uma certa coerência cronológica, proporcionando informações concretas sobre o estatuto social da população da zona de Torres Vedras nos séculos i e II : o núcleo engloba referências a cidadãos romanos (n. $\left.{ }^{\circ} 1,2,4,5,7,8,12\right)$, cidadãos latinos $\left(\mathrm{n}^{\circ} 3,6,13\right)$ e peregrinos $\left(\mathrm{n} .{ }^{\circ} 9,10,11\right)$, realçando paralelamente a desigual - ou inversa representação epigráfica dos vários corpos sociais representados. A determinação do estatuto económico deste heterogéneo grupo só pode fazer-se indirectamente; contudo, parece lógico atribuir a indivíduos dotados de meios razoáveis, senão importantes (n. ${ }^{\circ} 4$, 7, 12), a maior parte dos monumentos estudados. A percentagem dos antropónimos indiscutivelmente hispânicos - Arco, Boutia, Reburrus - é de 12,5\%; sem possibilitar uma interpretação exclusivamente étnica, exprime antes uma fase avançada do processo de integração entre os elementos indígenas e os elementos colonizadores romanos, parte dos quais relacionados com a África do Norte (n. $\left.{ }^{\circ} 2\right)$. Assim interpretada, e tendo em conta os factores 
específicos regionais e o maior horizonte cronológico do material epigráfico, não deixa de ser significativa a comparação com os valores proporcionados por Collipo, onde ascende a 35\%, e Évora, onde expressivamente desce para $1,6 \%$ (CIL II 119), $1,9 \%$ se abstrairmos das inscrições de Labéria Gala (CIL II 114) e de António Flavino (CIL II 115). Os testemunhos epigráficos, que incluem referências a divindades indígenas ( $\left.{ }^{345}\right)$, afirmam, muito naturalmente, a natureza céltica ou celtizada do fundo populacional do hinterland olisiponense $\left({ }^{346}\right)$, aliás profundamente influenciado pela proximidade de um dos principais centros urbanos da Lusitânia ( $\left.{ }^{347}\right)$ : na região de Torres Vedras, zona de vigorosa identidade cultural muito anterior à romanização, o elemento indígena reflecte-se de forma bem evidente nalgumas das epígrafes do Museu, quer na onomástica $\left(n .^{\circ} 4,7,9\right)$, quer na decoração (n. ${ }^{\circ}$ 9, 11, 13), ambas francamente relacionadas com o território hispânico de predominância céltica. O testemunho dos tria nomina não é menos relevante quanto à projecção regional de Olisipo e à forma como se difundiu no terreno a civilização romana ( $\left.{ }^{348}\right)$. Eis alguns valores expressos através da relação inscrições/referências, sugestivos uns, dramaticamente explícitos outros: núcleo regional do Museu Municipal de Torres Vedras (n. ${ }^{\circ}$ 2, 3, 4, 5, 6, 7, 8, 12, 13): $13 / 12$; lápidas dos arredores de Estremoz e de Eivas (349): 8/6; núcleo regional do Museu Municipal do Fundão (35०): 15/1; inscrições de Cantabria ( $\left.{ }^{351}\right)$ : 98/3. As sete referências à tribo Galéria registadas no material do Museu (n. ${ }^{\circ}$ 2, 4, 5, 7, 8, 12) constituem, como vimos (n. $\left.{ }^{\circ} 12\right)$, prova da integração da região

(345) José D'EnCarnaçâo, Divindades Indígenas sob o Dominio Romano em Portugal, Lisboa, 1975, p. 91-92, n. ${ }^{\circ}$ 7, p. 92-97, n. ${ }^{\circ}$ 8, p. 117-119, n, ${ }^{\circ} 15$, p. 206-208, n. ${ }^{\circ} 57$, p. 232-233, n. ${ }^{\circ} 72$, p. 310 (mapa).

(346) Lambino, Odrinhas, p. 165-173.

$\left({ }^{347}\right)$ Alarcão, Portugal, p. 65-68; D. Fernando de Almeida, Lisboa Romana e Visigótica, Lisboa, 1975, p. 6-13.

(348) Alföldy, Notes, p. 37-57. p. 69-73.

(349) EncarnaÇão, Inscriptions, p. 56-57; EncarnaÇão, Nordeste,

$\left(^{35 \circ}\right)$ J. L. YAz, Inscrições romanas do Museu do Fundão, «Conimbriga», XVI, 1977, p. 10-11.

(351) I GLESIAS, p. 217-225.

Conimbriga, 21 (1982), 5-99 
torriana no município olisiponense e permitem aflorar as relações económicas e sociais entre as grandes cidades e as comunidades rurais dependentes. $\mathrm{O}$ importante testemunho epigráfico dos municípios escalabitanos de Collipo,com cinco referências à tribo Quirina ( $\left.{ }^{352}\right)$, e de Conímbriga, apenas com três( $\left.{ }^{353}\right)$, confirmam nitidamente o real significado do índice torriense: as epígrafes estudadas rellectem uma situação determinada pela presença próxima da grande cidade do estuário do Tejo. Relacionadas com a minoria que queria e podia fazer inscrições, elas sugerem a existência, confirmada pelos materiais e pelas notícias recolhidas, de numerosas villae em torno de Torres Vedras ( $\left.{ }^{354}\right)$, decerto apoiadas no vasto mercado urbano olisiponense, facilmente acessível por via marítima, a partir do Sisandro $\left({ }^{355}\right)$, e, como parece, por estrada, da qual o possível trajecto a sul da região torriense foi esboçado por Estácio da Veiga (356). Os presumíveis proprietários das villae locais representavam, pelo menos parcialmente, a burguesia urbana olisiponense, inclusive o seu expoente político, a ordo decurionum (n. ${ }^{\circ}$ 12). A grande dispersão no terreno dos testemunhos epigráficos, e outros, pode explicar-se facilmente pela ausência de latifundia, dispersão que, como G. Mansuelli nota em relação à Cisalpina ${ }^{(357)}$, poderá provir de um diecismo de origem céltica. Por outro lado, a concentração cronológica das inscrições nos séculos i e n, que poderia sugerir uma explicação baseada na passagem do regime de villae ao regime de latifundia $\left({ }^{358}\right)$, concorda com a situação verificada nas restantes regiões do Império, rela-

(352) Pinho Brandẽo, p. 147.

(353) Fouilles, p. 57-58, n. ${ }^{\circ} 30$, p. 91-93, n. ${ }^{\circ} 70$, pi. XIV.

(354) o topónimo Torres Vedras poderá reflectir a implantação rural romana na região, uma vez que turris é sinónimo de villa, como se verifica no conventus escalabitano pela inscrição da villa de Cardílio, nos arredores de Torres Novas (ILER 2106). É possível, porém, que se trate de simples referência às fortificações locais.

(355) Orlando Ribeiro, Introduções Geográficas à História de Portugal, Lisboa, 1977, p. 106.

(356) Estácio da Veiga, Antiguidades de Mafra, Lisboa, 1879, p. 50-55.

(357) G. Mansuelli, I Cisalpini (3. sec. a. C.-3. sec. d. C.), Florença, 1962, p. 127-128, 141-144.

(358) M. Vigit, Historia de Espana Alfaguara, Madrid, 19*73, p. 358-367.

Conímbriga, 21 (1982), 5-90 
cionando-se com um facto cultural nascido com a Pax Romana e com ela desaparecido ( $\left.{ }^{359}\right)$.

Estamos muito mal informados sobre a economia regional na época romana. Os característicos entallaos abertos no pedestal da Quinta da Macheia (n. ${ }^{\circ}$ 7) favorecem a hipótese de uma reutilização romana como peso de lagar; sendo assim, teremos de admitir a existência de olivais nessa zona de solos calcários especialmente aptos para a cultura da oliveira. Os vestígios antigos-dolia, muros de cantaria e um pavimento lajeado - descobertos no século passado perto da ermida de S. Gião $\left({ }^{36^{\circ}}\right)$ parece indicarem também a presença de um lagar. As fontes literárias, infelizmente, náo ajudam a resolver o problema. Quanto às vinhas $\left({ }^{361}\right)$, sabemos, por um testemunho de Polibio, que já se cultivavam no sector meridional da Lusitânia por meados do século $\mathrm{n}$ a.C. ${ }^{362}$ ). Embora faltem provas directas, não parece arriscado considerar a viticultura, mais rentável que a cultura cerealífera e melhor adaptada às condições naturais da região, como uma das actividades básicas das villae torrienses, tanto mais que o problema, fundamental, do escoamento e comercialização, teria resposta adequada. A ara consagrada a Liber Pater, o deus protector dos vinhedos, encontrada em Lisboa (ILER 214), enquadra-se perfeitamente na hipótese esboçada, mesmo que a não consideremos como uma prova absoluta de actividades vitícolas.

As invasões do século $\mathrm{v}$ provocaram danos que nos escapam: a villa da Quinta de S. Gião, por exemplo, parece ter sobrevivido à efémera ocupação suévica $\left({ }^{363}\right)$.

No termo torriense, apesar da contribuição da epigrafîa, só a escavação permitirá localizar e interpretar com precisão os restos das villae e dos vici, enquanto a análise dos materiais regionais conservados nos museus e provenientes de descobertas fortuitas

(359) MrozeK, p. 117-118.

$\left(3^{\circ}\right)$ PINHO LEAL, IX, 1880, p. 662-663.

(361) VIGIL, p. 328.

(362) Poli i о, 34, 9: o rio Tejo constituía a fronteira sul da Lusitânia.

$\left({ }^{363}\right)$ BELO, «Badaladas», 83, 1953. O próprio orago sugere uma ocupação visigòtica: a ermida de S. Gião ilustra a persistência da villa romana como centro religioso, transformação exemplarmente patente em S. Miguel de Odrinhas. 
poderá fornecer informações francamente valiosas, tanto mais que a escavação de estações situadas pela maior parte, parafraseando André de Resende, «entre as vinhas de Torres Vedras», se revela dificilmente praticável. Até lá, teremos de considerar com prudência algumas das hipóteses enunciadas e aguardar a confirmação das conclusões extraídas do estudo das inscrições romanas do Museu Municipal de Torres Vedras (364), cidade nova de história velha, centro de uma região de paisagens suaves e luminosas a que Horácio não recusaria o seu tarentino angulus ridet.

(364) Agradecemos vivamente ao director do Museu Municipal de Torres Yedras e veterano da arqueologia torriense, Sr. Leonel Trindade, todas as informações prestadas e inúmeras facilidades concedidas para elaboração deste trabalho. As fotografias são da autoria de Delfim Ferreira e de Ezequiel Santos (n. ${ }^{\circ}$ ). Os mapas foram desenhados por Fernando Coroado. 


\section{ANEXO I \\ IVLIA AMOENA: TESTEMUNHOS EPIGRÁFICOS E SUA REPARTIÇÃO}

$\mathrm{i}-\mathrm{S}$. Giáo (Torres Vedras).

Iulia . L.f. Amoelna . an.XII.h.s.e/ma.d.s.f

BELO, «Badaladas», 62, 1952.

2 - S. Gião (Torres Vedras).

Iulia . C.f. Ton/ceta . aaa . XX/h.s.e. lidia . L.f./

/Amoena . mater/ $f$. c

CIL II $296=/$ LEÄ 4313.

3 - Cabeça (Sintra).

[/a/ia]a(?) . L .f. Amoena . h. s. ei [Cl]odius . P. f. Avitus .

aa . XX ./ 5 e/[...] ¿ws Civis h.s.e

CIL II 268 - ILE R 2402.

4 - Colares (Sintra).

Terentia . L .f. Maxumal mater . Iuliae . C.f. Amoenae / arm.

XXVII .h.s.e.s.t.t.l

CIL II 318 - 7LÆ/? 4286.

5 - Codieeira (Sintra).

/a/¿a. Ç.f. Am/oena.h.s.e

CIL II 5017 - 7L£7? 2405.

6 - Funchal (Sintra).

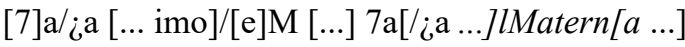

Cardozo, Catálogo, p. 75, n. ${ }^{\circ}$ LXVIII.

Conimbriga, 21 (1982), 5-99 
7 - Alapraia (Cascais).

[ V]itorius $G$ [ $f$. [Ga]l. Victor A.[s .] / [e. Iu]lia $G$. $f$. Amj[o]ena a.s.f.c.

EnCARnaÇão, Cascais, p. 102-104, n. ${ }^{\circ} 7$.

8 - Caparide (Cascais).

$[/ \wedge / i \mathrm{a}](?) \mathrm{G} . f$. Amo(ena) I h. s. e .

leg.XXII p. [f.]/f.c.

Avitas ; [ve]t.

EnCARnaÇ̃̃o, Cascais, p. 96-98, n. ${ }^{\circ} 4=I L E R 6387$.

9 - Idanha-a-Velha.

Iuliae I Varillae / Celeris $f[L$. lulius Qair / Modestus /

statuam / cum basis / $f$. $c$ i lidia Amoena / Sabini $f$. mater $j$ I auravit

Almeida, Egitânia, p. 200, n. ${ }^{\circ} 93$ - ILER 1772.

10 - Elvas.

D. M. S Ilulia. Amoenaj ann. XXXII j $h$. s . e. s .t.t.l/G . Pomponius / Maxumus . mari/tus . coniugi / carissimae . $f$. $c$ CIL II $156=\quad 4486$.

11-_Conceição (Ourique).

Iulia I Seili. f. / Amoena

EnCARnaÇão, Sudoeste, p. 44-45, n. ${ }^{\circ} 2$.

12 - Fronteira (Bensafrim).

C . Iulius! Arenius h.s.e. ¡Arbura Bolbi / Arem' uxor / h.s. [e. $] /[/]^{\wedge} / ¿$ a Amoena / Arem f. h.s.e .

ILER 6186.

13 - Reus (Tarragona).

[...] o/. Ingenuo . / [/i¿/¿]ae( ?) / St(ati). I. Amoe[mze $h.] m . h$. n. $s$.

RIT 914.

Conimbriga, 21 (1982), 5-99 


\section{POTITVS E FORMAS DERIVADAS: \\ TESTEMUNHOS EPIGRÁFICOS E SUA REPARTIÇÃO}

1 - - Torres Vedras

Q. Bovio Atim/etioni Victori / Q . B . Marciani / ann. $L X X \mid$

I Q . B . Potitus I patri optumo

inédito.

2 - Várzea do Douro.

Tameobrigo / Potitus / Cunteli / votum / patris / s . I. m

CIL II 2377.

3 - Abação (Guimarães)

[...] [S]ulpic[ius] I [...]\& . Po[titus]( ?)

CIL II 5555.

4 - Arroyo de la Luz (Cáceres)

B[...] evius[...]; viri annor/iim CVh.s.s./s. v. t. I. Poti/tus

Vecetis fdonatum / posit

ILER 6426.

5 - Mérida

Valeria C.f. Aunia; an. Lh.s.e.s.t.t.I. ; L. Iulius

C.f. Gai . Lupus an. XX A h.s.e.s.t.t.I./C. Iulius

Potitus / coniugi et f.f. c.

ILER 3666 - 6275.

6•-Cádis

Poti(tus); C. Vaze(m)

CIL II 4970 $399,6257^{150}$ (cerâmica). 
7 - Sevilha

D . Cutio . Balbino / M. Cornelio Potito / L . Attio . Iuniano $j$

I Romulo . Ill loir / ciar . cur andar / piissumo . filio / B albinus . pater / Prisca . mater

CIL II 1172.

8 -- Sevilha

D . M . $£$. IAelius Pot[it]/[i]anus vix[it] an. ;XXXII pius in [suos] / maritae / benemerenti] / fecit h.s.e.

ILER 3419.

9 - Adra (Almeria)

Martialis)Martialis . $f ;$ ann . XXIIPPotita . Martiaßis . $f$.

Carbo;nis . ann . XXI/hs $s$

CIL II 1990.

10 - Liria

Atiliae . M. $f$. Potijtae . Iunia . Tanne/gadinia . $p . n$. an . AA

CIL II 3796.

11 - Liria

Ç. Caecilio ; Q.f. Gal / Potito / Quintiliae . patronae CIL II 3799.

12 - Vivel

ilf. Aemilius ; $M . f$. G; Potitus . an [ $L V h . s . e$

CIL II 4006.

13 - Tarragona

Potiani I Potitia

CIL II 4970397 (cerâmica).

14 - Tarragona

Potiti

CIL II 4970398 (cerâmica).

15 - Tarragona

C. Caecilio / C.f. Gal. iPotito / Raecia Irene / filio ILER 4328.

16 - Amp úrias

Potiti $M[\ldots]$

CIL II $6257^{151}$ (cerámica).

Conímbriga, 21 (1982), 5-99 


\section{I - NOMINA VIRORVM ET MVLIERVM}

L. Anicius Optatus, 3.

M. Antistius Facundus, 7.

Attius Montanus, 3.

Q. Bovius Atimetio Victor, 6 .

Q. Bovius Marcianus, 6 .

Q. Bovius Potitus, 6.

Iulia, 5.

Iulia Amoena, 1.

Iulia Quintilia, 8.

Iulia Marcella, 12.

M. Iulius Crescens, 4.

M. Caecilius Avitus, 12.

Q. Iulius Fronto, 8.

Q. Caecilius Caecilianus, 12. Licinia Maxsuma, 7.

C. Caecilius Gaetulicus, 2.

L. Licinius Temporanus, 13.

Cornelia Boutia, 7.

L. Valerius Areo, 4.

\section{II — COGNOMINA VIRORVM ET MVLIERVM}

Amoena, 1.

Areo, 4.

Atimetio, 6.

Avitus, 12.

Boutia, 7.

Bovius, 11.

Caecilianus, 12.

Crescens, 4.

Facundus, 7.

Fronto, 8.

Gaetulicus, 2.

Macer, 10.

Marcella, 12.

\section{III —CIVITAS ROMANA}

Tribus

Galeria: 2, 4, 5, 7, 8, 12.

\section{Gentes}

Anicia: 3.

Antistia: 7.
Marcianus, 6.

Mascellius, 10.

Maxsuma, 7.

Montanus, 3.

Optatus, 3.

Potitus, 6.

Quintilia, 8.

Reburrus, 9 .

Rufus, 11.

Temporanus, 13.

Tusca, 11.

Tuscus, 11.

Victor, 6.

Attia: 3.

Bovia: 6.

Caecilia: 2, 12.

Cornelia: 7 .

Iulia: 1, 4, 5, 8, 12.

Licinia: 7, 13.

Valeria: 4.

IV — RES MVN ICI PALIS

Aedilis

C. Caecilius Caecilianus: 12.

Conimbriga, 21 (1982), 5-99 


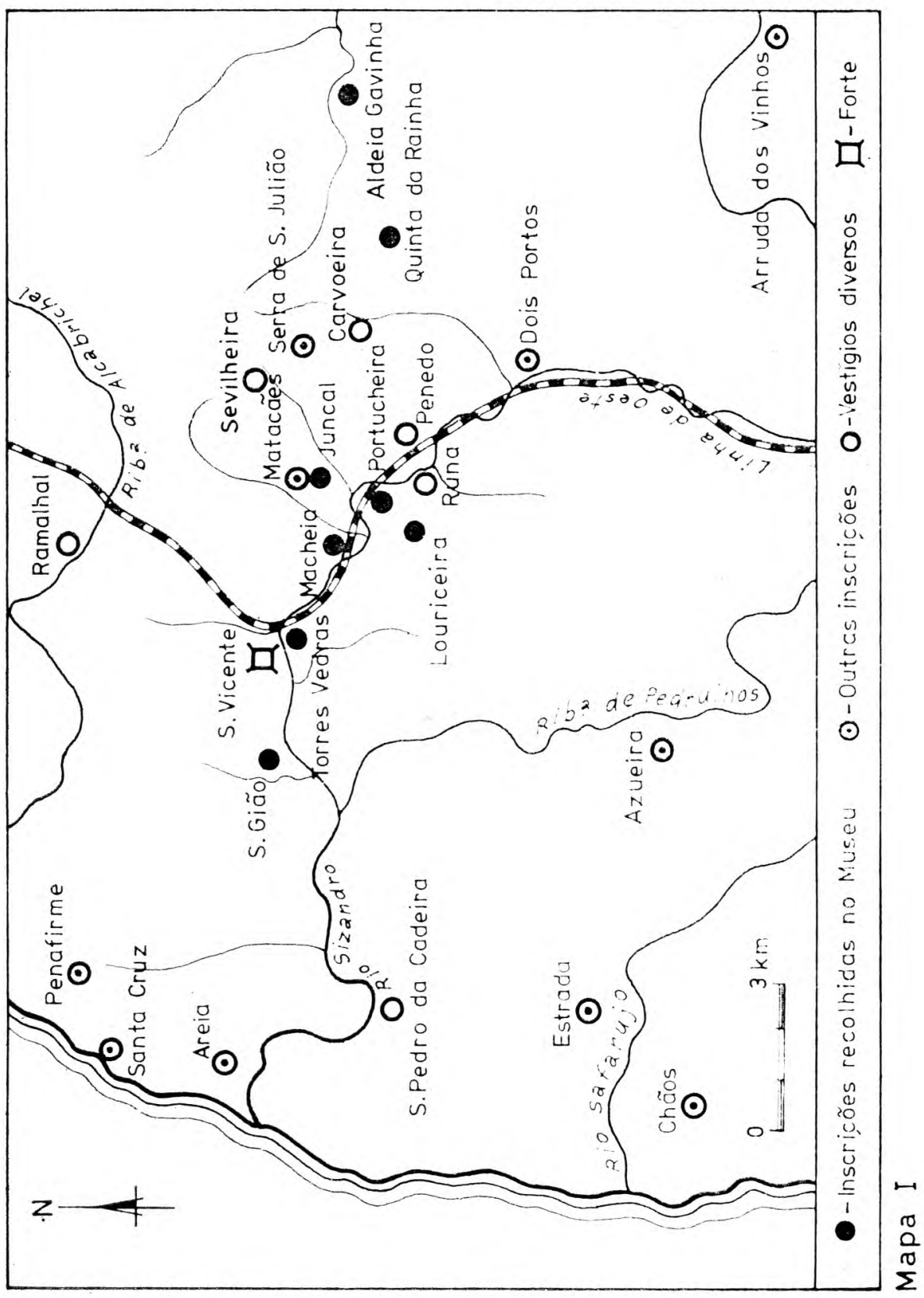


1-Torres Yedras: inédita.

2 -Lisboa: CIL II 4993, 4998.

3 - Cadafais (Alenquer): CIL II 288.

4 - Santarém: CIL II 329.

5 - Alfeizerão: CIL II 357.

6- Alcácer do Sai: CIL II 36.

7 - Évora: CIL II 5191; ENCARNAÇão, Évora. p. 83-85, n. ${ }^{\circ} 4$, p. 89-91, n. ${ }^{\circ} 6$.

8- S. Miguel da Mota (Alandroal) : CIL II 5207.

9-Mérida: CIL II 598 (?).

10 - Caparra (Cáceres) : CPIL 346.

11-Balsa (Luz de Tavira) : CIL I I 4989/5161.

12 - Itálica: CIL II 1110; HAE 569.

13 - Peñaflor (Sevilha) : CIL II 5539.

14 - Cartama (Málaga): CIL II 1951.

15 -Lucena: CIL II 1632.

16 - Bujalance (Córdova) : CIL II 496740.

17-Maquiz (Jáen): CIL II 5067.

18 - Linares: CIL II 3308.

19 -Elche: CIL II 5953.

20 - Játiva: CIL II 3623.

21-Sagunto: CIL II 3841.

22 - Onda: CIL II 4035.

23 - Tarragona: CIL II 4118, 4122/4259, 4182, 6111; RIT 398, o89.

24 -Peñalba de Castro (Burgos): CIL II 2807.

25 - Villalís (Leão): ILER 24. 


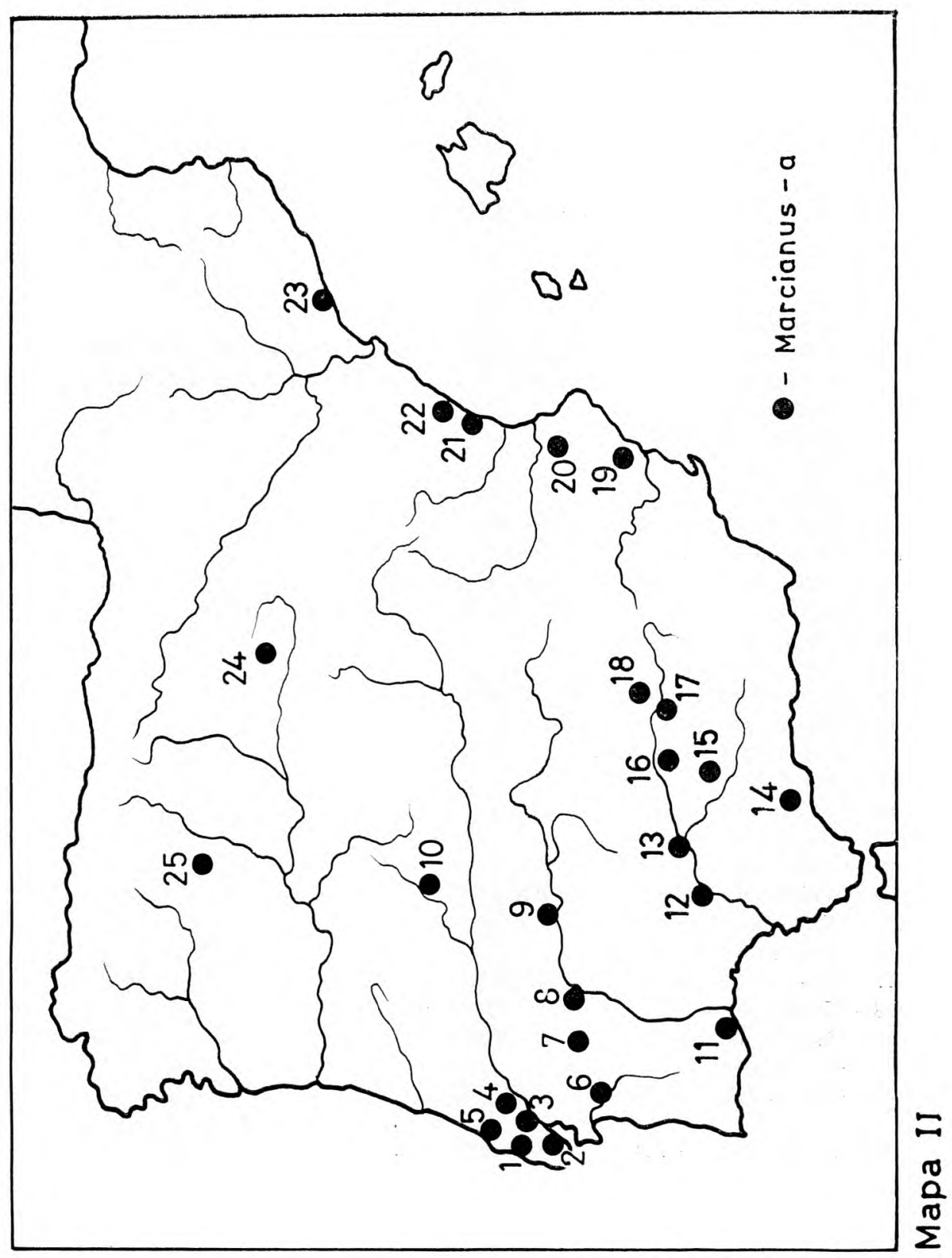




\section{LEGENDA DO MAPA III}

1-Antistiana: ILER 1779.

2 - Quinta da Macheia (Torres Vedras) ; BeLo, «Badaladas», 230, 1959 $=$ «Conimbriga», I, 1959, p. $157=$ ALMEIDA/FERREIRA, Varia, LXXVI, 1966, p. 341-343.

3 - Lisboa: CIL II 4996.

4 - Tentúgal: $C I L$ II 395.

5 - Coria: CIL II 792.

6-Valdelacasa (Cáceres); ILER 967.

7 - Escurial (Cáceres) : ILER 2685.

8 - Valdelacasa de Tajo (Cáceres) : CPIL 583.

9 - Mérida: CIL II 599; ILER 557, 4185; Martin, p. 232-233.

10-Olivença: CIL II 1023.

11 - Pias: ILER 3356.

12 - Frejenal de la Sierra: CIL II 975.

13- Monasterio: CIL II 1042.

14 -Cordova: CIL II 2242.

15 - Porcuna: CIL II 2139.

16 - Toya: CIL II 3330.

17 - Ecija: CIL II 5454.

18-Viana del Bollo: CIL II 2523.

19 - Villaverde (Santander): ILER 5852.

20_Villanañe (Burgos): CIL II 2922.

21-Sasamón: CIL II 5812.

22 - Las Cuevas (Soria): CIL II 2840.

23 - Torres (Alcalá de Henares): CIL II 3046(?).

24 - Região de Sagunto: CIL II 4034.

25 - Santañy: CIL II 3672-3674.

26 -Tarragona: CIL II 4324; RIT 507.

Não cartografado — Bética (?): Callender, 803, p. 148. 


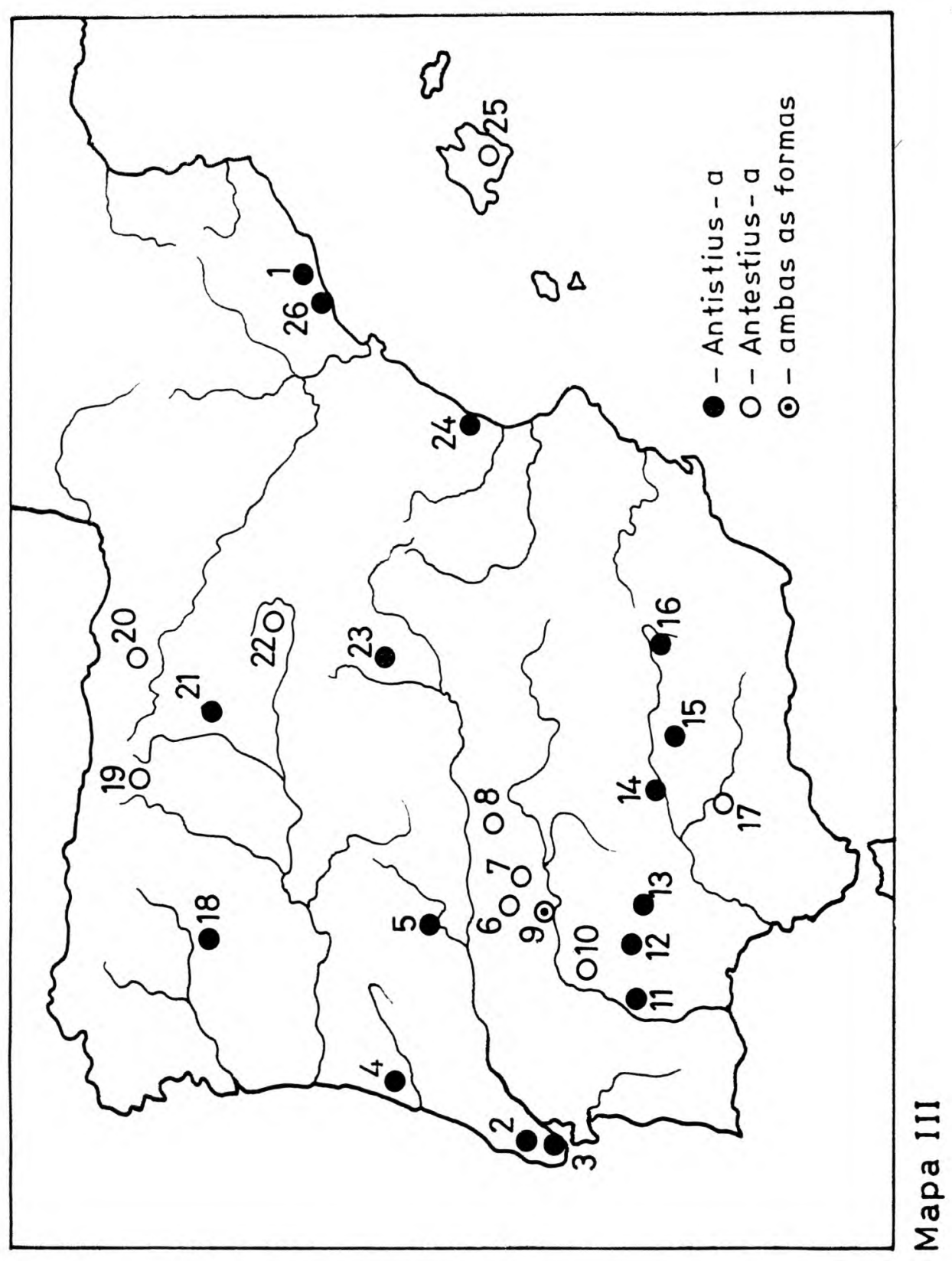


(Página deixada propositadamente em branco) 


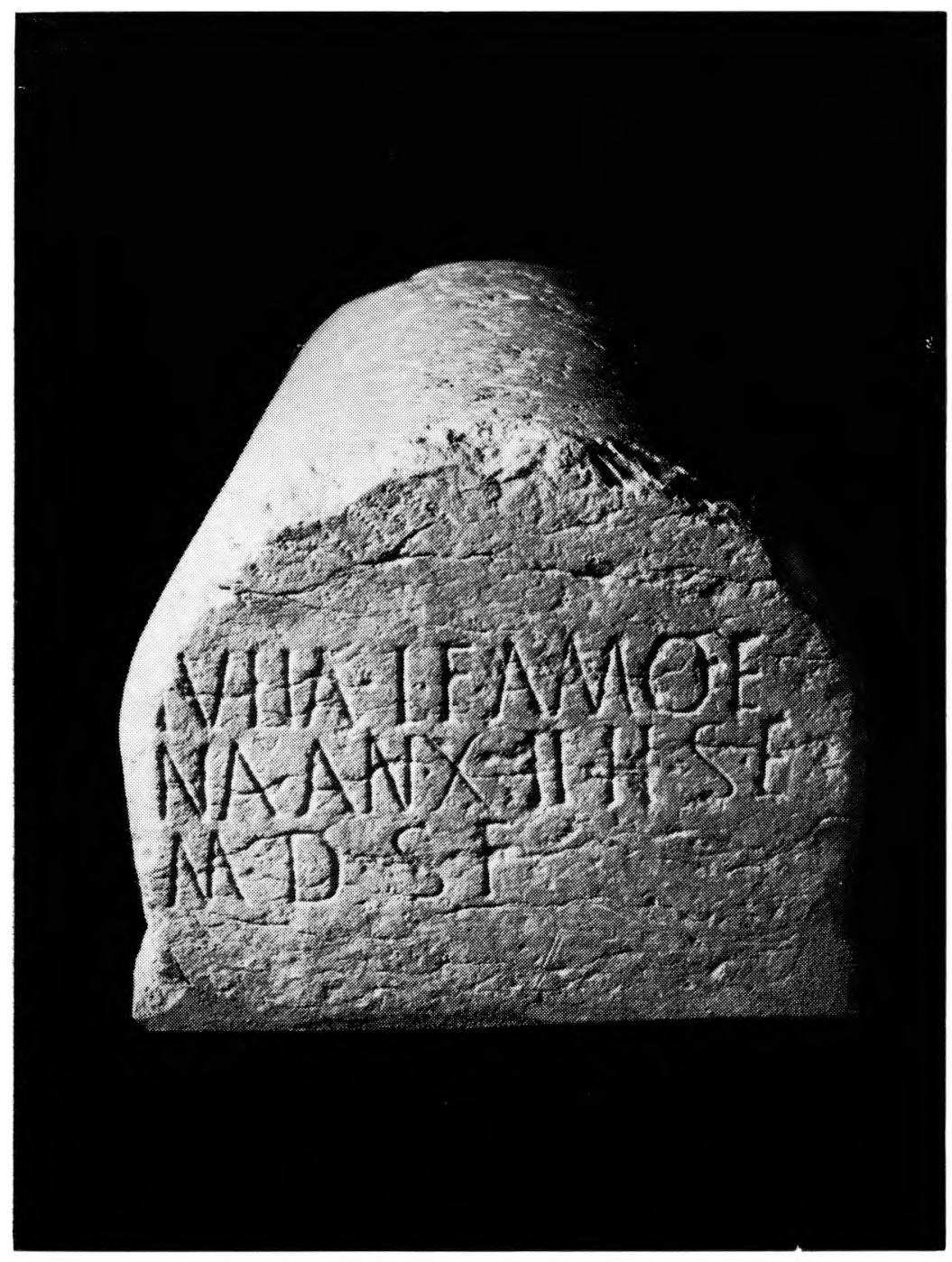

Inscrição n. ${ }^{\circ}$ 1. Foto 1 


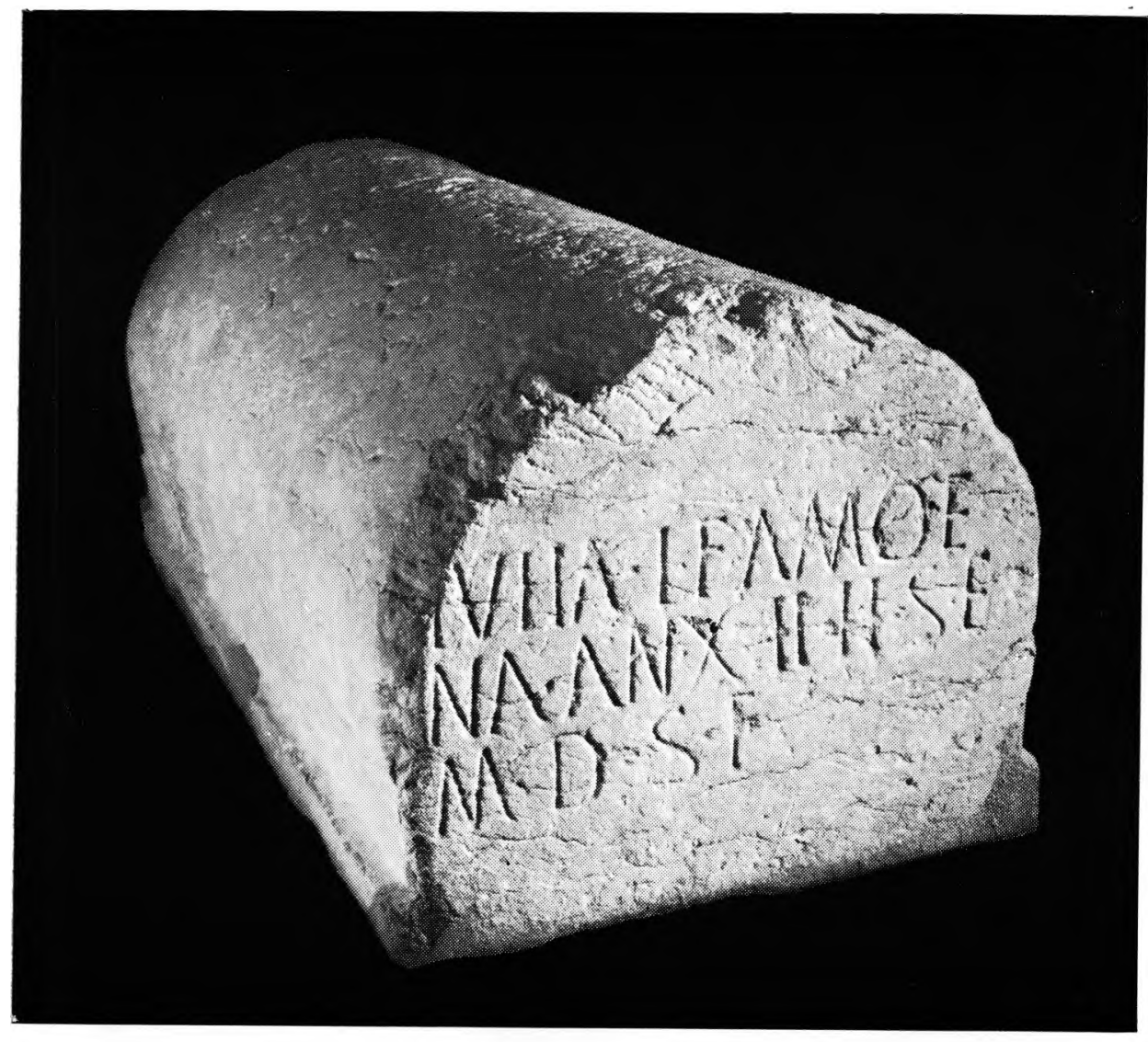

Inscrição n. ${ }^{0}$ 1. Foto 2 


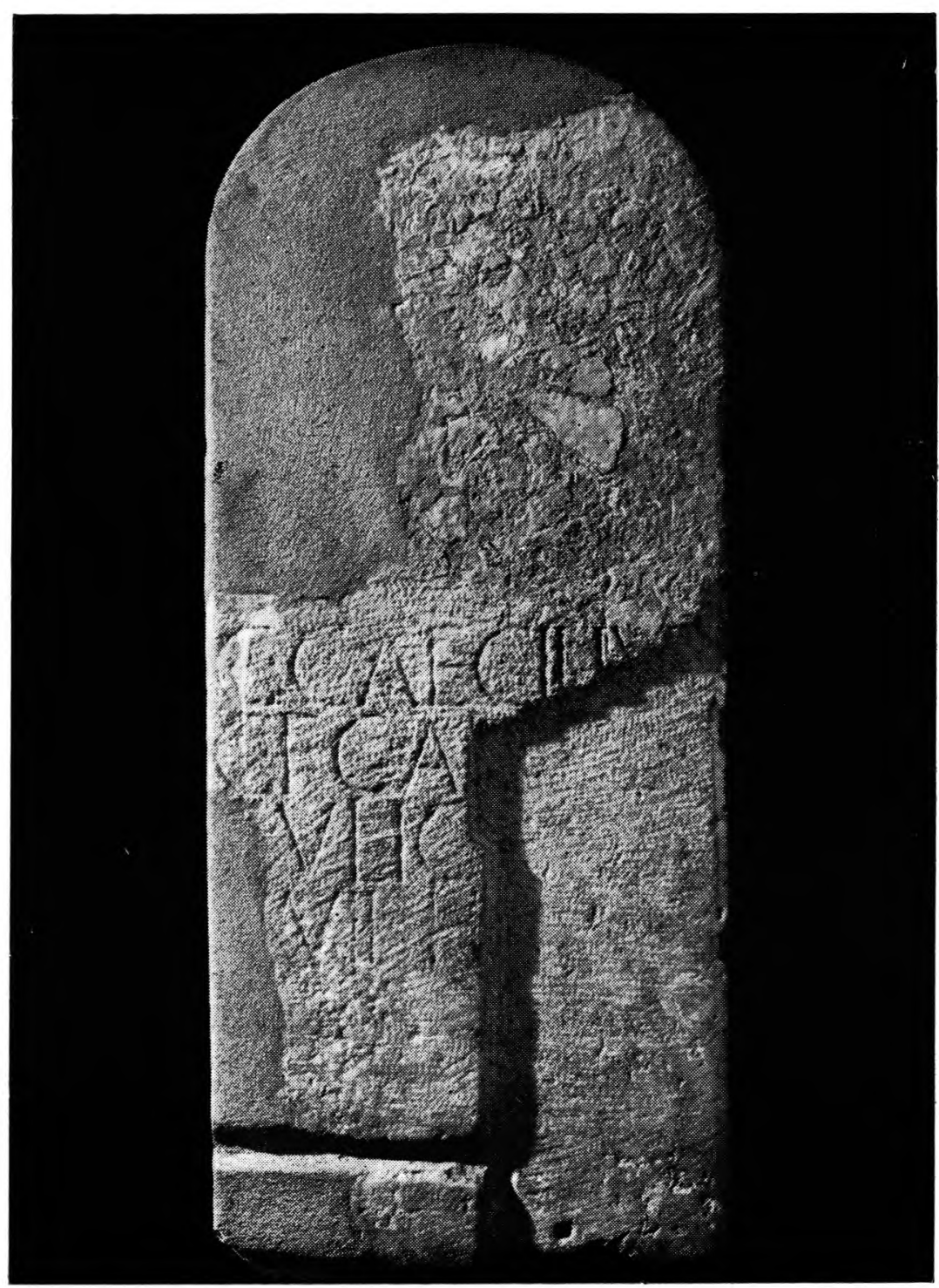

Inscrição n.o 2 . Foto 3 


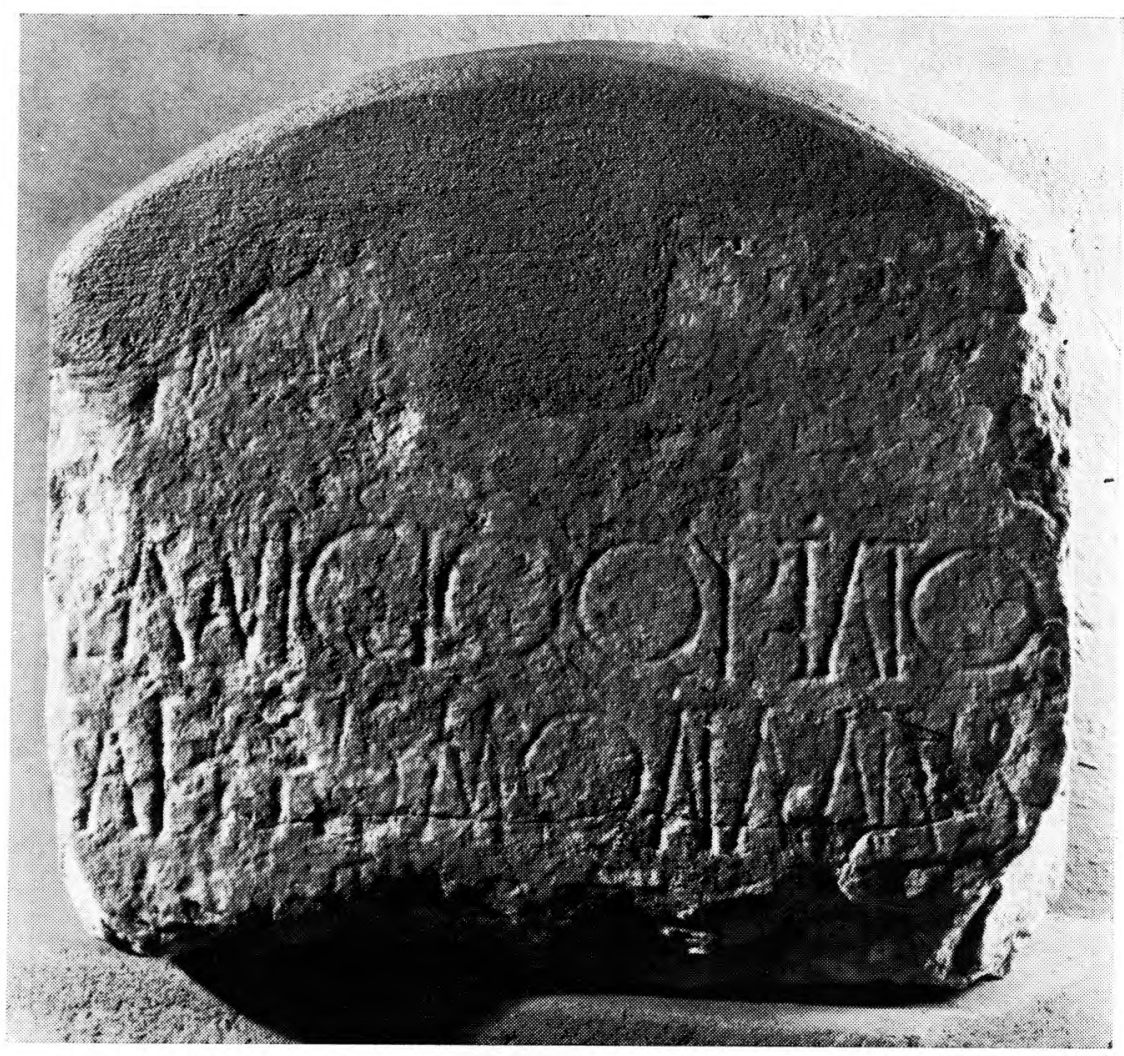

Inscrição n. ${ }^{\circ} 3$. Foto 4 


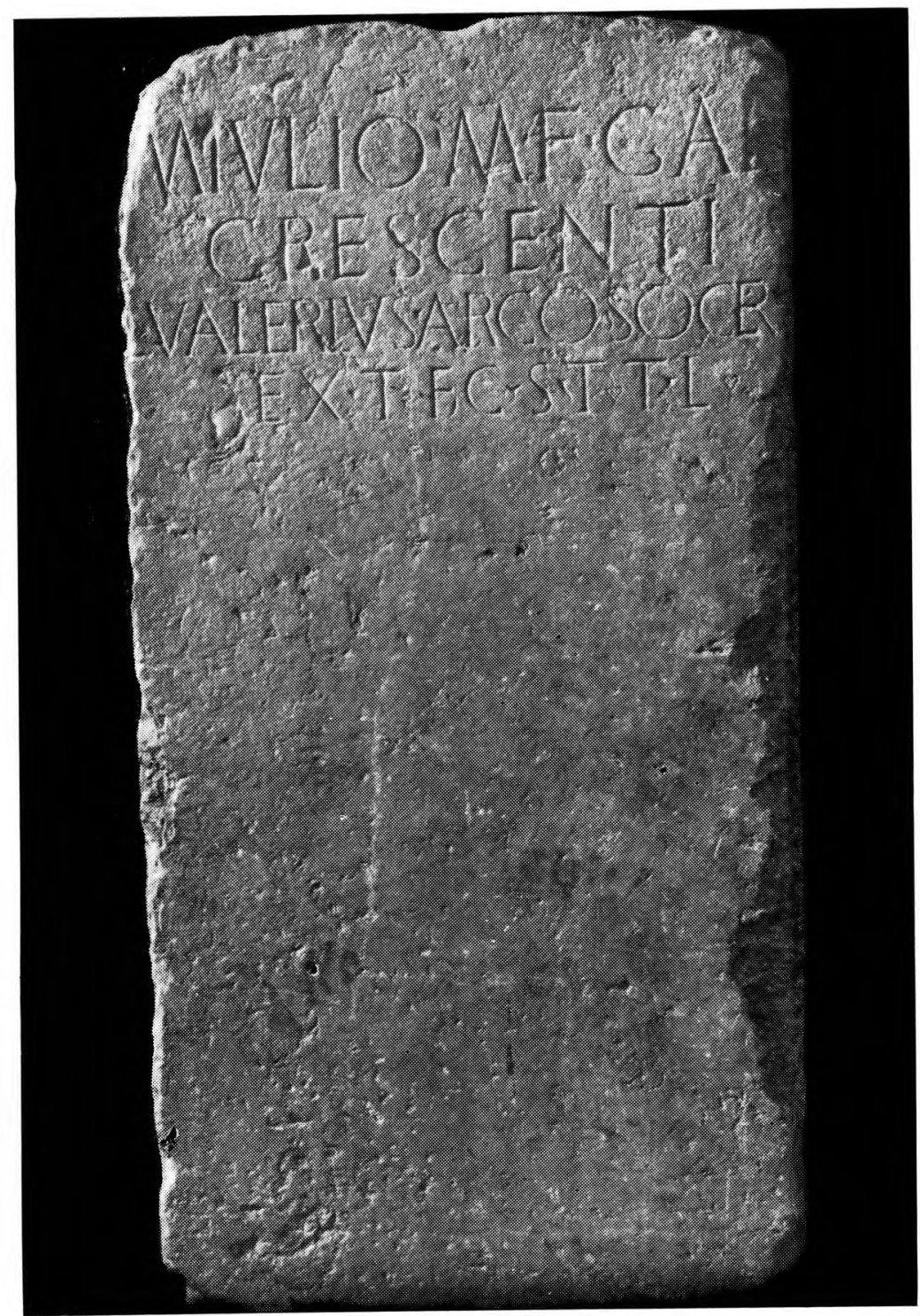

Inscrição n. ${ }^{0}$ 4. Foto 5 


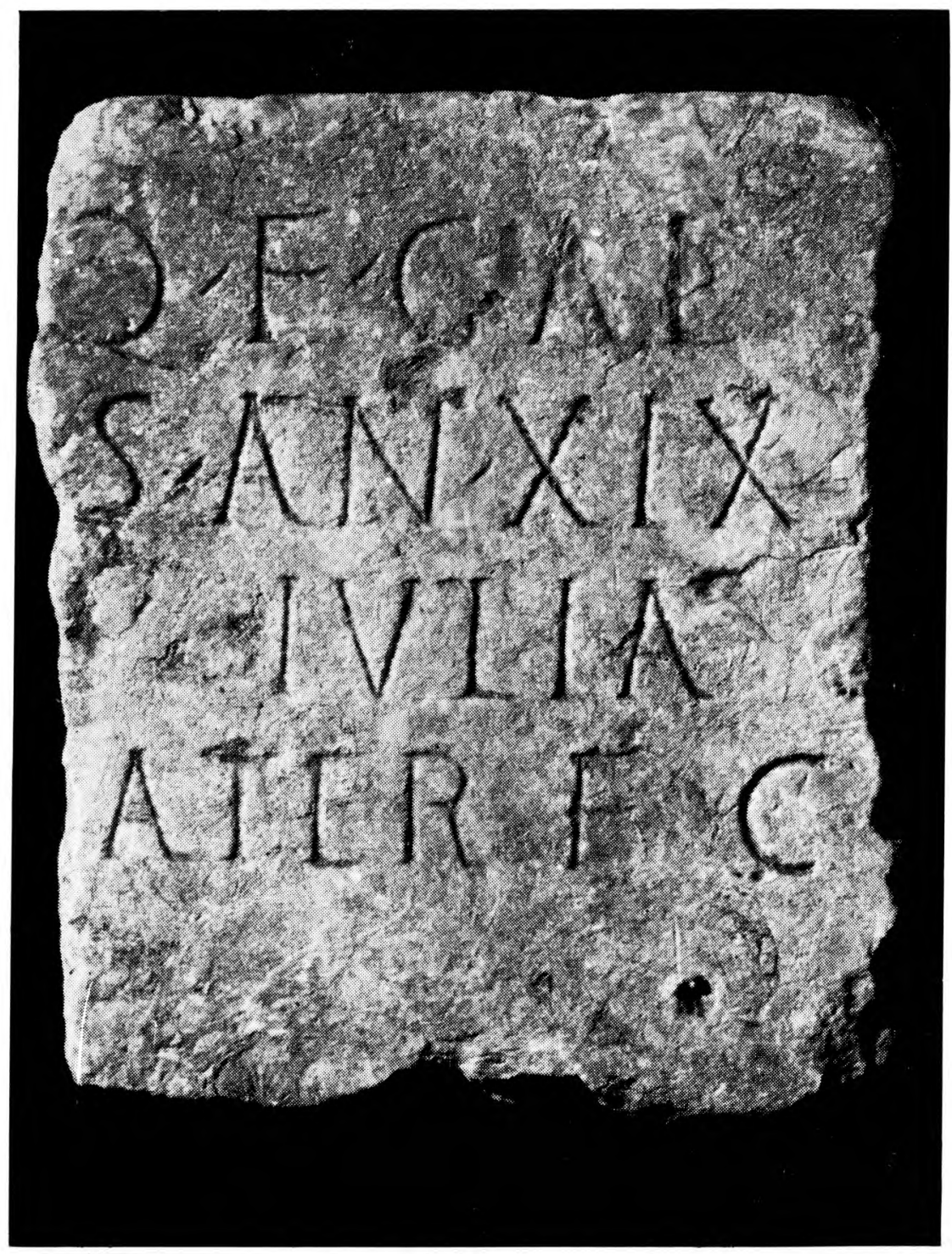

Inscrição n. ${ }^{0}$ 5. Foto 6 


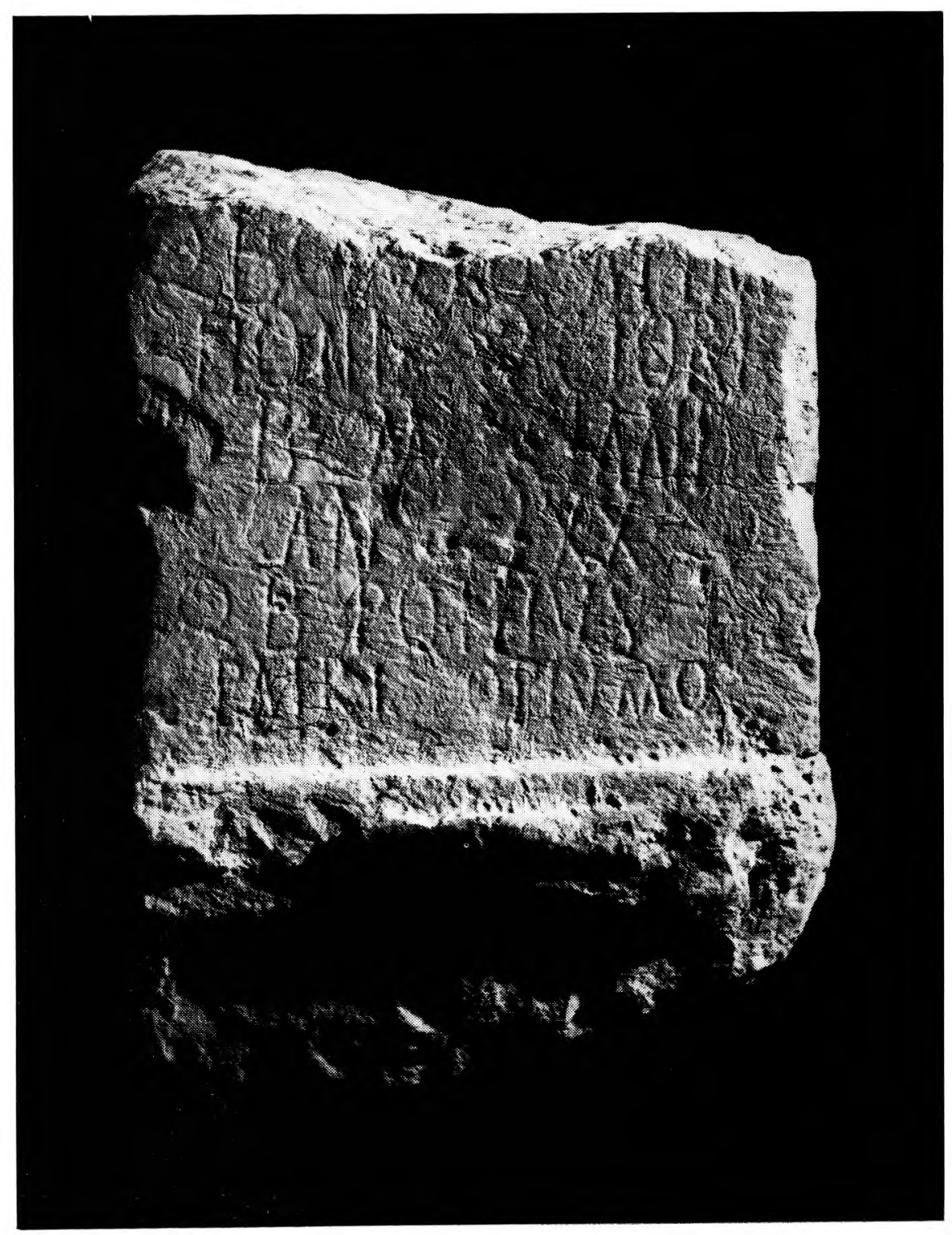

Inserição n.0 6. Foto 7 


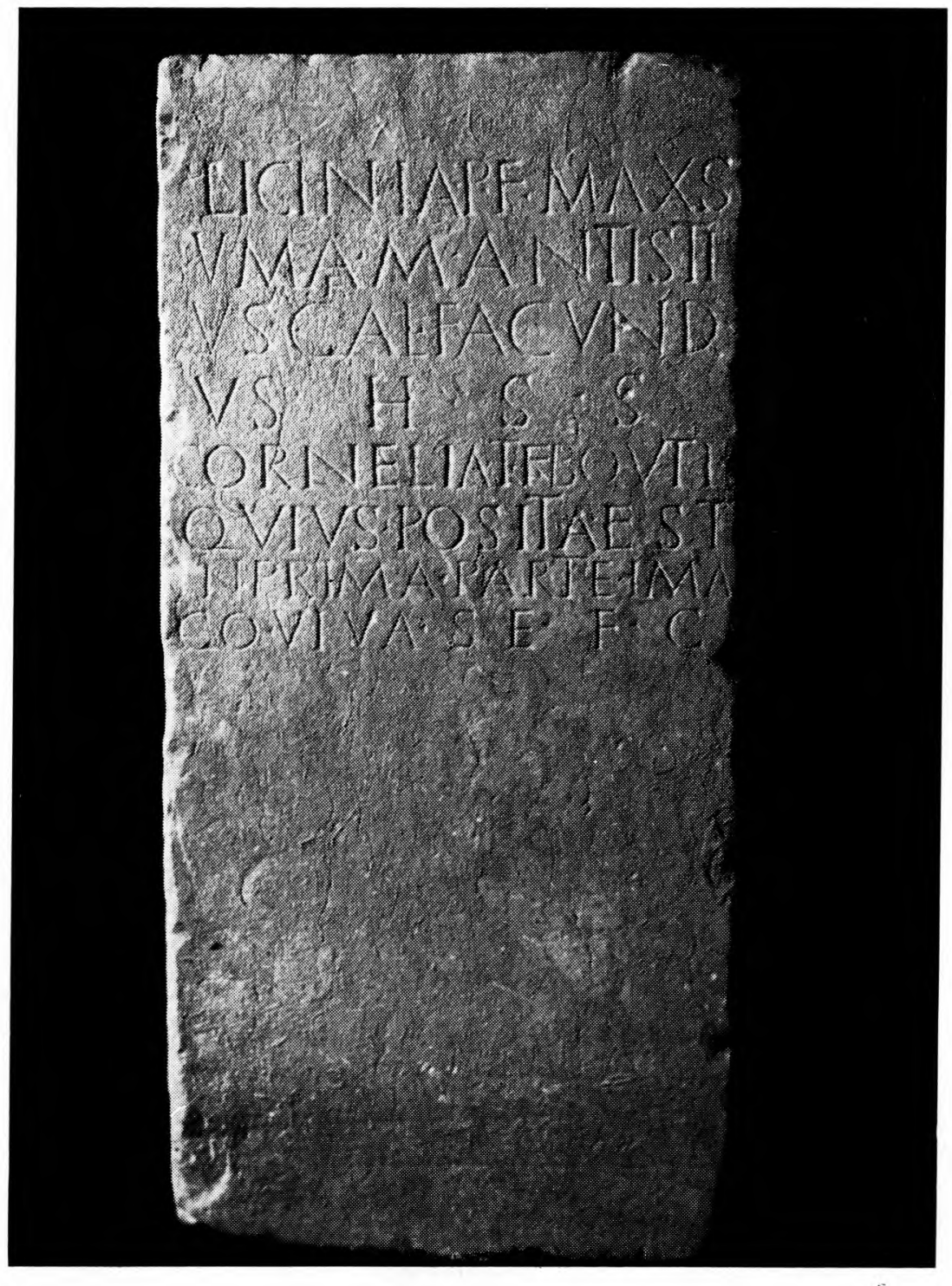

Inscrição n. ${ }^{0} 7$. Foto 8 


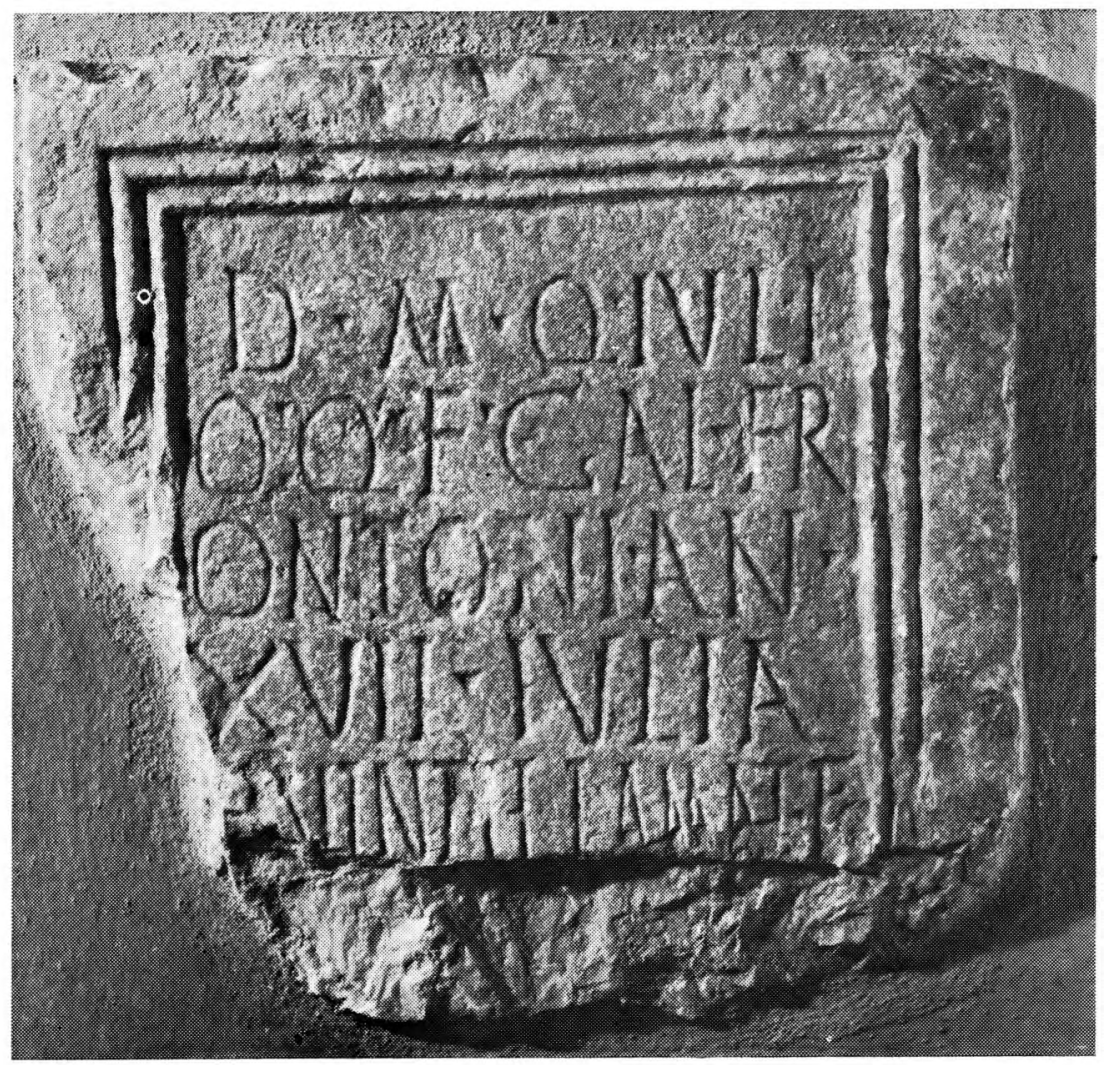

Inscrição n. ${ }^{\circ}$. Foto 9 


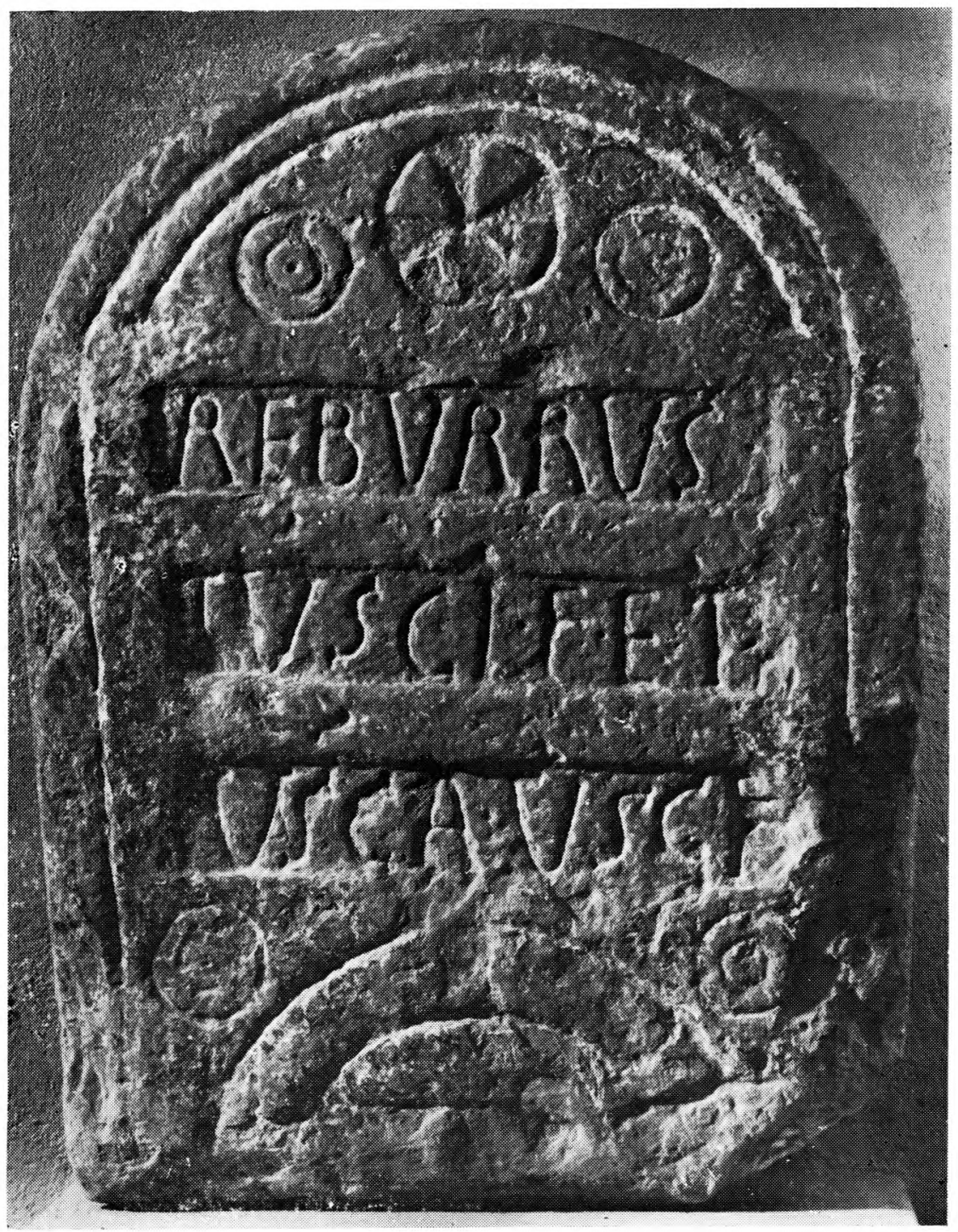

Inscrição n. ${ }^{\circ}$ 9. Foto 10 


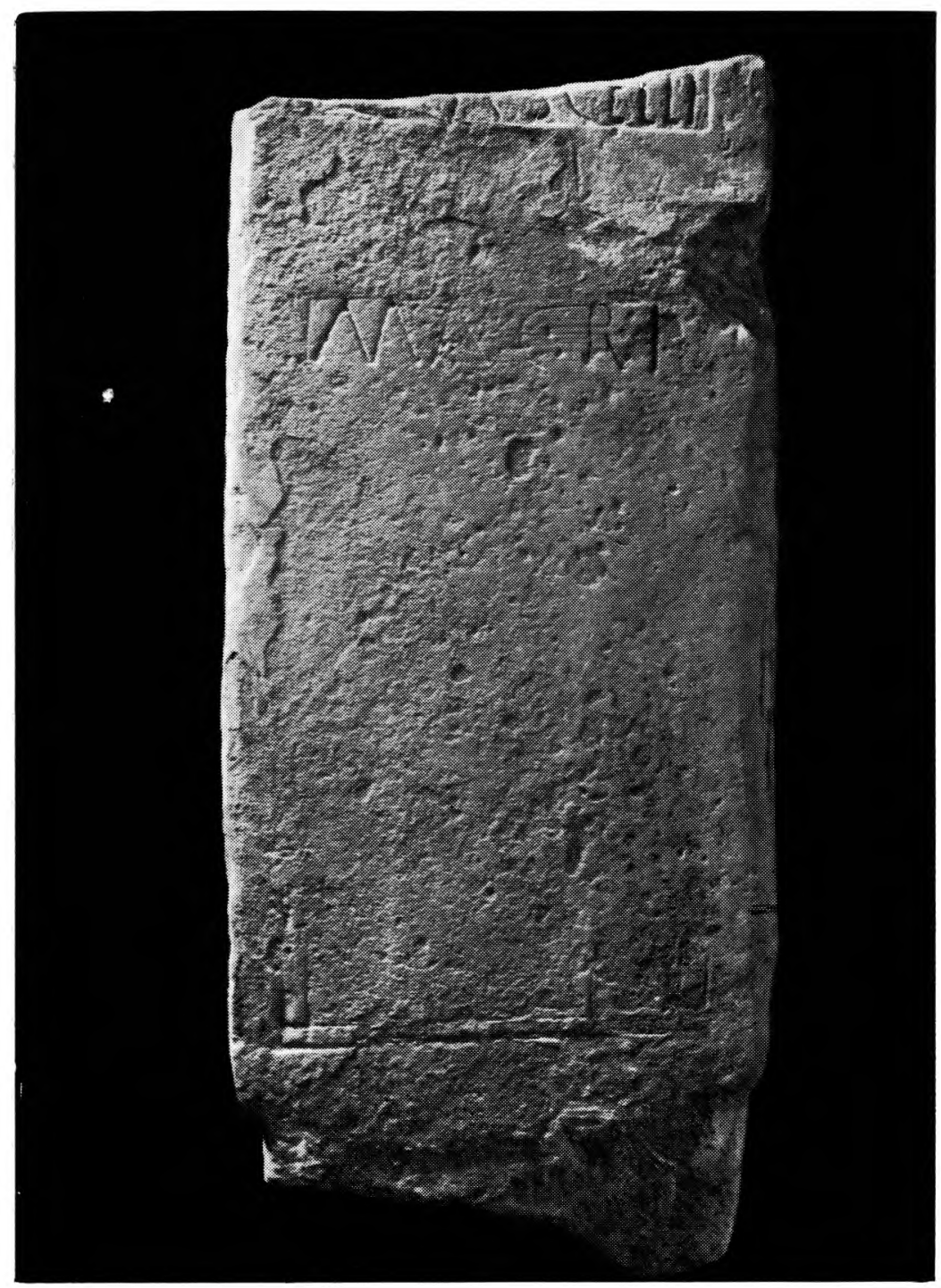

Inscrição n. ${ }^{0}$ 10. Foto 11 


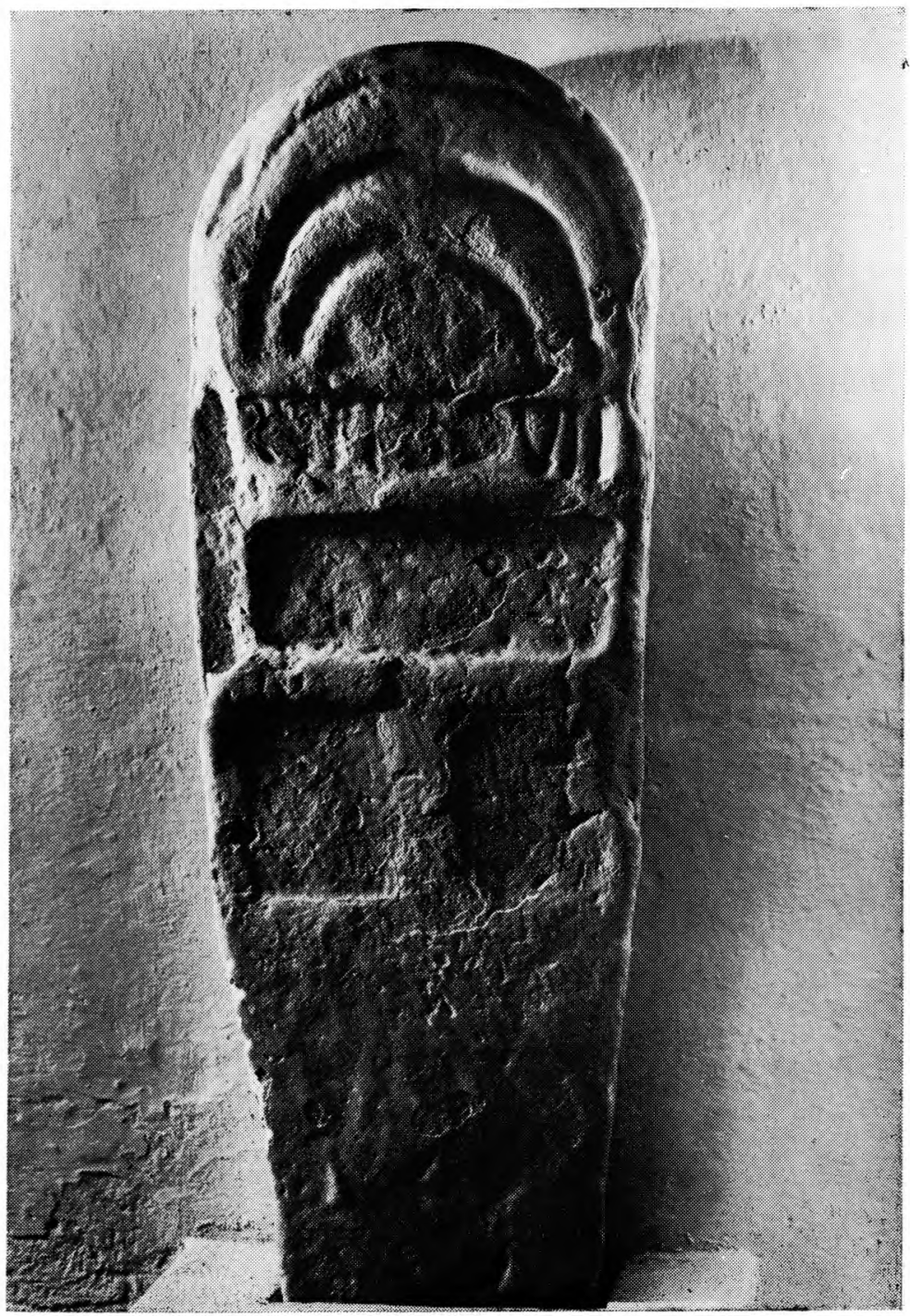

Inscrição n. ${ }^{\circ}$ 11. Foto 12 


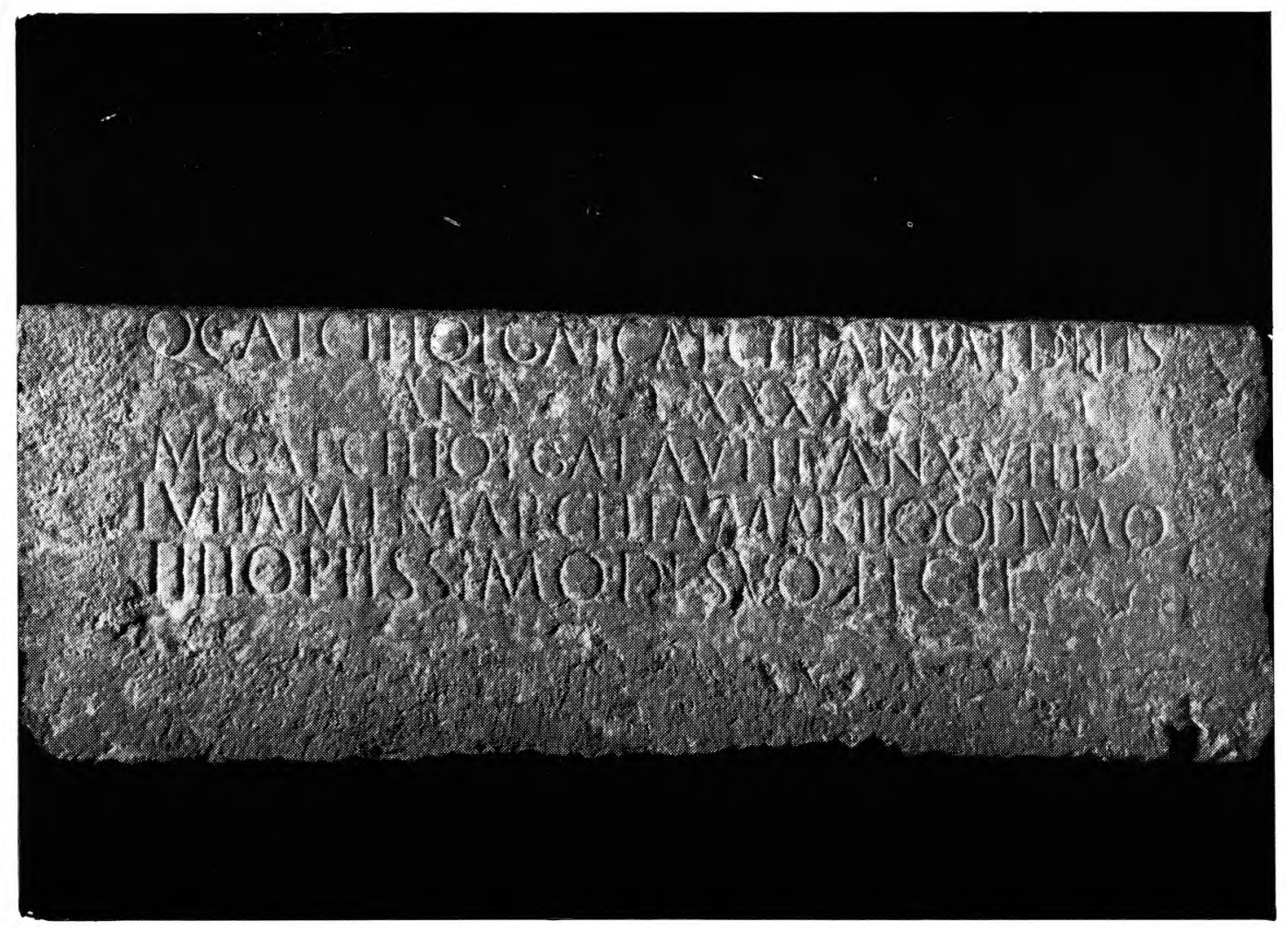

Inscrição n. ${ }^{\circ}$ 12. Foto 13 


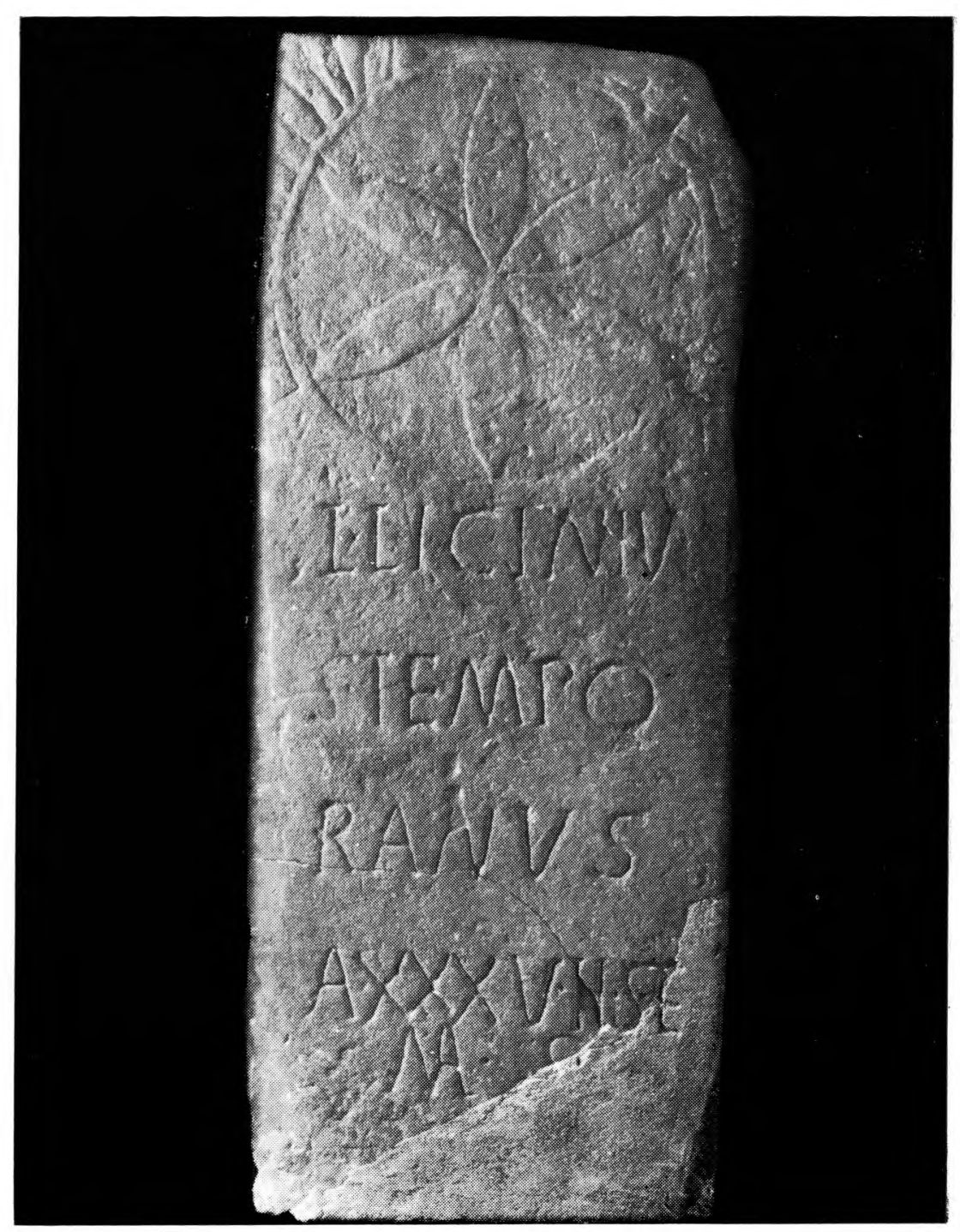

Inscrição n. ${ }^{\circ}$ 13. Foto 14 